\title{
ENGINEERING ASSESSMENT OF
}

INACTIVE URANIUM MILL TAILINGS

\author{
BELFIELD SITE \\ BELFIELD, NORTH DAKOTA
}

NOVEMBER 1981

PREPARED FOR

UNITED STATES DEPARTMENT OF ENERGY

ALBUQUERQUE OPERATIONS OFFICE

URANIUM MILL TAILINGS

REMEDIAL ACTIONS PROJECT OFFICE

ALBUQUERQUE, NEW MEXICO

CONTRACT NO. DE-AC04-76GJ01658

BY

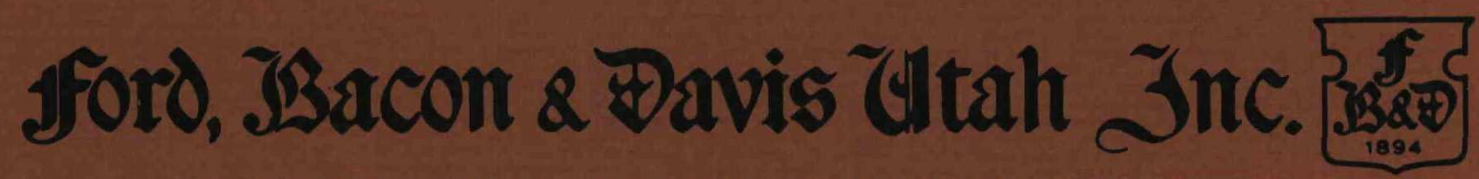

375 CHIPETA WAY, SALT LAKE CITY, UTAH $84108801583-3773$

SINCE 1894 


\section{DISCLAIMEB}

THIS REPORT WAS PREPARED AS AN ACCOUNT OF WORK SPONSORED BY THE UNITED STATES GOVERNMENT. NEITHER THE UNITED STATES NOR THE UNITED STATES DEPARTMENT OF ENERGY, NOR ANY OF THEIR EMPLOYEES, MAKES ANY WARRANTY, EXPRESS OR IMPLIED, OR ASSUMES ANY LEGAL LIABILITY OR RESPONSIBILITY FOR THE ACCURACY, COMPLETENESS, OR USEFULNESS OF ANY INFORMATION, APPARATUS, PRODUCT, OR PROCESS DISCLOSED, OR REPRESENTS THAT ITS USE WOULD NOT INFRINGE PRIVATELY OWNED RIGHTS. REFERENCE HEREIN TO ANY SPECIFIC COMMERCIAL PRODUCT, PROCESS OR SERVICE BY TRADE NAME, MARK, MANUFACTURER OR OTHERWISE, DOES NOT NECESSARILY CONSTITUTE OR IMPL'Y ITS ENDORSEMENT, RECOMMENDATION, OR FAVORING BY THE UNITED STATES GOVERNMENT OR ANY AGENCY THEREOF. THE VIEWS AND OPINIONS OF AUTHORS EXPRESSED HERE DO NOT NECESSARILY STATE OR REFLECT THOSE OF THE UNITED STATES GOVERNMENT OR ANY AGENCY THEREOF. 


\section{DISCLAIMER}

This report was prepared as an account of work sponsored by an agency of the United States Government. Neither the United States Government nor any agency Thereof, nor any of their employees, makes any warranty, express or implied, or assumes any legal liability or responsibility for the accuracy, completeness, or usefulness of any information, apparatus, product, or process disclosed, or represents that its use would not infringe privately owned rights. Reference herein to any specific commercial product, process, or service by trade name, trademark, manufacturer, or otherwise does not necessarily constitute or imply its endorsement, recommendation, or favoring by the United States Government or any agency thereof. The views and opinions of authors expressed herein do not necessarily state or reflect those of the United States Government or any agency thereof. 


\section{DISCLAIMER}

Portions of this document may be illegible in electronic image products. Images are produced from the best available original document. 
DOE/UMT-0122

FBDU -360-21

UC $70 A$

ENGINEERING ASSESSMENT

OF INACTIVE URANIUM MILL TAILINGS

BELFIELD SITE

BELFIELD, NORTH LAKOTA

November 1981

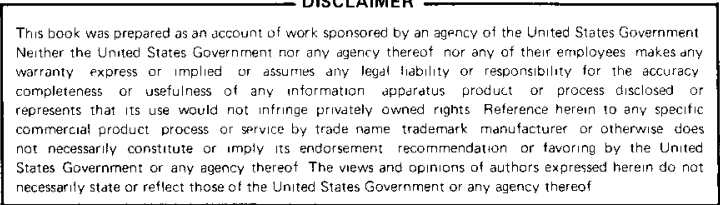

Prepared for

U.S. DEPARTMENT OF ENERCY

ALBUQUERQUE OPERATIONS OFFICE

URANIUM MILL TAILINGS REMEDIAL ACTIONS PROJECT OFFICE

ALBUQUERQUE, NEW MEXICO

Contract NO. DE-ACO4-76GJO1658

By

FORD, BACON \& DAVIS UTAH INC.

375 Chipeta way

Salt Lake city, Utain 84108 
NOTICE

This engineering assessment has been performed under DOE contract iNo. DE-ACO4-7GGJUl658 between the U.S. Department of Energy and Ford, Bacon \& Davis Utah Inc.

Copies of this report nay be ubtained from the Uranium Will Tailings Remedial Action Project office, U.S. Department of Eneryy, Alouquerque operations office, Albuquerque, New liexico 37115. 
FOREIVIRD

The U.S. Department of tinergy (LUL), Alouquerque Operations Office, Jranium Mill Tailings Remedial Action Project Office, Albuquerque, New viexico, has authorized Ford, Bacon \& Davis Utah Inc. to submit an engineering assessment of the lignite ashiny site at Belfield, Norti Dakota. The necessary work effort and resultant engineeriny assessment report are duthorized under Contract No. DL-AC04-76GJO1658.

This report presents inportant enyineeriny and environmental information gathered from many federal, state, and local sources. This inforruation is essential to assess the impacts associated with the options suggested for remedial actions for the contaminated resilues from the former ashing operations at the Belfield site. Although the report may at times refer to uranium mill tailings, the information is also relevant to the contaminated materials on the Belfield site.

Ford, Bacon \& Davis Utah Inc. has received excellent cooperation and assistance in obtaining the data necessary to prepare this report. Special recognition is due Richard $\mathrm{H}$. Campbell and Mark Matthews of DOE, as well as personnel of the Burlington Jorthern kailroad Company, the present owner of the Belfield site, and of the L.P. Anderson Construction Company. 


\section{ABSTRACT}

Ford, Bacon \& Davis Utah Inc. has evaluated the Belfield site in order to assess the problems resulting from the existence of radioactive ash at Belfield, South Dakota. This engineering assessment has included drilling of boreholes and radiometric measurements sufficient to determine areas and volumes of ash and radiation exposures of individuals and nearby populations, the investigations of site hydrology and meteorology, and the evaluation and costing of alternative corrective actions.

Radon gas released from the 55,600 tons of ash and contaminated material at the Belfield site constitutes a significant environmental impact, although external gamma radiation also is a factor. The four alternative actions presented in this engineering assessment range from millsite and off-site decontanination with the addition of $3 \mathrm{~m}$ of stabilization cover material (Option I), to removal of the ash and contaminated materials to remote disposal sites, and decontamination of the Belfield site (Options II through IV). Cost estimates for the four options range from about $\$ 1,500,000$ for stabilization in-place, to about $\$ 2,500,000$ for disposal at a distance of about $17 \mathrm{mi}$ from the Belfield site.

Reprocessing the ash for uranium recovery is not feasible because of the extremely small amount of material available at the site and because of its low $\mathrm{U}_{3} \mathrm{O}_{8}$ content. 
Notice. . . . . . . . . . . . . . . . . . . . . . ii

Foreword. . . . . . . . . . . . . . . . . . . ii

Abstract. . . . . . . . . . . . . . . . . iv

List of Figures. . . . . . . . . . . . . . . . ix

List of Tables. . . . . . . . . . . . . . . . . xi

SUMMARY . . . . . . . . . . . . . . . . . 1 . 1

1.1 Introduction . . . . . . . . . . . . . . 1-1

1.1 .1 Background. . . . . . . . . . . 1-2

1.1.2 Scope of Phase II Engineering

Assessment. . . . . . . . . . . 1-4

1.2 Site Description . . . . . . . . . . 1-6

1.2.1 Location and Topography . . . . . . 1-6

1.2.2 Ownership and History of Milling

Operations and Processing • . . . . 1-6

1.2.3 Present Condition of the Site. . . . 1-7

1.2.4 Contamination and Soil

Characteristics . . . . . . . . 1-7

1.2 .5 Geology, Hydrology, and
Meteorology . . . . . . . . . 1-7

1.3 Radioactivity and Pollutant Impacts
on the Environment . . . . . . . . . 1-8

1.3.1 Radiation Exposure Pathways,

Contamination Mechanisms, and

Background Levels... . . . . 1-9

1.3.1.1 Radon Gas Diffusion and

Transport. • • • • . • . 1-9

1.3.1.2 Direct Gamma Radiation . . 1-10

1.3.1.3 Windblown Contaminants . . 1-10

1.3.1.4 Surface and Ground water

1.3 .1 .5 Soil Contamination . . . . . 1-10

1.3.2 Remedial Action Criteria. . . . . . 1-11

1.3.3 Potential Health Impact . . . . . . 1-12

1.3.4 Nonradioactive Pollutants... . . 1-15

1.4 Socioeconomic and Land Use Impacts . . . . 1-15

1.5 Recovery of Residual Values. . . . . . . . 1-15

1.6 Mill Tailings Stabilization. . . . . . . . 1-15 
TABLE OF CONTENTS (Cont)

1.7 Off-Site Remedial Action . . . . . . . I-16

1.8 Disposal Site Selection. . . . . . . . . . . 1-17

1.9 Remedial Actions and Cost-Benefit

Analyses . . . . . . . . . . . . . . . 1-17

1.9.1 Remedial Action Options . . . . . 1-17

1.9.2 Cost-Benefit Analyses . . . . . . . . 1-18

Chapter 1 References. . . . . . . . . . . . 1-23

SITE DESCRIPTION. . . . . . . . . . . . 2-1

2.1 Location . . . . . . . . . . . . . 2-1

2.2 Topography . . . . . . . . . . . . . . 2-1

2.3 Ownership. . . . . . . . . . . . . . . . . . 2-2

2.4 History of Operations and Processing . . . 2-2

2.5 Present Condition of the Site. . . . . . . . 2-3

2.6 Tailings and Soil Characteristics. . . . . 2-3

2.7 Geology, Hydrology, and Meteorology. . . . 2-4

2.7 .1 Geology . . . . . . . . . . . . . 2-4

2.7.2 Surface Water Hydrology . . . . . 2-5

2.7 .3 Ground water Hydrology. . . . . . 2-6

2.7 .4 Meteorology . . . . . . . . . 2-8

Chapter 2 References. . . . . . . . 2-18

3 RADIOACTIVITY AND POLLUTANT IMPACT ON THE

ENVI RONMENT . . . . . . . . . . . . . . . . . . 3-1

3.1 Radioactive Material Characteristics . . . 3-1

3.2 Radiation Effects. . . . . . . . . . . . 3-2

3.3 Natural Background Radiation ... . . . 3-3

3.4 Radiation Exposure Pathways and

Contamination Mechanisms . . . . . . 3-3

3.4.1 Radon Gas Diffusion and Transport . . 3-4

3.4.2 Direct Gamma Radiation. . . . . . 3-5

3.4.3 Windblown Contaminants. . . . . 3-5

3.4.4 Ground and Surface Water Contamination . . . . . . . . 3-5

3.4.5 Soil Contamination. . . . . . . . 3-6

3.4.6 Off-Site Use of Contaminated

Material. . . . . . . . . 3-6

3.4.7 Radon Daughter Concentrations . . . 3-6

3.5 Remedial Action Criteria . . . . . . 3-7 
TABLE OE CONTENTS (Cont)

3.5.1 EPA Interin and Proposed

Standards... . . . . . . . . 3-7

3.5.2 NRC Regulations on Uranium Mill

Tailings. . . . . . . . . . . . 3-8

3.6 Potential Health Impact. . . . . . . . 3-10

3.6.1 Assumptions and Uncertainties in

Estimating Health Effects . . . . . . $3-10$
3.6.2 Health Effects. . . . . $3-12$

3.7 Nonradioactive Pollutants. . . . . . . 3-14

Chapter 3 References. . . . . . . . . . 3-30

4 SOCIOECONOMIC AND LAND USE IMPACTS. . . . . . . 4-1

4.1 Socioeconomic Background . . . . . . . . 4-1

4.2 Population Estimates . . . . . . . . . . 4-1

4.3 Land Use......... . . . . . . . . 4-3

4.4 Impact of the Contaminated soil on

Land Values. . . . . . . . . . . 4-3

Chapter 4 References. . . . . . . . . . . 4-10

5 RECOVERY OF RESiduAl VAlUes . . . . . . . . . . . 5- I

6 StABILIZATION OF CONTAMINATED MATERIALS . . . 6-1

6.1 Prevention of Wind and Water Erosion . . . 6-1

6.1.1 Surface Stabilization . . . . . .6-2

6.1.2 Volumetric Stabilization. . . . . 6-3

6.1.3 Physical Stabilization. . . . . . 6-4

6.1.4 Vegetative Stabilization. . . . . 6-5

6.2 Prevention of Leaching . . . . . . . . 6-6

6.3 Reduction of Radon Exhalation. . . . . . 6-7

6.4 Reduction of Gamma Radiation . . . . . . . 6-8

6.5 Assessment of Applicability. . . . . . . 6-8

Chapter 6 References. . . . . . . . . . 6-13

7 OFF-SITE REMEDIAL ACTION. • • • • • • • • • • • 7-1

7.1 Data Sources . . . . . . . . . . 7-1 
7.2 Remedial Action for Off-Site Properties Other Than Winablown . . . . . . . . . . 7-1

7.3 Remedial Action for off-Site Windblown Properties . . . . . . . . . . . . 7-1

DISPOSAL SITE SELECTION • . . . . . . . . . . 8-1

8.1 Criteria for Disposal. . . . . . . . . 8-1

8.2 Descriptions of Disposal Sites

Considered as Options. . . . . . . . . 8-2

8.2.1 Uranium Pit in Township 140

North, Range 99 West, Section 6 --

Site 3 (Option II). . . . . . . 8-4

8.2.2 Scoria Pits in Township 139

North, Range 99 West, Section 1 --

Site 7 (Option III) . . . . . . . . 8-4

8.2.3 Uranium Pit in Township 137

North, Range 100 West, Section 2 --

Site 8 (Option IV). . . . . . . 8-5

Chapter 8 References. . . . . . . . . . 8-8

9 REMEDIAL ACTIONS AND COST-BENEFIT ANALYSES. . . 9-1

9.1 Stabilization of the Contaminated

Materials on Site with a 3-Meter Cover

(Option I) . . . . . . . . . . . 9-2

9.1.1 Conceptual Design . . . . . . . 9-2

9.1.2 Costs... . . . . . . . . . 9-3

9.2 Removal of the Contaminated Materials

from the Site (Options II through IV). . . 9-3

9.2.1 Excavation and Loading of

Contaminated Materials and Soils. . 9-4

9.2.2 Transportation of the Materials . . 9-4

9.2.3 Disposal at Alternative Sites . . . 9-5

9.3 Analyses of Costs and Benefits . . . . . 9-6

9.3.1 Health Benefits . . . . . . . 9-6

9.3.2 Land Value Benefits . . . . . . . 9-7

GLOSSARY . . . . . . . . . . . . . . . G-1 
2-1 Aerial Photograph of Site . . . . . . . . . 2-10

2-2 Area Descriptive ivap. . . . . . . . . . . . 2-11

2-3 Site Descriptive Map. . . . . . . . . . . . 2-12

2-4 Stratigraphic column. . . . . . . . . . . 2-13

2-5 Flood Prone Areas . . . . . . . . . . . 2-14

2-6 Location of Wells Near Belfield. . . . . . . 2-15

3-1 Radioactive Decay Chain of Uranium-238. . . . . 3-15

3-2 Background Soil Sample Locations. . . . . . . 3-16

3-3 Radon Canister Locations and Flux Values. . . . 3-17

3-4 Gamma Levels at Site 3 Ft Above Ground. . . . . 3-18

3-5 Windblown Contamination Survey. . . . . . . . 3-19

3-6 Surface and Ground Water Sample Locations . • . 3-20

3-7 Radiometric Profile at Drill Hole BFND-19. • . . 3-2l

3-8 Radiometric Profile at Drill Hole BFND-22 . . . 3-22

3-9 Working Level Locations . . . . . . . . . . 3-23

Reduction of Outdoor 222 Rn Concentration
with Distance from Edge of Ashing Site. . . . . 3-24

3-11 Lung Cancer Risk from Continuous Exposure

4-1 Population Projections. . . . . . . . . . . 4-5

4-2 Vicinity Land Use . . . . . . . . . . . . 4-6

4-3 Market Value of Land. . . . . . . . . . . . 4-7

Exponential Moisture Dependence of the
Diffusion Coefficient. . . . . . . . . . . 6-10

Reduction of Radon Exhalation Flux with
Depth of Cover. . . . . . . . . . . . . . - . 11 


\section{LIST OF FIGURES (Cont)}

Number

Title

$\underline{\text { Page }}$

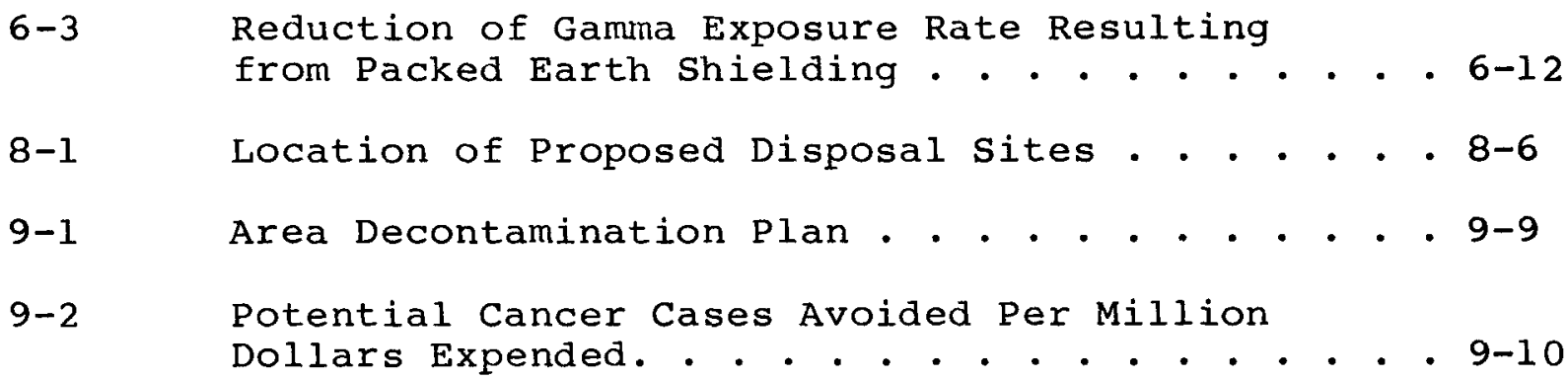




\section{LIS'T OF TABLES}

Number

Title

$\underline{\text { Page }}$

1-1 Summary of Conditions Noted at Time of 1980 Site Visits. . . . . . . . . . . . . 1-19

1-2 Summary of Remedial Action Options and Effects... . . . . . . . . . . . . . . 1-21

2-1 Estimated Quantities of Contaminated Materials.... . . . . . . . . . . . 2-16

2-2 Frequency of Wind Direction and Speed Dickinson, N.D. Municipal Airport (Period: 1955-1967). . . . . . . . . . 2-17

3-1 Notations anä Abbreviations Used in Chapter 3 . . . . . . . . . . . . . 3-26

3-2 Surface and Ground water Sample Results . . . . 3-28

3-3 Estimated Health Impact from Belfield Ash for an Area 0 to 2 Miles from Edge of the Site... . . . . . . . . . . . 3-29

4-1 Population History of Belfield and stark County. . . . . . . . . . . . . . . 4-8

4-2 Estimated 1980 Population Distribution. . . . . 4-9

8-1 Sites Evaluated for Disposal of the Contaminated Materials from the Former Belfield Lignite-Ashing Plant . . . . . . . 8-7

9-1 Summary of Stabilization and Disposal Costs... . . . . . . . . . . . . . 9-11

9-2 Potential Cancer Cases Avoided and Cost Per Potential Case Avoided. . . . . . . . . 9-12 
CHAPTER 1

SUIIARY 
CHAPTER 1

SUMMARY

\subsection{INTRODUCTION}

The U.S. Energy Research and Development Administration (ERDA) contracted in 197 b with Ford, Bacon \& Davis Utah Inc. (FB\&Du) of salt Lake city, Jtah, to provide architectengineering services and final reports based on the assessment of the problems resulting from the existence of large quantities of radioactive uranium mill tailings at inactive millsites in eight western states and in pennsylvania. In 1900, the U.S. Department of thergy (DOE) contracted with rB\&DU to produce revised reports of the sites designated in the Uranium Mill Tailings Remedial Action (UMRA) program in order to reflect the current conditions, new criteria and options, and to estimate current remedial action costs.

A preliminary survey (Phase I) was carried out in 1974 by the U.S. Atomic Lnergy Conmission (ALC) in cooperation with the U.S. Environmental Protection Agency (EPA) and the artected states. In a summary report, (I) EKDA identified 17 sites in Arizona, Colorado, Idaho, New Mexico, Utah, and Wyoming for which practical remedial measures were to be evaluated. subsequently, ERDA added five additional sites (Riverton and Converse County, Wyoming; Lakeview, oregon; Falls City and Ray Point, Texas). Wore recently, DuE has added a site in Caronsburg, Pennsylvania, and two sites in North Dakota (Belfield and Bowman), and deleted Ray point, Texas, for a total of 24 sites. llost of the mills at these sites produced by far the greatest part of their output of uranium under contracts with the ALC during the period 1947 through 1970 . After operations ceased, some companies made no attempt to stabilize the tailings, while otners did so with varying deyrees of success. Recently, concern has increased about the possible adverse effects to the general public from long-term exposure to low-level sources of radiation from the tailings piles and sites.

prior to 1975, the studies of radiation levels on and in the vicinities of these sites were linited in scope. The data available were insufficient to permit assessment of risk to people with any deyree of confidence. In addition, information on practicable measures to reduce radiation exposures and estinates of their projected costs was limited. The purposes of these recent studies performed by ${ }^{\prime B}$ \&DU have been to revise the information necessary to provide a basis for decision making for appropriate remedial actions for each of the 24 sites. 
Evaluations of the following factors have been included in this engineering assessment in order to assess the significance of the radiological conditions that exist today at the Belfield site:

(a) Exhalation of radon yas from the ash

(b) On-site and off-site direct radiation

(c) Land contamination from windblown ash

(d) Hydrology and contamination by water pathways

(e) Potential health impact

(f) Potential for extraction of additional minerals from the ash

Investigation of these and other factors has led to the evaluation of remedial action alternatives which are generally categorized as follows:

(a) Uption I - Stabilization of contaminated material on site with a $3-\mathrm{m}$ cover

(b) Option II - Disposal at site 3, uranium pit about $8 \mathrm{mi}$ from the belfield site

(c) Option III - Disposal at site 7, scoria pit about $4.8 \mathrm{mi}$ from the Belfield site

(d) Option IV - Disposal at site 8, uranium pit about $17 \mathrm{mi}$ from the Belfield site

$\underline{1.1 .1 \quad \text { Background }}$

On March 12, 1974, the Subcomrittee on Raw Materials of the Joint Committee on Atomic Energy (JCAE), Congress of the United States, held hearings on S. 2566 and H.R. 11378, identical bills submitted by Senator Frank E. Moss and Representative Wayne Owens of Utan. The bills provided for a cooperative arrangement between the AEC and the State of Utah in the area of the Vitro tailings site in salt Lake City.* The bills also provided for the assessment of an appropriate remedial action

*The proceedings of these hearings and the summary Report on the Phase I study were published by the JCAE as Appendix 3 to ERDA Authorizing Legislation for Fiscal Year 1976. Hearings before the subcommittee on Leyislation, JCAE, on Fusion Power, Biomedical and Environmental Researcn; Operational Safety; Waste Management and Transportation, Feb 18 and 27, 1975, Part 2. 
to linit the exposure of Individuals to sadiation from uranium mill tailings.

Dr. Williarn D. Rowe, testifying on behalf of the LPA, pointed out that there are other sites witi similar problems. He recommended that the problem be approached as a generic one, structured to address the most critical problen first.

Dr. James L. Liverman, testifying for the AEC, proposed that a comprehensive study should be rade of all such piles, rather than treating the potential problem on a piecemeal basis. He proposed that the study be a cooperative two-phase undertaking by the states concerned and the appropriate federal agencies, such as the AEC and EPA. Phase I would involve site visits to determine such aspects as their condition, ownership, proxinity to populated areas, prospects for increased population near the site, and need for corrective action. A preliminary report then would be prepared which would serve as a basis for determining if a detailed englneering assessment (Phase II) were necessary for each millsite. The Plase II study, if necessary, would incluue evaluation of tne probleins, examination of alternative solutions, preparation of cost estimates ana of detailed plans and specifications for alternative remedial action measures. This part of the study would include physical measurements to deternine exposure or potential exposure to the public.

The Phase I assessment began in May 1974, with teans consisting of representatives of the AEC, the EPA, and the states involved visiting 21 of the inactive sites. The Phase I report was presented to the JCAE in October 1974. Table 1-1, adapted from Reference 1 , summarizes the conditions in 1980. Based on the findings presented in the Phase I report, the decision was made to proceed with Phase II.

On May 5, 1975, ERDA, the successor to AE'C, announced that Ford, Bacon \& Davis Utah Inc. of Salt Lake City, Utah, had been selected to provide tne architect-engineering (A-E) services for Phase II. EIRA's Gralld Junction, colorado, Office (GJO) was autnorized to negotiate and administer the terms of a contract with FB\&DU. The contract was effective on June 23, 1975. The salt Lake city Vitro site was assignea as the initial task, and work began immediately.

On November 8, 1978, the Uranium Mill Tailings Radiation control Act of 1978 (PL 95-604) became effective. This leyislation provides for state participation with the Federal Government in tne remedial action for inactive tailings piles. Pursuant to requirements of PL 95-604, tne EPA has the responsibility to promulgate remedial action standards for the cleanup of areas contaminated with residual radioactive material and for disposal of tailings. The U.S. Nuclear Regulatory Commission ( $N R C$ ) has the responsivility for enforcing these standards. 
In 1979, DOE established the UMTRA Program office in Albuquerque, New Mexico. Work on the prograrn has since been directed by personnel in that office. The field work by FB\&DU in support of this report was performed during the week of June 16,1980 .

\subsubsection{Scope of Phase II Engineering Assessment}

Phase II A-E Services are divided into two stages: Title I and Title II.

Title I services include the engineering assessment of existing conditions and the identification, evaluation, and costing of alternative reluedial actions for each site. Following the selection and funding of a specific remedial action plan, 'ititle II services will be performed. These services will include the preparation of detailed plans and specifications for impleruentation of the selected remedial action.

The specific scope requirements of the Title I assessment may include but are not limited to tne following:

(a) Preparation of an engineering assessment report for each site, and preparation of a comprehensive report suitable for subinission to the Congress on reasonable remedial action alternatives and their estimated cost.

(b) Determination of property ownership in order to obtain release of Federal Government and A-E liability For performance of engineering assessment work at both inactive millsites and privately owned structures.

(c) Preparation of topographic maps of millsites and other sites to which tailings and other radioactive materials might be moved.

(d) Performance of core drillings and radiometric measurements ample to determine volumes of tailings and other radium-contaminated materials.

(e) Performance of radiometric surveys, as required, to determine areas and structures requiring cleanup or decontamination.

(f) Determination of the adequacy and the environmental suitability of sites at which mill tailings containing radium could be disposed; and once such sites are identified, perform evaluations and estimate the costs involved. 
(g) Performance of engineering assessments of structures where uranium laill tailings have been used in off-site construction to arrive at reconuendations and estimated costs of performing remedial action.

(h) Evaluation of variuus methods, techniques, and naterials for stabilizing uranium mill tailings to prevent wind and water erosion, to inhibit or elininate radon exhalation, and to minimize maintenance and control costs.

(i) Evaluation of availapility of suitable fill and stabilization cover materials that could be used.

(j) Evaluation of radiation exposures of individuals and nearby populations resulting from the inactive uranium millsite, with specific attention to:

(1) Gamina radiation

(2) Radon

(3) Radon daughter concentrations

(4) Radium and other naturally occurring radioisutopes in the tailings

(k) Review of existing information about site hydrology and neteorology.

(1) Evaluation of recoveriny residual values, such as uranium and vanadium in the tailings and other residues on the sites.

(a) Performance of demograpnic and land use studies. Investigation of corunumity and area planning, and industrial and yrowth projections.

(n) Evaluation of the alternative corrective actions for each site in orler to arrive at recommendations, estimated costs, and socioeconomic impact based on population and land use projections.

(o) Preparation of preliminary plans, specifications, and cost estimates for alternative corrective actions for each site.

site.

Not all of these itens received attention at the Belfield 


\subsubsection{Location and Topography}

The Belfield site is located in southwestern North Dakota about $19 \mathrm{mi}$ west of Dickinson, North Dakota, and 5 mi east of the Billings county-stark county border. The site is located on a nearly level piece of land immediately south of the North Branch of the Heart River. While elevations within a few hundred feet of the site vary from just less than 2,550 to 2,570 ft above sea level, the site is at about 2,565 ft above sea level. The Heart River, an intermittent stream, flows generally west to east in a channel 10 to $15 \mathrm{ft}$ below the general elevation of the site. The surrounding hills reach elevations of up to $2,700 \mathrm{ft}$. The original topography of the site may have been altered slightly by the addition of up to 2 to $3 \mathrm{ft}$ of scoria as roadbed material.

1.2.2 Ownership and History of Milling Operations and Processing

The present owner of the Belfield site is the Burlington Northern Railroad Company, which was formed by merger with Northern Pacific Railroad in 1970. The site has been owned by Burlington Northern or its predecessor since 1888 when the land was obtained as a land grant to Northern Pacific by the U.S. Government. The site was leased to Union Carbide Corporation, which constructed and operated the ashing plant from 1964 to 1966. In August 1968, Dakota Industries leased the site and purchased the structures to be used in the calcination of clay for use as cat litter. In December 1971, the L.P. Anderson Construction Company of Miles City, Montana, purchased the structures on the site and executed a lease for the use of a portion of the property.

The Union Carbide plant in Belfield started ashing operations in July 1964. Lignite, which contained as much as $0.358 \mathrm{U}_{3} \mathrm{O}_{8}$, was trucked to the site from several mines in the surrounding area. The wet lignite was burned in an 8-ft-dia by 125-ft-long rotary kiln rated at 100 tons/day capacity. Normal production rate was approximately 60 tons/day. The only process used involved the combustion of the organic material. No chemical, metallurgical, or nuclear processes were involved. The ash handling system was enclosed completely to control dust emissions. Dust was separated from the kiln off-gas stream by a cyclone and scrubber system and released to the atmosphere from a stack. The ash from the kiln was air-cooled in a rotary cooler and loaded into railroad cars which then were covered for shipment to Union Carbide's uranium ore processing plant in Rifle, Colorado.

Union Carbide suspended ashing operations at Belfield in october 1966. Before the plant was sold in 1968, the plant 
equiprnent, building, and yard were cleaned and decontaminated by Union Carbide, where necessary, to meet then-current AEC requirements.

\subsubsection{Present condition of the site}

Figure 2-3 is a descriptive map of the site as it now exists. The L.P. Anderson Construction Company has a maintenance shop and storaye area at the site, with its main building about 100 ft east of the concrete remains of the oriyinal kiln. The area east of the L.P. Anderson Building is used by the construction company for equipment storage. several old storage tanks, other equipment, and some new pipe are stored there, none of which appear to be contaminated. Also located on or adjacent to the site are a water well and the LP gas storage area of the Cenex Company, an agricultural cooperative.

The site has barbed-wire fencing on the north and east sides, but none on the south or west sides. rhere are no radiation warning signs posted at the site. Access is generally unrestricted.

\subsubsection{Contamination and Soil Characteristics}

No mill tailings pond or pile is present at the site because the ash from the kiln was collected and shipped to Rifle, Colorado, for further processing. However, radiation measurements showed that liost of the surrounding soil at the site is contaninated to depths of 6 to 12 in. The soil just east of the L.P. Anderson Building is contaninated to depths of 4 ft. The estinated anount of contaminated material, including material from cleanup of off-site areas, is 71,500 tons, as shown in Table 2-1.

\section{2 .5 Geology, Hydrology, and Meteorology}

The soils present on the site are classified as savage silty clay loams. The surface soil and the subsoil are generaliy from 2 to $3 \mathrm{ft}$ thick. Well logs in the area indicate that clays and silty clays are generally continuous to about a 6-ft deptn on these terraces.

The site is located on alluvial deposits of the Heart River which are largely silt and clay with a few beds of sand and gravel. The depth of the alluvial deposits in the site area is difficult to deternine since the underlying bedrock is poorly consolidated. It is definitely not more than $50 \mathrm{ft}$, where a lignite bed is located, and may be less than $20 \mathrm{ft}$. In many localities scoria beds are present. These are reddish masses of baked and fused clay, shale, and sandstone, which have been formed where seams of lignite have burned. 
The site is located on the south side of the north branch of the Heart River. In the vicinity of the site, the river is an intermittent stream since it drains only a small area. During summer months there may be areas of stagnant water in the streambed.

The Heart River in the vicinity of the site flows in a channel which is from 10 to 15 ft deep. The railroad bed south of the site protects the site from surface flows from the south. Therefore, surface flows arise only from rainfall directly on the site. Precipitation on the site drains either to the Heart River or to ponds on the site.

As shown in Figure 2-6, there are at least 16 wells within $1 \mathrm{mi}$ of the site, including four Belfield municipal supply wells in section 5, and at least 35 wells within $2 \mathrm{mi}$. At least four of these wells, all in section 4, are not in use. They appear to be test wells drilled by the city and are from 44 to 81 ft deep. One of these, shown in Figure 2-6, is the well directly north and downgradient of the site. The two wells just east and the one south of the site are the otner unused city wells. There are undoubtedly more wells than these in the area which are not registered with the state. Most of these are west of the site and not downgradient of the site. Therefore, water in the aquifers would not move from the site toward these wells, unless high pumping in the area should cause a cone of depression affecting the general hydrology of the site.

Wells to the north or downgradient of the site can be affected by water flowing under the site. Any wells downstream and along the Heart River can be recharged by water flowing past the site, since the Heart River is an influent stream in this area.

At Dickinson, the nearest weather reporting station, the mean annual precipitation is 15.9 in. Prevailing winds are from the west. Wind speeds measured at the Dickinson Municipal Airport are usually moderate, with 708 of the observations less than $16 \mathrm{mi} / \mathrm{hr}$, and about 958 less than $22 \mathrm{mi} / \mathrm{hr}$. Wind information for the area is presented in Table 2-2.

\subsection{RADIOACTIVITY AND POLLUTANT IMPACTS ON THE ENVIRONMENT}

The principal environmental radiological impact and associated health effects arise from the $230_{\mathrm{Th}}, 226_{\mathrm{Ra}}, 222 \mathrm{Rn}$, and $222 \mathrm{Rn}$ daughters contained in the residues. Although these radionuclides occur in nature, their concentrations in uranium ore and lignite ash are several orders of magnitude greater than their average concentrations in the earth's crust. 
1.3.1 Radiation Exposure Pathways, Contamination Mechanisms, and Background Levels

The major potential environmental routes of exposure to man are:

(a) Inhalation of $222 \mathrm{Rn}$ and its daughter products, resulting from the continuous radioactive decay of $226_{\mathrm{Ra}}$ in the ash. Radon is a gas that diffuses from the site. The principal exposure results from inhalation of $222 \mathrm{Rn}$ daughters. This exposure affects the lungs. For this assessment, no criteria nave been established for racion concentrations in air. However, the pathway for radon and radon daughters accounts for the major portion of the exposure to the population.

(b) External whole-body gamma exposure directly from radionuclides at the site.

(c) Inhalation and ingestion of windblown ash. The primary health effect relates to the alpha emitters $230 \mathrm{Th}$ and $226_{\mathrm{Ra}}$, each of winich causes exposure to the bones and lungs.

(d) Ingestion of ground and surface water contaminated with radioactive elements (primarily $226_{\mathrm{Ra}}$ ) and other toxic materials.

(e) Contamination of food through uptake and concentration of radioactive elements by plants and animals is another pathway that can occur; however, this pathway was not considered in this study.

\subsubsection{Radon Gas Diffusion and Transport}

Ho measurements of atmospheric radon concentrations in the Belfield area were made since calibrated instrumentation was not available at the time of the field work. The background radon concentration was estinated to be $1 \mathrm{pCi} / 1$.

Measurements of the radon exhalation flux from the tailings using the charcoal canister technique(3) ranged from less than 1 to about $63 \mathrm{pci} / \mathrm{m}^{2}-\mathrm{s}$ on and adjacent to tne ash site. The area-weighted average radon flux was estimated to be about $20 \mathrm{pCi} / \mathrm{m}^{2}-\mathrm{s}$. Radon flux depends principally on radium content of tailings or ash; however, it also varies considerably because of moisture, soil characteristics, and climatological conditions. 


\subsubsection{Direct Gamma Radiation}

The external gamma radiation (EGR) levels measured on and adjacent to the site are shown in Figure 3-4. These measurements were made with a scintillation detector. The highest uncorrected EGR rate $(800 \mu R / h r)$ was measured between grid points (about $650 \mathrm{ft}$ east of the L.P. Anderson Building) in the area where there is no scoria cover. The lowest uncorrected EGR level on site was about $35 \mu \mathrm{R} / \mathrm{hr}$. The uncorrected EGR levels along the boundary adjacent to the railroad were generally higher than in other areas of the site.

The background EGR levels in the vicinity of Belfield range between 8 and $15 \mu \mathrm{R} / \mathrm{hr}$, with an average of about $10 \mu \mathrm{R} / \mathrm{hr}$.

1.3.1.3 Windblown Contaminants

The estimated 5-pCi/g contour around the site is indicated in Figure 3-5. The maximum extent of windblown contamination is about $400 \mathrm{ft}$ north of the site boundary and about $100 \mathrm{ft}$ north of the Cenex boundary, while the minimum extent is about $200 \mathrm{ft}$ south of the site.

Measurements of $226_{\mathrm{Ra}}$ concentrations in three soil samples from the vicinity ranged from 1.5 to $2.5 \mathrm{pCi} / \mathrm{g}$, with an average of about $2.0 \mathrm{pCi} / \mathrm{g}$.

\subsubsection{Surface and Ground Water Contamination}

Three surface water samples and two samples from wells were taken in the site vicinity and analyzed. The locations of these samples are shown in Figure $3-6$.

These water samples showed the gross alpha content to be less than $2 \mathrm{pCi} / 1$, while the $226_{\mathrm{Ra}}$ content was less than $0.6 \mathrm{pCi} / 1$. The $238 \mathrm{u}$ concentration ranged from 0.03 to 0.08 $\mathrm{pCi} / 1$ for the surface water samples and less than $0.01 \mathrm{pCi} / 1$ for the ground water samples. Arsenic concentrations did not exceed $0.041 \mathrm{ppm}$. In all cases, the concentrations of those elements measured did not exceed Interim Primary Drinking Water Regulations. (4)

\section{3 .1 .5 Soil Contamination}

Contamination of soil below the existing grade at the site was determined both by gamma logging of drill holes and by radiometric analysis of soil samples taken from drill holes. In most cases, radium activity was greatest in the first 2 ft below existing grade, and in no case was activity above background levels detected at depths greater than $4 \mathrm{ft}$. 


\subsubsection{Remedial Action Criteria}

In the following paragraphs, where reference is made to tailings, the statement should be interpreted as being directly applicable to residual radioactive materials at the Belfield site.

Since enactment of the Uranium Mill Tailings Radiation Control Act of 1978 (PL 95-604), which was effective November 8, 1978, the EPA has published interim (45 FR 27366) and proposed (45 FR 27370) standards for structures and open lands. These standards establish the indoor radon daughter concentration, including background, below which no remedial action is indicated at $0.015 \mathrm{WL}$. The indoor gamma radiation limit is $0.02 \mathrm{mR} / \mathrm{hr}$ above background.

For open land, remedial action must provide reasonable assurance that the average concentration of $226_{\mathrm{Ra}}$ attributable to residual radioactive material from any designated processing site in any 5-cm thickness of soils or other materials within $1 \mathrm{ft}$ of the surface, or in any $15-\mathrm{cm}$ thickness below $1 \mathrm{ft}$, shall not exceed $5 \mathrm{pCi} / \mathrm{g}$.

Environmental standards have been proposed by the EPA (46 FR 2556) for the disposal of residual radioactive materials from inactive uranium processing sites. These standards require that disposal of residual radioactive materials be conducted in a way which provides a reasonable assurance that for at least 1,000 yr following disposal:

(a) The average annual release of $222 \mathrm{Rn}$ from the disposal site to the atmosphere by residual radioactive materials will not exceed $2 \mathrm{pci} / \mathrm{m}^{2}-\mathrm{s}$.

(b) Substances released from residual radioactive materials after disposal will not cause:

(1) the concentrations of those substances in any underground source of drinking water to exceed the level specified below, * or

(2) an increase in the concentrations of those substances in any underground source of drinking water where the concentrations of those substances prior to remedial action exceed the levels specified below for causes other than residual radioactive materials.*

\footnotetext{
*These requirements apply to the dissolved portion of any substance listed above at any distance greater than $1.0 \mathrm{~km}$ from a disposal site that is part of an inactive processing site, or greater than $0.1 \mathrm{~km}$ if the disposal site is a depository site.
} 


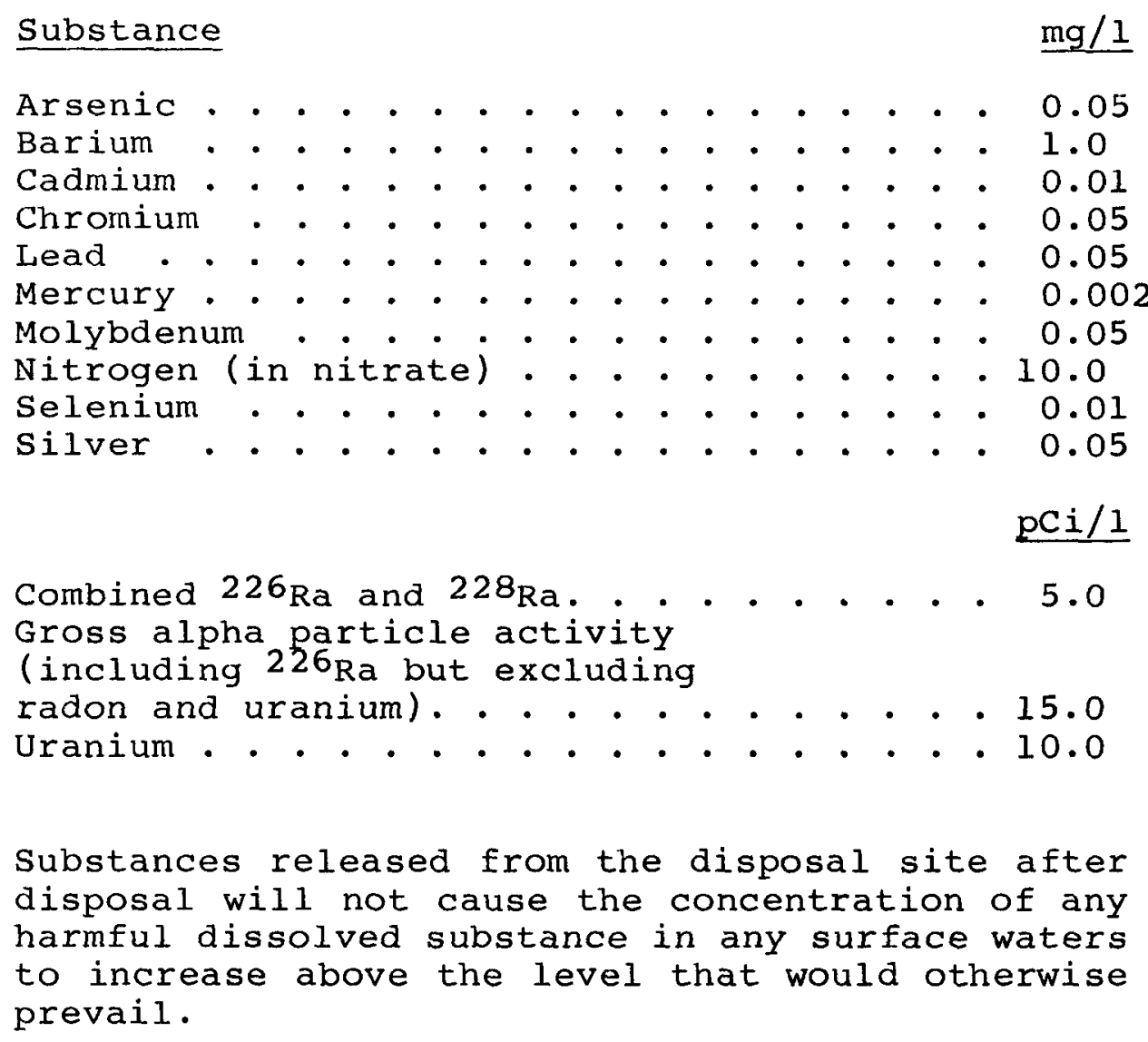

Since the passage of PL 95-604, the NRC has published final regulations for uranium mill tailings licensing in the Federal Register (45 FR 65521). They include the requirement that the stabilization method must include an earth cover of at least 3-m thickness and sufficient to reduce the radon emanation rate from the tailings to less than $2 \mathrm{pci} / \mathrm{m}^{2}-\mathrm{s}$ above background. In addition, seepage of materials into ground water should be reduced by design to the maximum extent reasonably achievable.

While these standards may undergo further revisions, the interim and proposed standards as indicated above form the basis for determining required remedial actions and their associated costs.

\subsubsection{Potential Health Impact}

Radon gas exhalation from the Belfield site and the subsequent inhalation of radon daughters account for most of the total dose to the population from the site under present conditions. The gamma radiation exposure from the site is very small since there are very few persons who live or work within $0.2 \mathrm{mi}$ of the site, where gamma radiation is above background. However, external gamma radiation exposure on the site is comparable to that at other inactive uranium millsites. 
Gamma radiation can be reduced effectively by shielding with any dense material. However, experience has shown that it is very difficult to control the movement of radon gas through porous materials. Once released from the radiumbearing minerals in the ash, the gaseous radon diffuses by the path of least resistance to the surface. The radon has a half-life of about 4 days, and its daughter products are solids. Therefore, part of the radon decays en route to the surface and leaves daughter products within the ash. If the diffusion path can be made long enough, then, theoretically, virtually all of the radon and its daughter products will have decayed before escaping to the atmosphere. Calculations using the theoretical techniques of Kraner, Schroeder, and Evans(5) earlier indicated that $13 \mathrm{ft}$ of earth cover would be required to reduce the radon diffusion from the contaminated material by 958 . Later experimental work(6) has demonstrated that 2 to $3 \mathrm{ft}$ of compacted clay may be sufficient to reduce radon flux to less than $2 \mathrm{pCi} / \mathrm{m}^{2}-\mathrm{s}$, assuming the continued integrity of the clay cover.

The health significance to man of long-term exposure to low-level radiation is a subject that has been studied extensively. Since the end results of long-term exposure to low-level radiation may be diseases such as lung cancer or leukemia, which are also attributable to many other causes, the determination of specific cause in any given case becomes very difficult. Therefore, the usual approach to evaluation of the health impact of low-level radiation exposures is to make projections from observed effects of high exposures on the premise that the effects are linear. A considerable amount of information has been accumulated on the high incidence of lung cancer in uranium miners and others exposed to radon and its daughters in mine air. This provides a basis for calculating the probable health effects of low-level exposure to large populations. (The term "health effect" refers to an incidence of disease; for radon daughter exposure, a health effect is a case of lung cancer.) This is the basis of the health effects calculated in this report. It should be recognized, however, that there is a large degree of uncertainty in such projections. Among the complicating factors is the combined effect of radon daughters with other carcinogens. As an example, the incidence of lung cancer among uranium miners who smoke is far higher than can be explained on the basis of either smoking or the radiation alone.

The risk estimators used in this report are given in the report of the National Academy of Sciences Advisory Committee on the Biological Effects of Ionizing Radiation (BEIR-III report). (7) This report presents risk estimators for lung cancer derived from epidemiological studies of both uranium miners and fluorspar miners. The average of the age-dependent absolute risk estimator for these two groups as applied to the population at large is 150 cancers per year 
per $10^{6}$ person-WLM of continuous exposure, assuming a lifetime plateau to age 75. The term WLM means working level months, or an exposure to a concentration of one working level of radon daughter products in air for $170 \mathrm{hr}$, which is a work-month. A working level (WL) is a unit of measure of radon daughter products which recognizes that the several daughter elements are frequently not in equilibrium with each other or with the parent radon. Because of the many factors that contribute to natural biological variability and of the many differences between exposure conditions in mines and residences, this estimator (150 cancer cases per year per $10^{6}$ person-WLM of continuous exposure) is considered to have an uncertainty factor of about 3. Another means of expressing risk is the relative risk estimator, which yields risk as a percentage increase in health effects per $10^{6}$ person-WLM of continuous exposure. However, this method has been shown to be invalid(8) and is not considered in this assessment.

For the purpose of this engineering assessment, it was assumed that about $50 \%$ equilibrium exists inside structures between radon and its daughter elements resulting in the following conversion factors:

$$
1 \mathrm{pCi} / 1 \text { of } 222 \mathrm{Rn}=0.005 \mathrm{WL}
$$

For continuous exposure:

$$
0.005 \mathrm{WL}=0.25 \mathrm{WLM} / \mathrm{Yr}
$$

On the basis of predictions of radon concentrations in excess of the background value, it was calculated that under present conditions the average lung cancer risk attributable to radon released from the ash residues in the vicinity within $2 \mathrm{mi}$ of the Belfield site is less than $1.6 \times 10^{-7}$ per person per year, or less than 0.18 of the average lung cancer risk due to all causes for North Dakota residents $\left(2.3 \times 10^{-4}\right) .(9)$

The 25-yr health effects were estimated on the basis of present site conditions for three population projections using the present population of 1,650 in the $0-$ to $2-\mathrm{mi}$ area, and are presented below. These calculations assume that no habitable structures will be built on the radioactive residues shown in Figure 3-5. 
25-Year Cumulative Health Effects Within 2 Miles of Edge of Site

Projected Population Growth

0.68 constant growth rate 2.38 declining growth rate* 48 declining growth rate*
Site-Induced RDC Background RDC

$\begin{array}{ll}0.006 & 1.6 \\ 0.008 & 1.8 \\ 0.008 & 2.1\end{array}$

The site-induced radon daughter health effects are less than $1 \%$ of the background radon daughter health effects for the $0-$ to 2-mi area, based on the estimated background radon concentration of $1 \mathrm{pCi} / 1$. This exposure and consequent risk will continue as long as the radiation source remains in its present location and condition.

1.3.4 Nonradioactive Pollutants

Soil and water samples taken in the vicinity of the Belfield site indicate unusually high concentrations of arsenic. The data are insufficient to implicate or dismiss the ashing site as the source of this contamination.

\subsection{SOCIOECONOMIC AND LAND USE IMPACTS}

The land in the area near the Belfield site is used primarily for agricultural purposes, although being located adjacent to a railroad, there is potential for commercial or light industrial applications.

The presence of the contaminants on site does not appear to have any significant influence on property values or land usage. The current market value of the Belfield site is estimated at the rate of $\$ 10,000 / a c r e$, whereas the adjacent agricultural land has an estimated market value of $\$ 150$ to $\$ 400 /$ acre.

\subsection{RECOVERY OF RESIDUAL VALUES}

There is no appreciable mineral value in the contamination at the Belfield site. Therefore, no consideration was given to the possibility of reprocessing residual ash.

\subsection{MILL TAILINGS STABILIZATION}

Although little ash remains at the Belfield site, contamination from the cleanup of off- and on-site areas must be disposed of properly. Since remedial action for this contaminated material must satisfy the same requirements as uranium mill tailings, the following discussion of stabilization methods for uranium mill tailings is presented.

\footnotetext{
*Declines linearly from its initial value to zero in 25 yr and remains constant at zero thereafter.
} 
Investigations of methods of stabilizing uranium mill tailings piles from wind and water erosion have indicated a variety of deficiencies among the methods. Chemical stabilization (treatment of the tailings surface) has been successful only for temporary applications and is thus viewed as inadequate for currently proposed disposal criteria. Volumetric chemical stabilization (solidifying the bulk of the tailings) techniques appear to be costly and of questionable permanence. Physical stabilization (emplacement of covers over the tailings) methods using soil, clay, or gravel have been demonstrated on a laboratory scale to be effective in stabilizing tailings. Artificial cover materials are attractive but have the disadvantage of being subject to degradation by natural and artificial forces. Vegetative stabilization (establishment of plant growth) methods are effective in limiting erosion. However, where annual precipitation is less than about 10 in., soil moisture content may be inadequate to ensure viability of the plant life.

Migration of contaminants into ground water systems must be limited under the NRC and EPA criteria. Control of water percolating through the tailings can be accomplished by stabilizing chemically, by physically compacting the cover material, and by contouring the drainage area and tailings cover surface. Isolation of the tailings from underlying ground water systems can be accomplished by lining a proposed disposal site with natural or artificial impermeable membranes.

Several materials have been identified which sufficiently retard radon migration so that the radon flux is substantially reduced, on a laboratory scale. Unfortunately, no large-scale application has been undertaken which would demonstrate that these materials satisfy all of the technical criteria in the EPA-proposed standards and the NRC regulations for licensing of uranium mills. However, extensive investigations of these questions continue in the Technology Development program of the Uranium Mill Tailings Remedial Actions project office in Albuquerque, New Mexico.

In view of findings from stabilization research, it appears that physical stabilization of tailings with $3 \mathrm{~m}$ of well-engineered cover material may be sufficient to appropriately stabilize tailings at their disposal site to meet NRC regulations.

\subsection{OFF-SITE REMEDIAL ACTION}

Since the ash from the process was the valued and only product from the Belfield ashing operation, it was assumed that there has been no intentional removal of contaminated material for use in off-site applications. The responsibility to search for such possible off-site locations was beyond the scope of this assessment. 
The extent of windblown contamination was assessed and is shown in Figure 3-5. About 21 acres of land adjacent to the Belfield site are estimated to require cleanup in order to meet current requirements.

\subsection{DISPOSAL SITE SELECTION}

In this report, three of the alternative remedial action options include moving the contaminated material at the Belfield site to a disposal site. The corresponding three potential disposal sites were selected after consultation with local agencies, concerned individuals, and industry personnel. Each site was evaluated to a limited extent on the bases of hydrology, meteorology, geology, ecology, economics, and proximity to population centers.

Since the responsibility for disposal site selection lies primarily with the Federal Government, with input from the State, the disposal sites evaluated in this work must be considered only as tentative.

The locations of sites listed in Table $1-2$ as Options II through IV are shown in Figure 8-1. In each of these options, surface material would be removed, as appropriate, from the disposal area and stockpiled. A retaining dike and diversion ditches would be constructed if necessary. The tailings would be emplaced, contoured, and covered with a 3-m depth of soil. The surface would be covered with $0.3 \mathrm{~m}$ of riprap or vegetation established for erosion control, and the entire site would be fenced.

\subsection{REMEDIAL ACTIONS AND COST-BENEFIT ANALYSES}

\subsubsection{Remedial Action Options}

The remedial action options examined include stabilization of the residual radioactive material at the Belfield site in its present location, and removal of all radioactive materials to an area where these materials could be isolated from the public.

The four remedial action options for which cost estimates were made include stabilization on the present site with $3 \mathrm{~m}$ of cover material and the removal of contaminated material to one of three possible locations. The options are summarized in Table 1-2.

The basis for comparison, from which the cost effectiveness of remedial alternatives can be judged, is the present condition of the site with no remedial action.

Option I represents remedial action activities to stabilize the ash more completely in its present location with the addition of $3 \mathrm{~m}$ of cover. Erosion would be controlled more 
completely and radon exhalation would be reduced to less than $2 \mathrm{pCi} / \mathrm{m}^{2}-\mathrm{s}$ above background. The site would have limited future use.

Options II through IV would require moving the contaminated material to specific disposal sites, as described in Chapter 8.

The relative total cost differences between these options are small and reflect variances in the haul distance, the haul route, and site preparation. The site that offers the most direct and easiest access is located 4.8 road miles east of the Belfield site. The scoria pits, only one of which is presently active, are located at this site. An inactive uranium pit located about $17 \mathrm{mi}$ southwest of the Belfield site is considered attractive because of its remoteness from significant development and the easy access for transportation during disposal activities.

\subsubsection{Cost-Benefit Analyses}

As summarized in Table 9-1, the total costs for the four remedial action options vary from about $\$ 1,500,000$ to about $\$ 2,500,000$. Each of these options would have associated health and monetary benefits. The options are identified by number in Paragraph 1.1 .

The number of cancer cases avoided per million dollars expended for each option is given in Figure 9-2. The curves in Figure 9-2 indicate an increase in benefit-cost ratio with time due to the greater reduction in population exposure over longer periods of time as a result of remedial action. The potential cancer cases avoided for each option and the cost per potential cancer case avoided are given in Table 9-2. 
TABLE $1-1$

SUMMARY OF CONDITIONS NOTED AT TIME OF 1980 SITE VISITS

\begin{tabular}{|c|c|c|c|c|c|c|c|c|c|c|}
\hline $\begin{array}{l}\text { Con } \\
\text { of } \\
\text { Tai }\end{array}$ & $\begin{array}{l}\text { dition } \\
\text { lingsa }\end{array}$ & $\begin{array}{l}\text { Condition } \\
\text { of } \\
\text { Structures } \\
\text { On site } \\
\end{array}$ & $\begin{array}{l}\text { Mill } \\
\text { Housinge }\end{array}$ & $\begin{array}{l}\text { Adequate } \\
\text { Fencing, } \\
\text { Posting, } \\
\text { Security } \\
\end{array}$ & $\begin{array}{l}\text { Property } \\
\text { Close to } \\
\text { River or } \\
\text { Stream } \\
\end{array}$ & $\begin{array}{l}\text { Houses or } \\
\text { Industry } \\
\text { within } \\
0.5 \mathrm{Mi} \\
\end{array}$ & $\begin{array}{l}\text { Evidence } \\
\text { of Wind } \\
\text { or Water } \\
\text { Erosion } \\
\end{array}$ & $\begin{array}{l}\text { Possible } \\
\text { Water } \\
\text { Contam- } \\
\text { ination } \\
\end{array}$ & $\begin{array}{l}\text { Tailings } \\
\text { Removed } \\
\text { for } \\
\text { Private } \\
\text { Use } \\
\end{array}$ & $\begin{array}{l}\text { Other } \\
\text { Hazards } \\
\text { On Site }\end{array}$ \\
\hline \multicolumn{11}{|l|}{ ARIZONA } \\
\hline$\overline{\text { Monument Valley }}$ & $\mathrm{U}$ & $\mathbf{R}$ & $\mathbf{N}$ & No & No & Yes & Yes & No & Yes & No \\
\hline Tuba City & $\mathrm{U}$ & $P R-U O$ & $E-P$ & No & No & Yes & Yes & No & No & Yes \\
\hline \multicolumn{11}{|l|}{ COLORADO } \\
\hline$\overline{\text { Durango }}$ & $\mathrm{P}$ & $\mathrm{PR}-\mathrm{UO}$ & $\mathbf{N}$ & Yes & Yes & Yes & Yes & No & Yes & Yes \\
\hline Grand Junction & $\mathbf{S}$ & $\mathrm{PR}-\mathrm{O}$ & $\mathbf{N}$ & Yes & Yes & Yes & Yes & Yes & Yes & No \\
\hline Gunnison & $\mathbf{S}$ & $B-O$ & $\mathbf{N}$ & No & Yes & Yes & No & Yes & No & No \\
\hline Maybell & $\mathbf{S}$ & $\mathbf{R}$ & $\mathbb{N}$ & Yes & No & No & Yes & No & No & No \\
\hline Naturita & RMS & $P R-O$ & $\mathbf{N}$ & Yes & Yes & Yes & Yes & Yes & No & No \\
\hline New Rifle & $\mathrm{P}$ & $M-O$ & $\mathbf{N}$ & Yes & Yes & Yes & Yes & Yes & No & No \\
\hline Old Rifle & $\mathbf{s}$ & PR-UO & $\mathrm{N}$ & Yes & Yes & Yes & No & Yes & Yes & No \\
\hline Slick Rock (NC) & $\mathbf{S}$ & $\mathbf{R}$ & $\mathrm{N}$ & Yes & Yes & Yes & Yes & Yes & No & No \\
\hline Slick Rock (UCC) & $\mathbf{S}$ & $\mathbf{R}$ & $\mathrm{E}-\mathrm{P}$ & Yes & Yes & Yes & No & Yes & No & No \\
\hline \multicolumn{11}{|l|}{ IDAHO } \\
\hline$\overline{\text { Lowman }}$ & $\mathrm{U}$ & $\mathbf{R}$ & $\mathbf{N}$ & No & Yes & Yes & Yes & Yes & Yes & No \\
\hline \multicolumn{11}{|l|}{ NEW MEXICO } \\
\hline Ambrosia Lake & U & $P R-O$ & $\mathbf{N}$ & No & No & No & Yes & No & No & No \\
\hline Shiprock & $\mathbf{S}$ & $\mathrm{PR}-\mathrm{O}$ & $\mathrm{N}$ & Yes & Yes & Yes & No & Yes & Yes & No \\
\hline \multicolumn{11}{|l|}{ NORTH DAKOTA } \\
\hline Belfield & $\mathbf{R}$ & $\mathrm{PR} \multimap \mathrm{O}$ & $\mathbf{N}$ & No & No & Yes & No & No & No & No \\
\hline Bowman & $\mathbf{R}$ & $\mathbf{R}$ & $\mathbf{N}$ & No & No & No & No & No & No & No \\
\hline \multicolumn{11}{|l|}{ OREGON } \\
\hline$\overline{\text { Lakeview }}$ & $\mathbf{S}$ & $B-O$ & $\mathbf{N}$ & Yes & No & Yes & Yes & No & No & No \\
\hline
\end{tabular}


TABLE 1-1 (Cont)

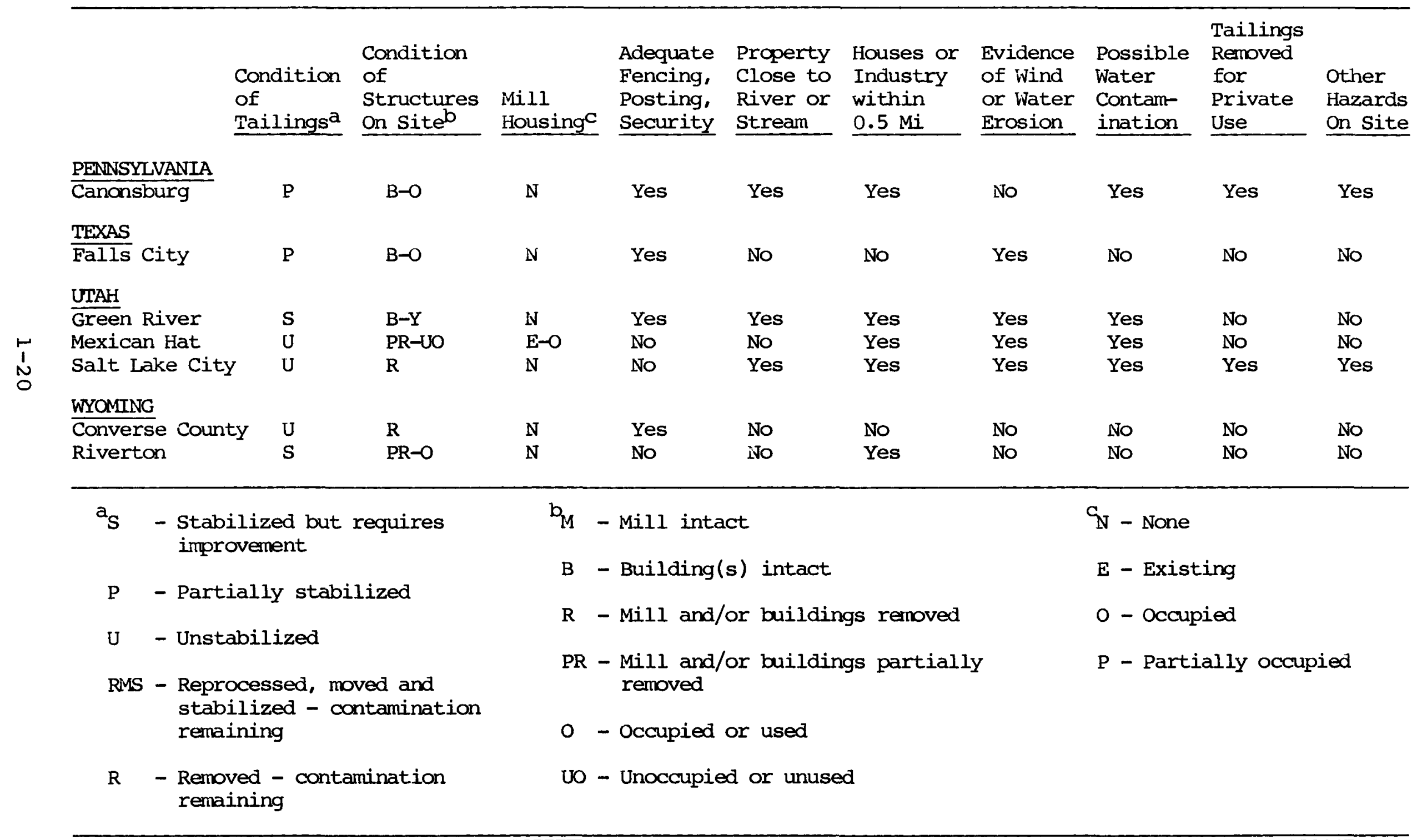


TABLE $1-2$

SUMMARY OF REMEDIAL ACTION OPTIONS AND EFFECTS

\begin{tabular}{|c|c|c|c|c|}
\hline $\begin{array}{l}\text { Option } \\
\text { Number }\end{array}$ & $\begin{array}{l}\text { Site } \\
\text { Specific } \\
\text { Cost } \\
(\$ 000) \\
\end{array}$ & Description of Remedial Action & Benefits & $\begin{array}{l}\text { Adverse } \\
\text { Effects }\end{array}$ \\
\hline I & 1,500 & $\begin{array}{l}\text { Existing structures not in use would be } \\
\text { demolished and the debris buried on site; } \\
\text { structures in use would be decontaminated } \\
\text { as necessary; the contaminated material } \\
\text { would be placed in a pit excavated on } \\
\text { site and stabilized with } 3 \text { m of local } \\
\text { earth cover. Natural vegetation would be } \\
\text { established or a riprap cover provided. } \\
\text { off-site contaminated soil would be } \\
\text { cleaned up. }\end{array}$ & $A, B, C, F$ & $X, Y, Z$ \\
\hline I I & 2,200 & $\begin{array}{l}\text { The ash, contaminated soil, and rubble } \\
\text { would be removed by truck to site } 3 \text {, } \\
\text { uranium pit located about } 8 \mathrm{mi} \text { north of } \\
\text { the Belfield site. The Belfield site } \\
\text { would be decontaminated as in Option I } \\
\text { and released for unlimited use. }\end{array}$ & $A-F$ & -- \\
\hline III & 2,200 & $\begin{array}{l}\text { Same as Option II, except contaminated } \\
\text { material removed to site } 7 \text {, scoria pit } \\
\text { located about } 4.8 \mathrm{mi} \text { east of the Belfield } \\
\text { site. }\end{array}$ & $A-F$ & -- \\
\hline IV & 2,500 & $\begin{array}{l}\text { Same as Option II, except contaminated } \\
\text { material removed to site } 8 \text {, uranium pit } \\
\text { located about } 7 \mathrm{mi} \text { south of the Belfield } \\
\text { site. }\end{array}$ & $A-F$ & -- \\
\hline
\end{tabular}


TABLE $1-2$ (Cont)

Notes

1. All options include on- and off-site remedial action.

2. For Options II through IV, costs include removal of up to 5 ft of contaminated earth at the ashing site.

Definition of Benefits

A. On-site windblown contamination cleaned up

B. Wind and water erosion controlled

C. Portions of the site not used for tailings available for other uses

D. The source of gamma radiation and radon gas removed from site

E. Total Belfield site available for unrestricted usage

F. Radon exhalation flux reduced to less than $2 \mathrm{pCi} / \mathrm{m}^{2}-\mathrm{s}$

\section{Definition of Adverse Effects}

$X$. Some security and maintenance required

Y. Tailings remain in the center of a growing area

Z. Restricted use of Belfield site 
1. "Summary Report, Phase I Study of Inactive Mill Sites and Tailings Piles"; AEC, Grand Junction, Colorado; Oct 1974.

2. S.D. Shearer, Jr., and C.W. Sill; "Evaluation of Radon-222 Near Uraniur Tailings Piles"; Department of Health, Education and Welfare, DER 69-1; Mar 1969.

3. R.J. Countess; "222Rn Flux Measurement with a Charcoal Canister"; Health Physics; Vol 31, p. 455; 1976.

4. Federal Register, Part II; EPA Interim Primary Drinking Water Regulations; EPA; July 9, 1976.

5. H.W. Kraner, G.L. Schroeder, and R.D. Evans; "Measurements of the Effects of Atmospheric Variables on Radon-222 Flux and Soil-Gas Concentrations"; The Natural Radiation Environment; J.A.S. Adams and W.M. Lowder, eds; University of Chicago Press; 1964 .

6. Argonne National Laboratory and Ford, Bacon \& Davis Utah, Inc.; "Characterization of Uranium Tailings Cover Materials for Radon Flux Reduction"; NUREG/CR-1081 (FBDU-218-1); Mar 1980.

7. "The Effects on Populations of Exposure to Low Levels of Ionizing Radiation": Report of Advisory Committee on Biological Effects of Ionizing Radiation; NAS, National Research Council; 1980.

8. B.L. Cohen; "The BEIR Report Relative Risk and Absolute Risk Models for Estimating Effects of Low Level Radiation"; Health Physics; Vol 37, p. 509; 1979.

9. Vital Statistics of the U.S.; Vol II; Mortality; National Center for Health Statistics; HEW; 1968. 
• 
$\sin$

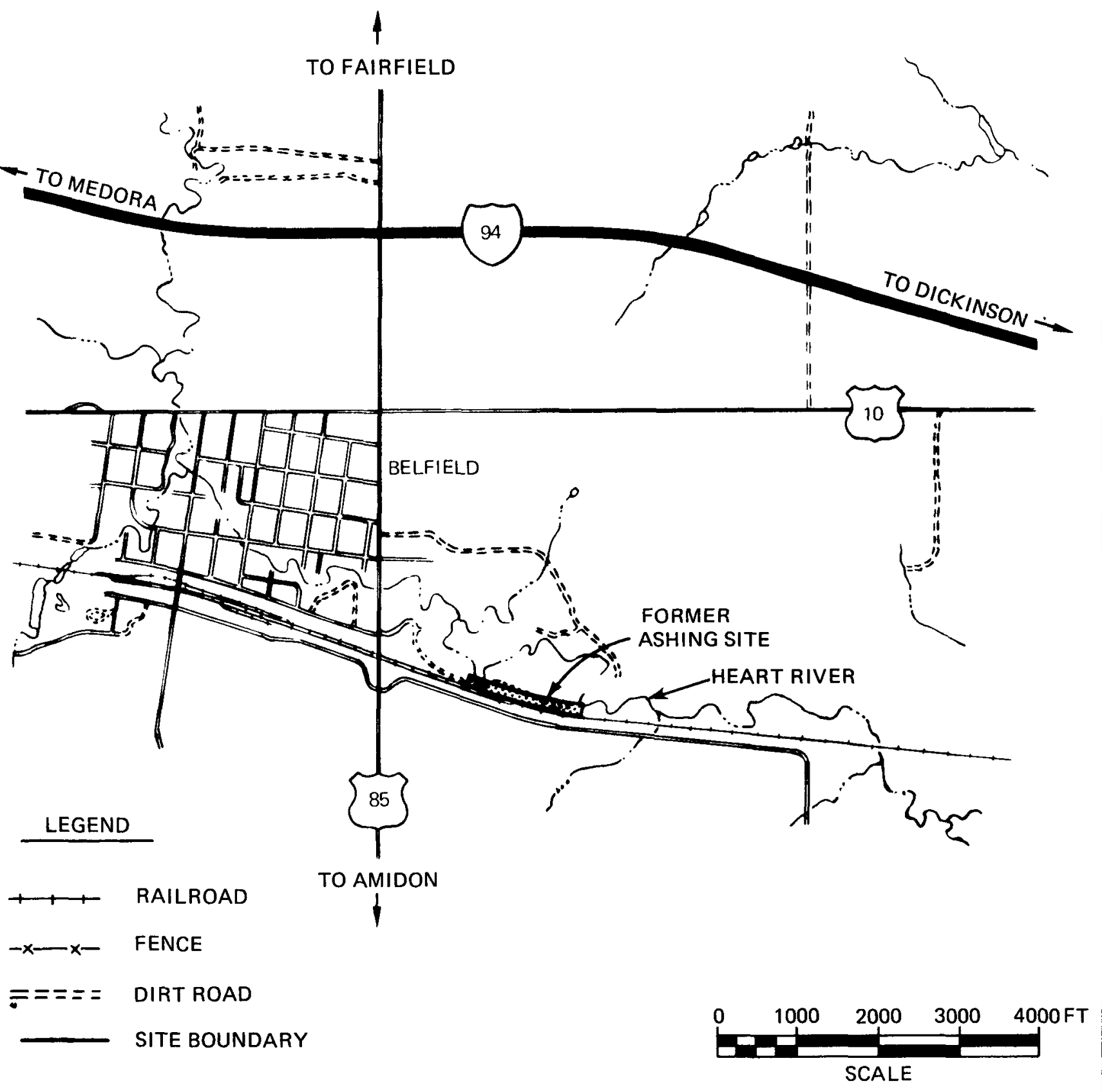


4

LEGEND

$\begin{array}{ll}\text { EDGE OF FORMER ASHING SITE } \\ -x- & \text { FENCE } \\ ==== & \text { DIRT ROAD } \\ \phi & \text { FB\&DU DRILL HOLE AND }\end{array}$

$\phi \quad \begin{aligned} & \text { FB\&DUDRILL HOLE AND } \\ & \text { SAMPLE LOCATIONS }\end{aligned}$

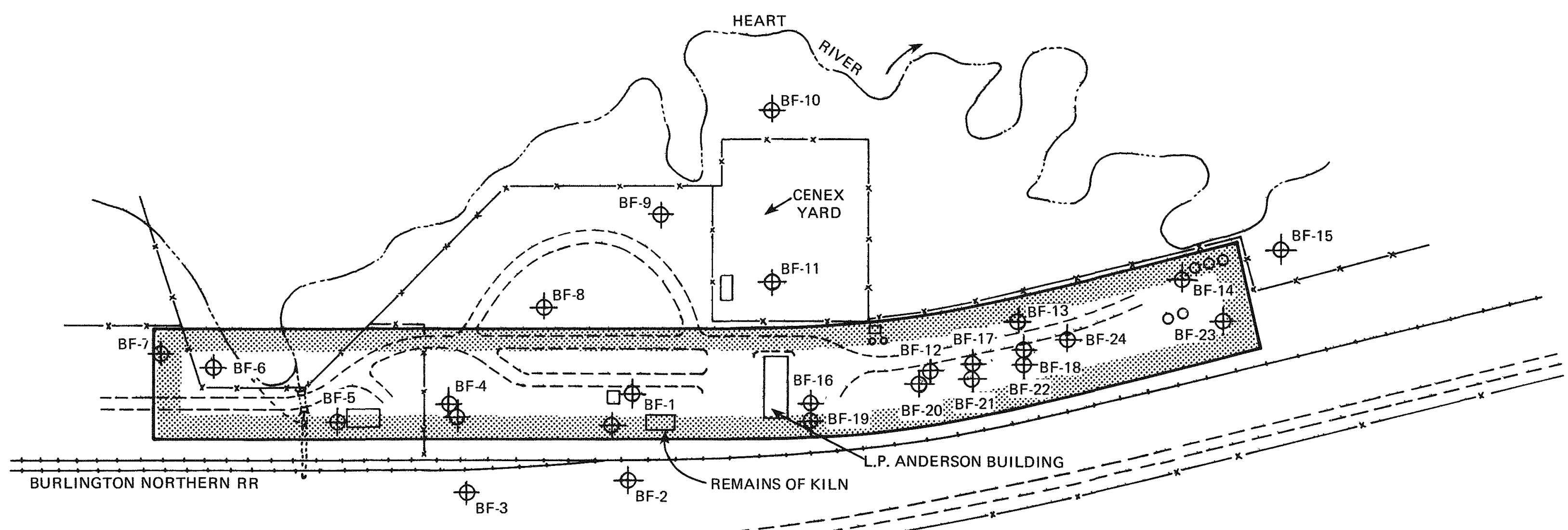

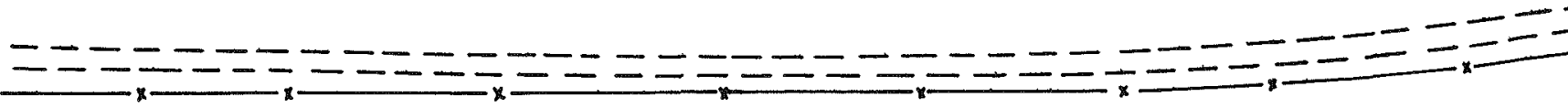

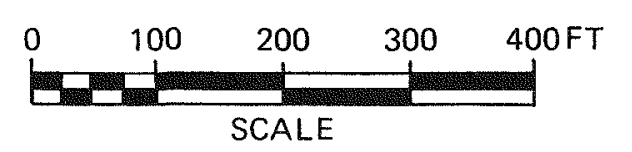


ffor , Isacon a Davie latab anc.

\begin{tabular}{|c|c|c|c|c|}
\hline ERA & PERIOD & GROUP & FORMATION & POSITION OF ASH \\
\hline \multirow[b]{2}{*}{ CENOZOIC } & QUATERNARY & $\begin{array}{l}\text { ALLUVIAL } \\
\text { DEPOSITES }\end{array}$ & & \multirow[t]{20}{*}{ BELFIELD SITE } \\
\hline & TERIARY & FORT UNION & $\begin{array}{l}\text { SENTINEL BUTTE } \\
\text { TONGUE RIVER } \\
\text { CANNONBALL AND LUDLOW }\end{array}$ & \\
\hline \multirow{5}{*}{ MESOZOIC } & \multirow{3}{*}{ CRETACEOUS } & MONTANA & $\begin{array}{l}\text { HELL CREEK } \\
\text { FOX HILLS } \\
\text { PIERRE }\end{array}$ & \\
\hline & & COLORADO & $\begin{array}{l}\text { NIOBRARA } \\
\text { CARLILE } \\
\text { GREENHORN } \\
\text { BELLE FOURCHE }\end{array}$ & \\
\hline & & DAKOTA & $\begin{array}{l}\text { MOWRY } \\
\text { NEWCASTLE } \\
\text { SKULL CREEK } \\
\text { FALL RIVER } \\
\text { DAKOTA }\end{array}$ & \\
\hline & JURASSIC & & $\begin{array}{l}\text { MORRISON } \\
\text { SWIFT } \\
\text { RIERDON } \\
\text { PIPER } \\
\end{array}$ & \\
\hline & TRIASSIC & & SPEARFISH & \\
\hline \multirow{13}{*}{ PALEOZOIC } & PERMIAN & & $\begin{array}{l}\text { MINNEKAHTA } \\
\text { OPECHE }\end{array}$ & \\
\hline & PENNSYLVANIAN & & MINNELUSA & \\
\hline & \multirow{3}{*}{ MISSISSIPPIAN } & & AMSDEN & \\
\hline & & BIG SNOWY & $\begin{array}{l}\text { HEATH } \\
\text { OTTER } \\
\text { KIBBEY }\end{array}$ & \\
\hline & & MADISON & $\begin{array}{l}\text { CHARLES } \\
\text { MISSION CANYON } \\
\text { LODGEPOLE } \\
\text { BAKKEN } \\
\end{array}$ & \\
\hline & \multirow{5}{*}{ DEVONIAN } & & THREE FORKS & \\
\hline & & SASKATCHEWAN & $\begin{array}{l}\text { NISKU } \\
\text { DUPEROW }\end{array}$ & \\
\hline & & BEAVERHILL LAKE & $\begin{array}{l}\text { SOURIS RIVER } \\
\text { DAWSON BAY }\end{array}$ & \\
\hline & & & $\begin{array}{l}\text { PRAIRIE } \\
\text { WINNIPEGOSIS }\end{array}$ & \\
\hline & & & ASHERN & \\
\hline & SILURIAN & INTERLAKE & INTERLAKE & \\
\hline & ORDOVICIAN & & $\begin{array}{l}\text { STONY MOUNTAIN } \\
\text { RED RIVER } \\
\text { WINNIPEG }\end{array}$ & \\
\hline & CAMBRIAN & & DEADWOOD & \\
\hline
\end{tabular}

\section{FIGURE 2-4. STRATIGRAPHIC COLUMN}




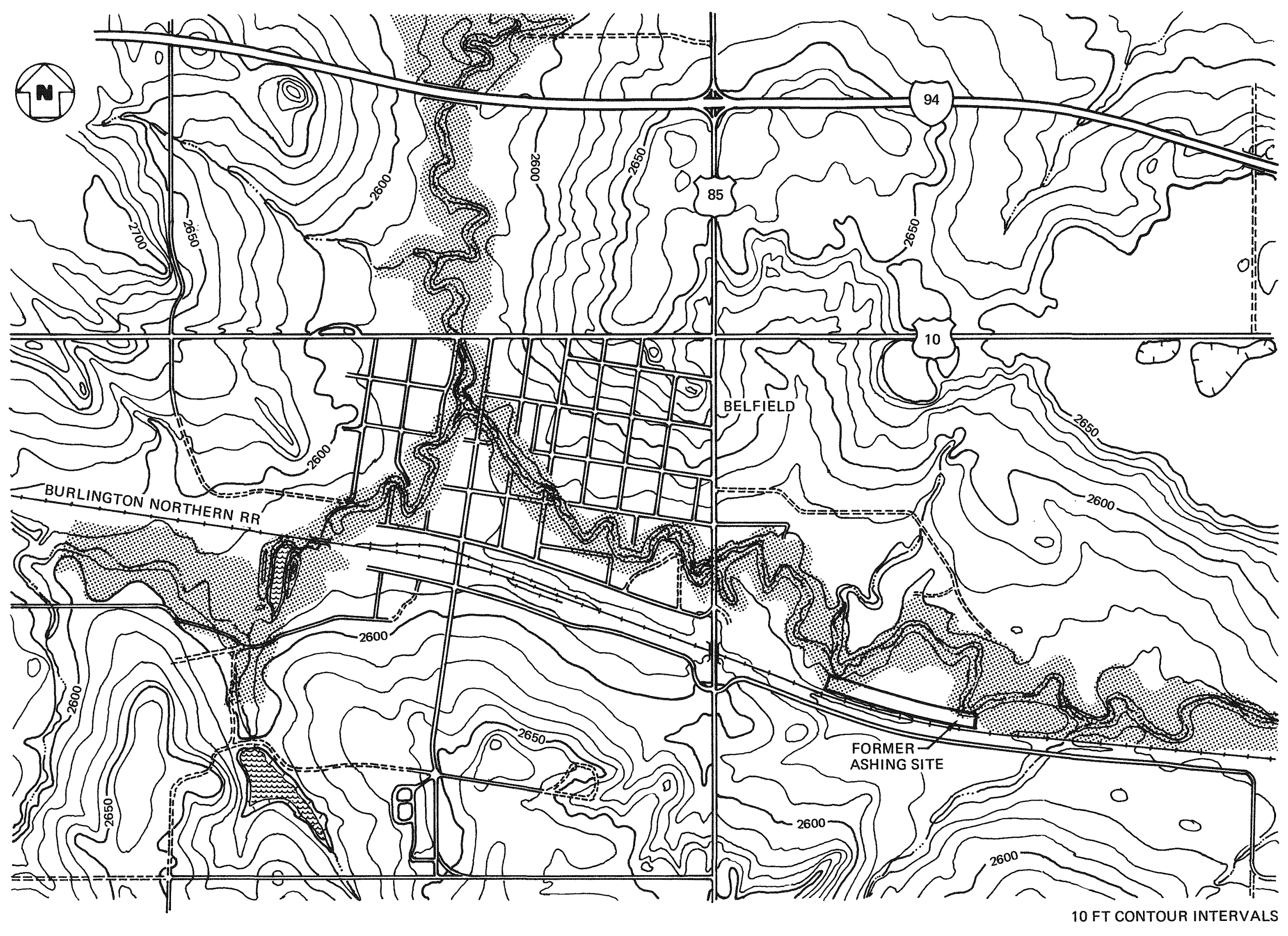

LEGEND

FI FLOD PRONE AREAS

RESERVOIR

$====$ DIRT ROAD

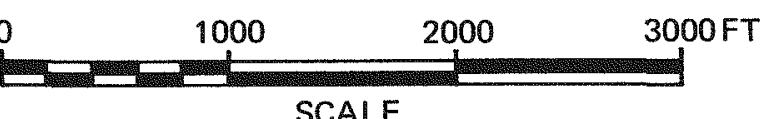




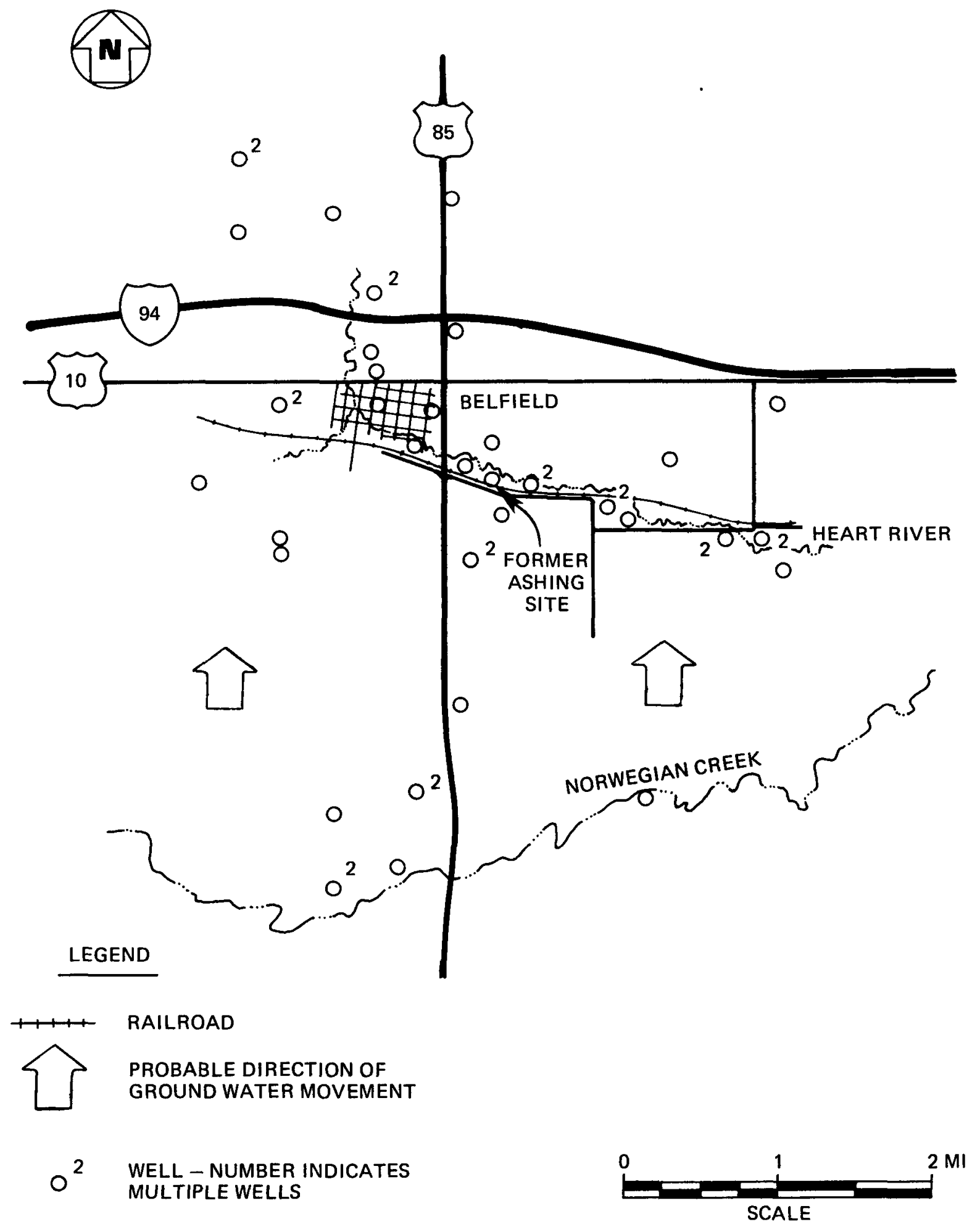

FIGURE 2-6. LOCATION OF WELLS NEAR BELFIELD 
Material

Contaminated Soil, Gravel, Rubble, and Scoria within site Boundaries ${ }^{a}$ Windblown Contaminated soil ${ }^{b}$

Totals

Volume
$\left(\mathrm{yd}^{3}\right)$

Weight

(tons)
39,600

17,000

56,600
50,000

21,500

71,500

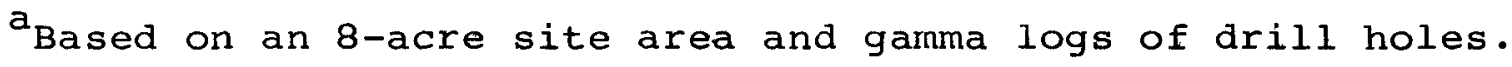

$\mathrm{b}_{\text {Based on }} 21$ acres contaminated to an average depth of 6 in. 
TABLE 2-2

FREQUENCY OF WIND DIRECTION AND SPEED

DICKINSON, N.D. MUNICIPAL AIRPORT (PERIOD: 1955-1967)(17)

\begin{tabular}{|c|c|c|c|c|c|c|}
\hline \multirow[b]{2}{*}{ Direction } & \multicolumn{3}{|c|}{ Wind Speed } & \multicolumn{3}{|c|}{ Range $(\mathrm{mi} / \mathrm{hr})$} \\
\hline & (calm) & $6-10$ & $\underline{11-16}$ & $\underline{17-22}$ & 23 & Total \\
\hline $\mathbf{N}$ & -- & 1.37 & 1.19 & 0.53 & 0.06 & 3.15 \\
\hline NNE & -- & 0.96 & 0.98 & 0.52 & 0.06 & 2.52 \\
\hline $\mathrm{NE}$ & -- & 1.17 & 1.02 & 0.55 & 0.06 & 2.80 \\
\hline ENE & -- & 1.55 & 0.97 & 0.45 & 0.05 & 3.02 \\
\hline $\mathrm{E}$ & -- & 1.48 & 1.26 & 0.53 & 0.05 & 3.32 \\
\hline ESE & -- & 1.70 & 1.95 & 1.15 & 0.16 & 4.96 \\
\hline $\mathrm{SE}$ & -- & 1.61 & 2.57 & 2.01 & 0.42 & 6.61 \\
\hline SSE & -- & 1.98 & 3.05 & 2.42 & 0.54 & 7.99 \\
\hline $\mathrm{s}$ & -- & 3.40 & 3.19 & 1.42 & 0.17 & 8.18 \\
\hline SSW & -- & 1.59 & 1.36 & 0.52 & 0.04 & 3.51 \\
\hline SW & -- & 1.49 & 1.15 & 0.49 & 0.05 & 3.18 \\
\hline WSW & -- & 2.57 & 2.61 & 1.21 & 0.14 & 6.53 \\
\hline $\mathrm{W}$ & -- & 3.54 & 4.35 & 2.42 & 0.47 & 10.78 \\
\hline WNW & -- & 2.78 & 4.60 & 4.63 & 1.66 & 13.67 \\
\hline $\mathbb{N W W}$ & -- & 1.52 & 2.42 & 3.05 & 1.25 & $8 \cdot 24$ \\
\hline NNW & -- & 1.31 & 1.70 & 1.33 & 0.27 & 4.61 \\
\hline Calm & 6.92 & -- & -- & -- & -- & 6.92 \\
\hline Total & 6.92 & 30.02 & 34.37 & 23.23 & 5.45 & 99.99 \\
\hline
\end{tabular}

Average wind speed - $13 \mathrm{mi} / \mathrm{hr}$ 
1. J.P. Bluemle; "The Face of North Dakota, The Geologic Story"; North Dakota Geological Survey, Educational Series $11 ; 1977$.

2. "Belfield Quadrangle, North Dakota"; 7.5 Minute Series Topographic Maps; United States Geological Survey; 1962 .

3. "Belfield S.W., North Dakota"; 7.5 Minute Series Topographic Maps; United States Geological Survey; 1962 .

4. W.N. Johnson, Union Carbide Corporation Representative; Letter to Robert Lowenstein, Director of the Division of Licensing and Regulation, AEC; subject: "Application for Source Material License, Union Carbide Corporation, Nuclear Division, Belfield, North Dakota"; Mar 20, 1964.

5. R.G. Beverly, Director of Radiation and Pollution Control, Mining and Metals Division of Union Carbide Corporation; letter to Donald A. Nussbaumer, Chief Source and special Nuclear Material Branch of the Division of Licensing and Regulation, AEC; subject: "Source Material License No. SUA-673 DML:DFH 40-7153"; DeC 10, 1968 .

6. Henry Trapp, Jr., and M.G. Croft; "Geology and Groundwater Resources of Hettinger and Stark Counties, North Dakota"; County Groundwater studies 16 - Part I; prepared by USGS in cooperation with North Dakota state Water Commission and Hettinger and Stark Counties Water Management Districts, 1975 .

7. North Dakota State Water Commission; Water Use Permits and Well Records for North Dakota; June 1980.

8. North Dakota Geological Survey; Bulletin 63; "Mineral and Water Resources of North Dakota"; 1973.

9. North Dakota Geological Survey Miscellaneous Series No. 57; "Oil Exploration and Development in the North Dakota Williston Basin"; 1979.

10. M. Hansen; "Structure iMap on Pre-Cambrian"; North Dakota Geological Survey; 1957.

11. C.A. Von Hake; "Earthquake History of North Dakota"; Earthquake Information Bulletin; U.S. Geological Survey; Vol 7, No. 6; Nov-Dec 1975. 
12. Flood Hazard Boundary Map, Stark County, North Dakota; Maps 16 and 17; Department of Housing and Urban Development; Federal Insurance Administration, 1976.

13. Overall Economic Development Program; prepared by the Roosevelt-Custer Regional Council; 1978.

14. "Surface Water Supply of the United States, 1966-1970, Part 6, Missouri River Basin"; Vol 2; USGS water Supply Paper 2117; 1973 .

15. North Dakota State Health Department; personal communication; July 1980 .

16. Belfield City Auditor; personal communication; July 1980.

17. "Dickinson, North Dakota (Airport) Percentage Frequency of Wind Direction and Speed, Period: 1955-1967"; Computation and Tabulation Sheet; U.S. Department of Commerce; NOAA National Weather Service.

18. "State of North Dakota, Tornado Breakdown by Counties, 1950-1979"; computer compiled data; U.S. Department of Commerce, NOAA National Weather Service; May 26, 1980.

19. "Tornadoes by Month and Year for North Dakota Since 1964"; computer compiled data; U.S. Department of Commerce, NOAA National Weather Service; 1979. 
CHAP'TER 3

RADIOACTIVITY AND POLLUTANT IMPACT ON THE ENVIROHMENT 
The principal objective of the assessment in this chapter is to determine the magnitude and characteristics of the radiation enitted from the Belfield lignite ashing site and the resulting potential exposure to the population residing and working in the vicinity of Belfield, North Dakota. In addition, this chapter briefly describes the potential radioactive and chemical pollutants and their pathways in the environment. The notations and abbreviations used are given in Table 3-1.

\subsection{RADIOACTIVE MATERIAL CHARACTERISTICS}

Hany elements spontaneously emit subatomic particles; therefore, these elements are radioactive. For example, when the most abundant uranium isotope, $238 \mathrm{U}$, undergoes radioactive decay, it emits a subatomic particle called an alpha particle; the $238_{\mathrm{U}}$ after undergoing decay becomes $234 \mathrm{Th}$, which is also radioactive; and $234 \mathrm{Th}$ subsequently enits a beta particle and becomes $234 \mathrm{~Pa}$. As snown in Figure 3-1, this process continues with either alpha or beta particles being emitted, and the affected nucleus thereby evolves from one element into another. It is noted in Figure 3-1 that $230 \mathrm{Th}$ decays to $226_{\mathrm{Ra}}$, which then decays to $222 \mathrm{kn}$, an isotope of radon. Radon, a noble gas, does not react chenically. The final product in the chain is $206 \mathrm{pb}$, a stable isotope that gradually accumulates in ores containing uranium. Uranium ore contains $226_{\mathrm{Ra}}$ and the other daughter products of the uranium decay chain. One of the daughters of $226 \mathrm{Ra}$ is the isotope $214_{\mathrm{Bi}}$, which emits a significant amount of electromagnetic radiation known as gamma radiation. Ganma rays are very similar to $x$-rays, only more penetrating. The $214 \mathrm{Bi}$ is the principal contributor to the gamma radiation exposure in the uranium-radium decay chain.

Besides knowing the radioactive elements in the decay chain, it is also important to know the rate at which they decay. This decay rate, or activity, is expressed in curies (Ci) or picocuries (pCi), where 1 pci equals $10^{-12} \mathrm{Ci}$ or $3.7 \times 10^{-2}$ disintegrations per second. The picocurie often is used as a unit of measure of the quantity of a radioactive element present in soil, air, and water.

Anotiner important parameter used in characterizing radioactive decay is known as the "half life", $\mathrm{T}_{1 / 2}$. This is the time that it takes for half of any initial quantity of the radioactive atorns to decay to a different isotope. For example, it takes $4.5 \times 10^{9}$ yr For half the $238 \mathrm{U}$ atoms to decay to $234 \mathrm{Th}$. Similarly, half of a given number of $222_{\mathrm{Rn}}$ atoms will decay in 3.8 days. 
The activity and the total number of radioactive atoms of a particular type depend on their creation rates as well as their half life for decay. If left undisturbed, the radioactive components of the decay chain shown in Figure 3-1 all reach the same level of activity, matching that of the longest-lived initiating isotope. This condition is known as secular equilibrium.

\subsection{RADIATION EFFECTS}

The radioactive exposure due to uranium residues from operations such as were carried out at the lignite ashing plant at Belfield, North Dakota, occurs from the absorption within the body of the eraitted alpha and beta particles, and gamila radiation. The range of alpha particles is very short; they affect an individual mainly when the alpha emitter is taken internally. Beta particles have a much lighter mass than alphas, and nave a longer range; but they still cause damage mainly to the sikin or internal tissues when taken internally. Gamina rays, however, are more penetrating than X-rays and can interact with all of the tissue of an individual near a gamma-enitting material.

The biological effects of radiation are related to the energy of the radiation; therefore, exposure to radiation is measured in terms of the energy deposited per unit mass of a given material. In the case of radon and its daughter products, the principal effect is from alpha particles emitted after the radon daughter products are inhaled.

The basic units of measurement for the alpha particles from short-lived radon daughters are the working level (WL) and the working level month (WLM). The working level is defined as any combination of the short-lived radon daughters in a liter of air that will result in the ultimate emission of $1.3 \mathrm{x} 10^{5} \mathrm{MeV}$ of alpha energy. The working level is so defined because it is a single unit of measure, taking into account the relative concentrations of radon daughter products which vary according to factors such as ventilation. One WLM results from exposure to air containing a radon daughter concentration (RDC) of 1 WL for a duration of $170 \mathrm{hr}$.

The basic units of measurement for gamma radiation exposure and absorption are the roentgen ( $R$ ) and the rad. one $\mathrm{R}$ is equal to an energy deposition of $88 \mathrm{ergs} / \mathrm{g}$ of dry air, and 1 rad is the absorbed dose that corresponds to the absorption of 100 ergs/g of material. The numerical difference between the magnitude of the two units is often less than the uncertainty of the measurements, so that exposure of $1 \mathrm{R}$ is often assumed to produce an absorbed dose of 1 rad or a dose equivalent of 1 rem. The rem is a measure of biological effect of the radiation on human tissue. (Refer to Glossary at the end of the report.) 
There are several sources of radiation that occur naturally in the environment. Natural soils contain trace amounts of uranium, thorium, and radium that give rise to radon gas and to alpha, beta, and yamma radiation. Three background soil samples were taken in the vicinity of Belfield. The average activity for each member of the uranium decay chain, assuming equilibrium, was $2 \mathrm{pCi} / \mathrm{g}$. The sample locations were within a 1-ni radius of the Belfield site; the corresponding $226_{R a}$ concentrations are shown in Figure 3-2. No previous measurements are known to be available for the area. Background values of the uranium chain vary with locations by a factor of 1.3 .

Another natural source of radiation in the environment results from the decay of $232 \mathrm{~T} n$, the predominant thorium isotope. The half-life of $232 \mathrm{Th}$ is $1.4 \mathrm{x} 10^{10} \mathrm{yr}$. It is also the parent of a decay chain containing isotopes of radium and radon. The average background value in the same off-site soil samples for each member of the thorium decay chain, assuming equilibrium, was less than $1 \mathrm{pCi} / \mathrm{g}$.

Measurements of background radon concentrations were not made since calibrated Wrenn chambers(1) were not available at the time of the field survey. However, an average background value of $1 \mathrm{pCi} / 1$ was assumed for the Belfield area.

Background external galuna radiation (EGR), measured $3 \mathrm{ft}$ above the ground, also was determined at several locations within $0.5 \mathrm{mi}$ of the site by using a calibrated scintillation detector. A value of $10 \mu R / h r$ was established as the average background rate, but the values ranged from 8 to $15 \mathrm{\mu R} / \mathrm{hr}$.

\subsection{RADIATION EXPOSURE PATHWAYS AND CONTAMINATION MECHANISMS}

As noted previously, the principal environmental radiological implications and associated health effects of uraniumcontaining lignite ash residues are related to radionuclides of the $238_{\mathrm{U}}$ decay chain: primarily $230_{\mathrm{Th}}, 226_{\mathrm{Ra}}, 222_{\mathrm{Rn}}$, and $222_{\mathrm{Rn}}$ daughters. Although these radionuclides occur in nature, their concentrations in ash raterials may be several orders of magnitude greater than in average natural soils and rocks. The major potential routes of exposure to man are:

(a) Inhalation of the $222 \mathrm{Rn}$ daughters, from decay of $222_{\mathrm{Rn}}$ escaping from the ashing site; the principal exposure hazard is to the lungs.

(b) External whole-body gamma exposure directly from tine radionuclides in the ash residues (primarily from $214 \mathrm{Bi}$ ) and in surface contamination frorn ashes spread in the general vicinity of the site. 
(c) Inhalation of windblown ash; the primary hazard relates to the alpha emitters $230_{\mathrm{Th}}$ and $226_{\mathrm{Ra}}$, each of which causes exposure to the bones and the lungs.

(d) Ingestion by man of ground or surface water contaminated from either radioactivity (primarily from $\left.226_{\mathrm{Ra}}\right)$ leached from the ash residues or from solids physically transported into surface water.

(e) Erosion and removal of ash material from the site by flood waters or heavy rainfall; this can create additional contaminated locations with the same problems as the original ashing site.

(f) Physical removal of the contaminated ash from the ashing site also provides a mechanism for contamination of other locations.

(g) Contamination of food through uptake and concentration of radioactive elements by plants and animals is another pathway that can occur; however, this pathway was not considered in this assessment.

The extent of radiation and pollution transport from the site into the environnent is discussed in the following paragraphs.

\subsubsection{Radon Gas Diffusion and Transport}

Radon flux measurements were made on the Belfield site using the charcoal canister tecnnique.(2) The canisters were placed at several locations on site, then removed after a suitable exposure period. After equilibrium had been achieved between radon and its daughters, the canisters were counted using a multichannel analyzer and the fluxes were calculated. Locations of the canisters and the measured radon fluxes are shown in Figure 3-3. The maximum flux observed on the site was $63 \mathrm{pCi} / \mathrm{m}^{2}-\mathrm{s}$, in an area about $650 \mathrm{ft}$ east of the $\mathrm{kiln}$ area, and the minimum flux measured on the site was $1.3 \mathrm{pCi} / \mathrm{m}^{2}-\mathrm{s}$, at the west end of the site. The area-weiyhted average flux was calculated to be about $20 \mathrm{pCi} / \mathrm{m}^{2}-\mathrm{s}$.

In October 1979, measured flux values were $46 \mathrm{pci} / \mathrm{m}^{2}-\mathrm{s}$, about $700 \mathrm{ft}$ east of the kiln area, and $5 \mathrm{pCi} / \mathrm{m}^{2}-\mathrm{s}$ near the Cenex LP gas storage facility. (3) Altnough these values are in substantial agreement with the above-mentioned measurenents, the reported values of radon flux may vary considerably from tine to time at a single sampling location as a result of differing moisture, soil characteristics, and climatological factors. 


\subsubsection{Direct Gamma Radiation}

The EGR levels measured on and adjacent to the site are shown in Figure 3-4. These measurements were made with a calibrated scintillation detector. The highest uncorrected EGR rate $(800 \mu R / h r)$ was measured between grid points (about $650 \mathrm{ft}$ east of the L.P. Anderson Building) in the area where there is no scoria cover. The uncorrected EGR levels along the boundary adjacent to the railroad were generally higher than in other areas of the site.

Off-site measurements were made on a grid system in all directions until uncorrected readings were approximately 9 to $10 \mu \mathrm{R} / \mathrm{hr}$ above the natural background level. Off-site gamma measurements taken at 100-ft intervals reached background levels about $500 \mathrm{ft}$ north, east, and west of the site. Toward the south, Dackground levels were reached within about $300 \mathrm{ft}$ of the site boundary.

\subsubsection{Windblown Contallinants}

Another radiation pathway to humans is the atmospheric dispersion and subsequent deposition of ash. Eight gamma traverses were taken along lines away from the site, as shown in Figure 3-5. A lead-collimated gamma scintillation probe was held approxinately 1 in. above the soil, and a 1 -min count was taken. The count was read out on a portable scaler. A second 1 -min count was taken in the same location with a 0.5-in.-thick lead shield inserted between the probe and the soil. The difference in the two readings, called the "delta", is an indication of the $226_{\mathrm{Ra}}$ concentration in the soil at that location. It has been determined experimentally that a delta of about 400 counts/min suggests a $226_{\mathrm{Ra}}$ concentration in soil of approximately $5 \mathrm{pCi} / \mathrm{g}$ above natural background with the system used.

The estimated $5-\mathrm{pCi} / \mathrm{g}$ contour around the site is indicated in Figure 3-5. The maximum extent of windblown contamination is about $400 \mathrm{ft}$ north of the site boundary and about $100 \mathrm{ft}$ north of the cenex boundary, while the minimum extent is about $200 \mathrm{ft}$ south of the site.

\subsubsection{Ground and Surface water Contamination}

Three surface water samples and two samples from wells were taken in the site vicinity and analyzed. The locations of these samples are snown in Figure $3-6$ and the results of the analyses are shown in Table 3-2.

The three surface water samples taken from the ponded water of the Heart River showed the gross alpha content to be less than $2 \mathrm{pCi} / 1$, while the $226_{\mathrm{Ra}}$ content was less than $0.6 \mathrm{pCi} / 1$. The $238 \mathrm{u}$ concentration ranged from 0.03 to $0.08 \mathrm{pCi} / \mathrm{l}$, and the pH of these samples was in the neutral range. A fourth 
water sample was taken from a well located less than $0.3 \mathrm{mi}$ northwest of the site, and a fifth sample was taken from a well on the site itself. The gross alpha contents of these samples were less than $2 \mathrm{pCi} / 1$, and the $226_{\mathrm{Ra}}$ content was less than $0.6 \mathrm{pCi} / 1$. The $238_{\mathrm{U}}$ concentration was less than $0.01 \mathrm{pCi} / 1$ for both samples, and the $\mathrm{pH}$ was slightly basic.

\section{4 .5 Soil Contamination}

The amount of $226_{\mathrm{Ra}}$ activity in the ash residue and the extent of leaching of radium from the ash into the soil were determined by logging drill holes in and around the site and into the soil beneath it. The radioactivity profiles were measured in these holes with a collimated Geiger-Mueller tube. Soil samples also were taken from the holes for radionetric and chemical analyses. The hole locations are shown in Figure 2-3.

Figures $3-7$ and $3-8$ show the $226_{\mathrm{Ra}}$ activity profiles in two drill holes at the Belfield ashing area. Figure 3-7 illustrates the $226_{\mathrm{Ra}}$ profile at drill hole BFND-19, located about $200 \mathrm{ft}$ east of the L.P. Anderson Building. Figure 3-8 is the profile of radium activity at drill hole BFND-22, $600 \mathrm{ft}$ east of the building and close to the end of the scoria fill. In both cases radium activity peaked about 1 to 2 ft below the surface, dropping to background at about 4 ft below the surface. Elevated activity was not detected lower than about 4 ft below the surface. To the north and west, low levels of contamination were detected at the surface or within the first foot of soil depth only. No activity was detected in drill holes south of the site. Based on gamma logs, the on-site radium activity in drill holes was found to be as high as $650 \mathrm{pCi} / \mathrm{g}$, while soil samples taken from the drill holes showed radium concentrations ranging to more than $2,000 \mathrm{pCi} / \mathrm{g}$.

\subsubsection{Off-Site Use of Contarninated Material}

Identification of locations of off-site usage of the contaminated ash was beyond the scope of this investigation and was not attempted. However, since the ash generated at the site was the final product from the ashing operation at Belfield and was shipped to Union Carbide's uranium ore processing plant in Rifle, Colorado, it was assumed that there are no locations away from the site where lignite or ash would have been used.

\subsubsection{Radon Daughter Concentrations}

Radon daughter concentrations (RDC) were measured at four locations as shown in Figure 3-9. The RDC was measured three times at each location during a single working day and then averaged to indicate a working-day average radon daughter concentration.

The maximum observed RDC was 0.008 wL in the L.P. Anderson workshop. Since the U.S. Environmental protection Agency 
interim cleanup standards for inactive uranium processing sites permit a maximum indoor RDC of 0.015 WL after remedial action, it is possible that no remedial action would be required in these structures. (4)

\subsection{REMEDIAL ACTION CRITERIA}

Title II, section 206 of $\mathrm{PL} 95-604$ required the EPA to promulgate standards for the protection of the public and the environment from radiological and nonradiological hazards associated with residual radioactive materials (as defined in the Act) at inactive uranium mill tailings and depository sites. The EPA subsequently published both interim cleanup standards (45 FR 27366) and proposed disposal standards (46 FR 2556).

\subsubsection{EPA Interim and Proposed Standards}

The interin cleanup standards and the proposed disposal standards require that remedial actions be conducted to provide reasonable assurance that:

(a) For a period of at least 1,000 yr following disposal:

(1) Radon released from the disposal site to the atmosphere would not exceed $2 \mathrm{pCi} / \mathrm{m}^{2}-\mathrm{s}$;

(2) Substances released from the disposal site to underground sources of drinking water would not contarninate the water in excess of limits described in the tabulation below; and,

(3) Substances released from the disposal site to surface waters would not contribute to contamination otherwise existing in the water.

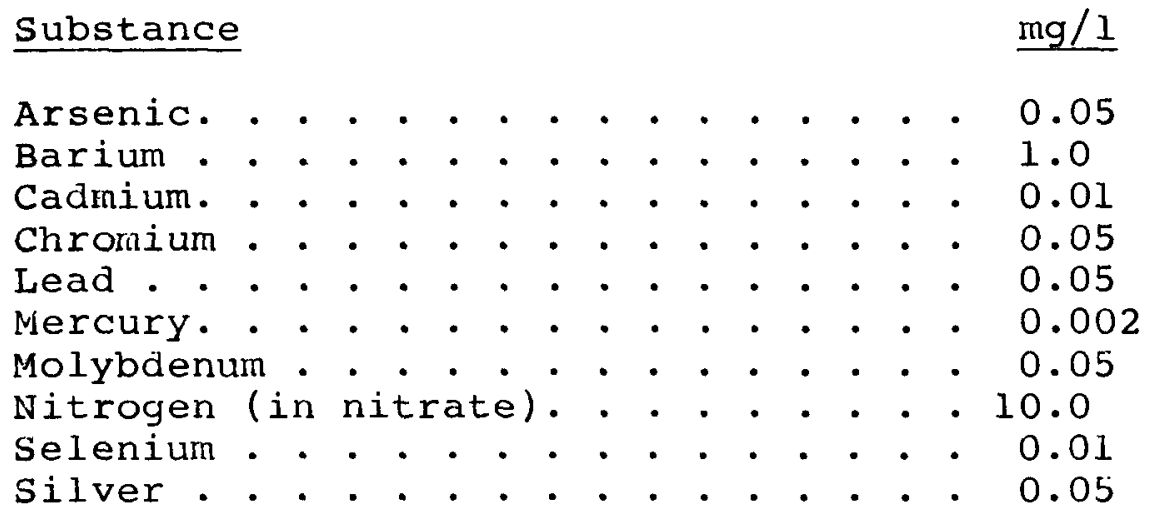


Substance

$\mathrm{pCi} / 1$

Combined $226_{\mathrm{Ra}}$ and $228_{\mathrm{Ra}} .$.
Gross alpha particle activity
(including $226_{\mathrm{Ka}}$ but excluding
radon and uranium) . . . . . . . . . . 15.0
Uranium . . . . . . . . . . . . 10.0

(b) The average concentration of $226_{\mathrm{Ra}}$ attributable to resiaual radioactive material from any designated processing site in any $5-\mathrm{cm}$ thickness of soils or other materials on open land within $1 \mathrm{ft}$ of the surface, or in any 15-cm thickness below $1 \mathrm{ft}$, shall not exceed $5 \mathrm{pCi} / \mathrm{g}$.

(c) The levels of radioactivity in any occupied or occupiable building snall not exceed either of the values specified in the listing below, because of residual radioactive materials from any designated processing site.

Average annual indoor radon decay

product concentration--including

backyround (WL) ........... 0.015

Indoor garma radiation--above

background $(\mathrm{mk} / \mathrm{hr}) . . \cdot . \cdot . \cdot . \cdot 0.02$

\subsubsection{IJRC Regulations on Uranium Mill Tailings}

In the NRC's final regulations for uranium mill licensing requirements, amendments to 10 CFR Parts 40 and 150 incorporate licensing requirements for uranium and thorium mills including tailings and wastes into the Commission's regulations.

The amendments of part 40 , section $40.2 \mathrm{a}$, include the statement:

Prior to the completion of the remedial action, the Commission will not require a license pursuant to this Part for possession of byproduct material as defined in this Part that is located at a site where milling operations are no longer active, if the site is designated a processing site covered by the remedial action program of Title $I$ of the Uranium Mill Tailings Radiation Control Act of 1973. The Comrnission will exert its regulatory role in remedial actions, primarily through concurrence and consultation in the execution of the remedial action pursuant to Title I of the Uranium Mill Tailings Radiation Control Act of 1978. 
In view of the foregoing and since under provisions of PL 95-604 a site on which tailings have been stabilized must be maintained under a license issued by the NRC, all uranium mill tailings disposal sites under PL 95-604 may eventually be subject to the criteria set out in Appendix A to Part 40. The criteria pertaining to tailings and waste disposal and stabilization that may apply in whole, or in part, to remedial action activities under PL 95-604 are summarized as follows:

Criterion 1 - The disposal site selection process should be an optimization to the maximum extent reasonably achievable for long-term isolation of the tailings from man, considering such factors as remoteness, hydrologic and other natural characteristics, and the potential for minimizing erosion.

Criterion 2 - To avoid proliferation of small waste disposal sites and thereby reduce perpetual surveillance obligations, with certain qualifications, byproduct material from in situ extraction operations and wastes from small remote above-ground extraction operations shall be disposed of at existing large mill tailings disposal sites.

Criterion 3 - The prine option for disposal of tailings is placement below grade. Where this is not practicable, it must be demonstrated that an above-grade disposal program will provide reasonably equivalent isolation of tailings from natural erosional forces.

Criterion 4 - If tailings are located above ground, stringent siting and design criteria should be adhered to. Factors to be considered include the following:

(a) Minimization of upstream catchment area

(b) Topographic features for wind protection

(c) Relatively flat embankment slopes

(d) Self-sustaining vegetative or riprap cover

(e) Earthquake impact avoidance

(f) Promotion of soil deposition

Criterion 5 - Steps shall be taken to reduce seepage of toxic materials into ground water to the maximum extent reasonably achievable. 
Criterion 6 - Sufficient earth cover, but not less than $3 \mathrm{~m}$, shall be placed over tailings or wastes at the end of milling operations to result in a calculated reduction in surface exhalation of radon from the tailings or wastes to less than $2 \mathrm{pCi} / \mathrm{m}^{2}-\mathrm{s}$ above natural background levels. Direct gamma exposure from the tailings or wastes should be reduced to background levels.

Criterion 11-Provisions are set out for eventual transfer of ownership of the tailings to the state or to the United States.

Criterion 12 - The final disposition of tailings or wastes at milling sites should be such that ongoing active maintenance is not necessary to preserve isolation. Annual inspections should be conducted by owners.

EPA proposed and interim environmental standards for uranium mill tailings stabilization are generally consistent with the NRC proposed criteria as given above. However, they add the important further condition that the stabilization should be designed to provide reasonable assurance of remaining effective for at least $1,000 \mathrm{yr}$.

\subsection{POTENTIAL HEALTH IMPACT}

3.6.1 Assumptions and Uncertainties in Estimating Health

\section{Effects}

Since radiation exposure from $222 \mathrm{Rn}$ progeny is expressed in terms of workiny levels (WL) and working level months (WLM), total population exposures as well as health risk estimates are based upon these units; i.e., person-WLM. Exposures and resulting health effects are often expressed in terms of rems; however, estimates of the WLM-to-rem conversion factor for internal lung exposure to alpha particles from $222 \mathrm{Rn}$ progeny are observed to vary by over an order of magnitude. (5) Presently, there are significant differences of opinion related to the choice of an appropriate conversion factor. Consequently, disagreements of calculated health effects from RDC occur when these effects are based on the rem.

The BEIR-III(6) risk estimator for lung cancer is based only on the absolute model since the relative risk model is not considered valid.(7)

The BEIR-III risk estimators for radon daughters are agedependent, with the age specified as the age at the diagnosis of cancer. The minimal latent period following exposure is also age-dependent. The following values can be determined: 
Ninimal

Latent Period

From Age at

\begin{tabular}{c} 
Age \\
(yr) \\
\hline
\end{tabular}

$0-14$

$15-34$

$35-49$

$50-65$

$66-75$
Exposure

(yr)

25

15

10

10

10

\author{
Excess Risk \\ at Age of \\ Diagnosis \\ (cancers per yr \\ per $10^{6}$ person WLM)
}

0

0

9

18

42

These risk values are expressed in terms of WLM using the BEIR-III recommended conversion factor of 6 rem per WLM. These risk estimators are based on combined estimates for uranium rniners and fluorspar miners; no data exist that indicate whether these values may be used for groups irradiated in childhood. Nevertheless, in the treatment below they are conservatively assumed to apply to the population at large.

The BEIR-III report does not discuss plateau periods. However, some data presented in the report indicate cancers are still being detected as much as $50 \mathrm{yr}$ after the period of exposure. Therefore, it is reasonable to assume that a lifetime plateau to age 75 may be applicable.

The age-dependent excess risks presented in the BEIR-III report must be adjusted, when applied to the population at large, to account for the fact that the breathing rate of miners on the job is about 1.9 times greater than that of the general population. (8) Since exposure is considered proportional to the breathing rate, the exposure (and hence the excess risk) of the general population would be smaller by this same factor.

The cumulative risk estimator is obtained from the BEIR-III data adjusted for breathing rate by determining cancer risks for each year following an exposure. These risks are summed for the years between age at exposure and age 75. The contribution to the cumulative risk estimator from each age group is weighted by the respective fractions of the U.S. population found in those age groups.(9) For the lifetime plateau to age 75, no cancers were assumed to occur in the years subsequent to age 75 . The following cumulative risk estimator for the population at large is obtained using a lifetime plateau to age 75 and weighting by the age distribution of the U.S. population:

150 cancers per yr/106 person - (WLM continuous) 
Because of the many factors that contribute to natural biological variability and of the many differences in exposures among miners and among the population at large, this risk estimator is considered to have an uncertainty factor of about 3 .

For the purpose of this assessment, equivalent working levels inside structures are determined from the radon concentration assuming a 50\% equilibrium condition. This yields the following conversion factor:

$$
1 \mathrm{pCi} / 1 \text { of } 222_{\mathrm{Rn}}=0.005 \mathrm{WL}
$$

It is assumed that the component of indoor radon concentration due to radon originating from the pile is equal to the corresponding outdoor concentration component at that point. However, the total concentration of radon progeny is higher indoors owing to reduced ventilation, and to other sources such as building materials.

The exposure rate in terms of WLM/Yr can be obtained from a continuous 0.005 -WL concentration as follows:

$$
(0.005 \mathrm{WL})\left(8766 \frac{\mathrm{hr}}{\mathrm{Yr}}\right)\left[\frac{1 \mathrm{WLM}}{(1 \mathrm{WL})(170 \mathrm{hr})}\right]=0.25 \frac{\mathrm{WLM}}{\mathrm{yr}^{\mathrm{r}}}
$$

The risk estimator used for continual exposure to gamma radiation is expressed as:(10)

$72 * \dot{\mathrm{D}}+0.8 * \dot{\mathrm{D}}^{2}$ cancers per $y \mathrm{r} / 10^{6}$ person rems/yr-continuous

where $\dot{D}$ is the dose rate in rem/yr. In this assessment it is assumed that a gamma exposure of $1 \mathrm{R}$ in air is equivalent to a dose of 1 rem in tissue.

\subsubsection{Health Effects}

The health effects due to the on-site ash waste material were calculated using a $222_{\mathrm{Rn}} \mathrm{tlux}$ of $200 \mathrm{pCi} / \mathrm{m}^{2}-\mathrm{s}$, which was calculated using diffusion theory and the assumption that the physical properties of ash are similar to those of uranium tailings. Even though the calculated value for radon flux appears much larger than the measured values, it is considered 
a more defensible estimate of the radon release rate since measurements of radon flux to date have been made only at a few points in time and give no suggestion of the magnitude of annual variations. In the absence of this information, the conservative estimate was chosen as the basis for health effect calculations.

The transport of radon from the ash was modeled using a Gaussian plume model, meteorology characteristics of the area, and population distribution surrounding the ash as a function of the radius and direction from the center of the ash waste area. The ash area was modeled as a vertical cylinder with an area equivalent to the actual surface at natural grade.

The population distribution within $2 \mathrm{mi}$ of the edge of the site was developed using 1980 census statistics and other population information for the past decade. This distribution includes all residents close enough to the site to be noticeably exposed to radon exhalation from the ash, as described in Chapter 4 .

The three population projections used to estimate the cumulative health impacts attributable to the on-site ash were the 0.68 constant growth rate and the 2.38 and $4 \%$ declining growth rates. All three growth projections assume that the population is distributed in the same proportions as those reflected in Table 4-1. The slowest growth rate, $0.6 \% / y r$, is assumed to represent the growth expected if no energy or other development were to occur. In this case, the population would increase about $16 \%$ in $25 \mathrm{yr}$.

If moderate energy or other developments were to occur in the area, then a 2.38 declining growth rate is assumed to prevail and is taken to be most likely. The population thus would increase by $20 z$ during the first $10 \mathrm{yr}$, then level off to approximately 2,200 residents.

The 4\% declining growth rate was assumed to prevail if energy resources were extensively developed in the area. At this rate, the population would be 1.5 times the present amount after $15 \mathrm{yr}$ and would increase to about 2,755 people by the year 2005 .

Table 3-3 presents the estimated health impacts from the on-site ash for 0 to $2 \mathrm{mi}$ from the edge of the site, based on the estimated 1980 population distribution presented in Table 4-1. The cumulative health effects for the three growth scenarios considered for Belfield also are included. In Table 3-3, the health effects due to radon from the on-site ash are shown to be less than $1 \%$ of those caused by background radon for the vicinity within $2 \mathrm{mi}$ of the edge of the site.

Total predicted outdoor $222 \mathrm{Rn}$ concentration (resulting from radon release from the ash) is shown as a function of distance 
in the predominant downwind direction from the center of the ash area in Figure 3-10. The predicted $222 \mathrm{Rn}$ concentration at $100 \mathrm{ft}$ from the edge of the site is almost 1.7 times background levels, but at about $0.3 \mathrm{mi}$ from the edge of the site, the total predicted radon concentration has dropped to background levels.

Figure 3-1l shows the estimated lung cancer risk per year from continuous exposure to radon as a function of distance in the predominant downwind direction from the edge of the site. The curve shows that the risk for developing lung cancer attributable to radon released from the ash is about 1.1 times the natural occurrence from all causes at a distance of $100 \mathrm{ft}$ from the edge of the ash area, but declines to the natural occurrence within $0.3 \mathrm{mi}$.

Based on the average external gamma radiation (EGR) levels on site of $120 \mu \mathrm{R} / \mathrm{hr}$, it was estimated that the excess risk of death by radiation-induced cancer is about 0.0001 health effects/person/yr, for continual exposure. For a crew of about 10 persons on site about $2,000 \mathrm{hr} / \mathrm{yr}$, the estimated health effect rate is about 0.0002 health effects/yr under present conditions. This rate is comparable to that produced among the population in the surrounding area by radon attributable to the ashing site.

If the same 10 workers at the site were exposed only to background levels of EGR, their risk of radiation-induced cancer would be about $10 \%$ of that attributable to EGR levels from the ashing site.

\subsection{NONRADIOACTIVE POLLUTANTS}

Besides the radioactive contaminants, the ashing site contains other potentially toxic nonradioactive materials. Chemical analyses of soil samples from auger holes in the Belfield site area showed arsenic concentrations ranging as high as 565 pprn. The water sample taken directly north of the site also contained an unusually high concentration of arsenic, as shown in Table 3-2. The data are insufficient to implicate or dismiss the site as the source of this contamination. 


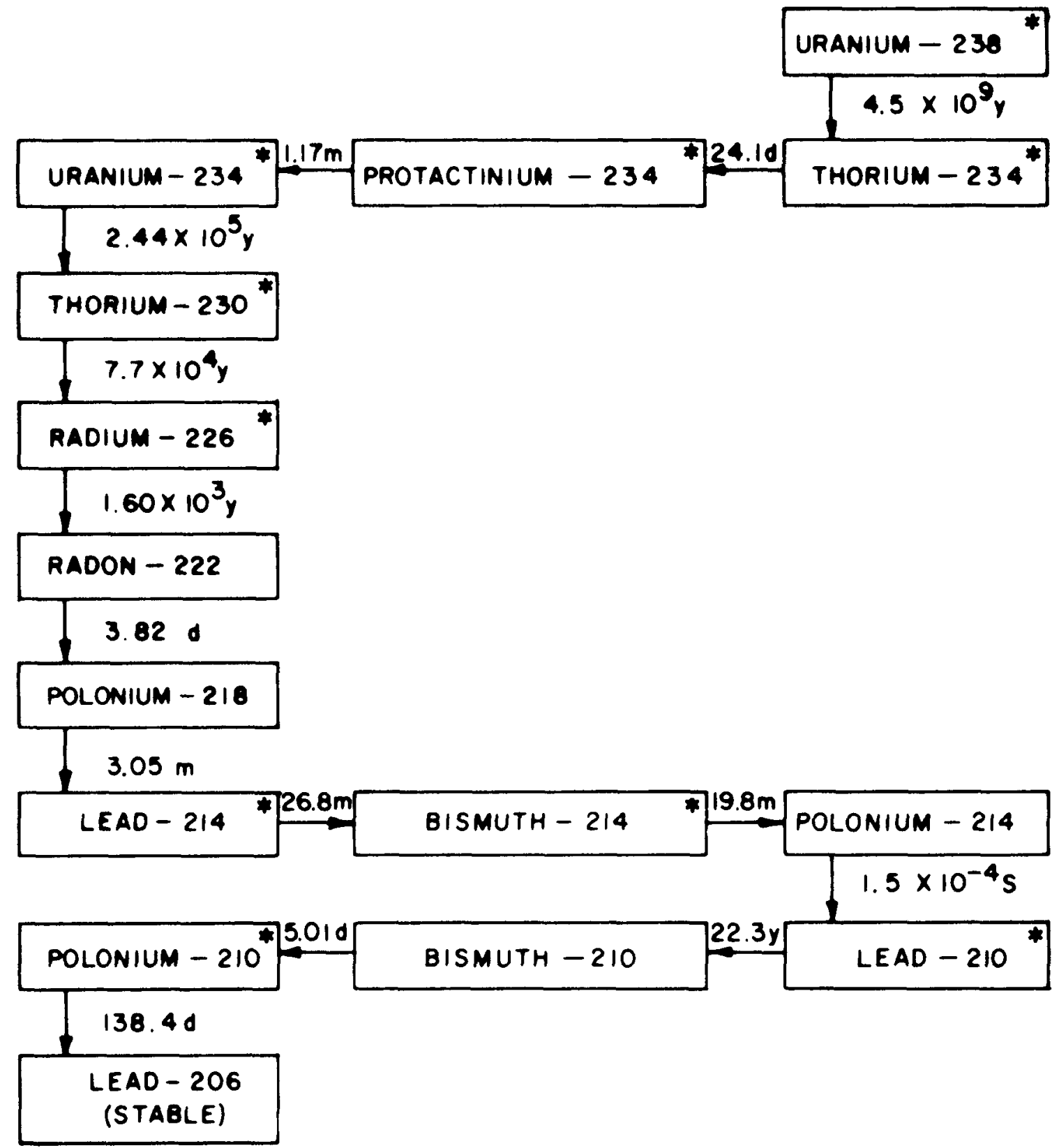

NOTE

VERTICAL DIRECTION REPRESENTS ALPHA IJECAY, HORIZONTAL DIRECTION INDICATES BETA DECAY TIMES SHOWN ARE HALF LIVES. ONLY THE DOMINANT DECAY MODE IS SHOWN

* also gamma emitTers

FIGURE 3-1. RADIOACTIVE DECAY CHAIN OF URANIUM-238 


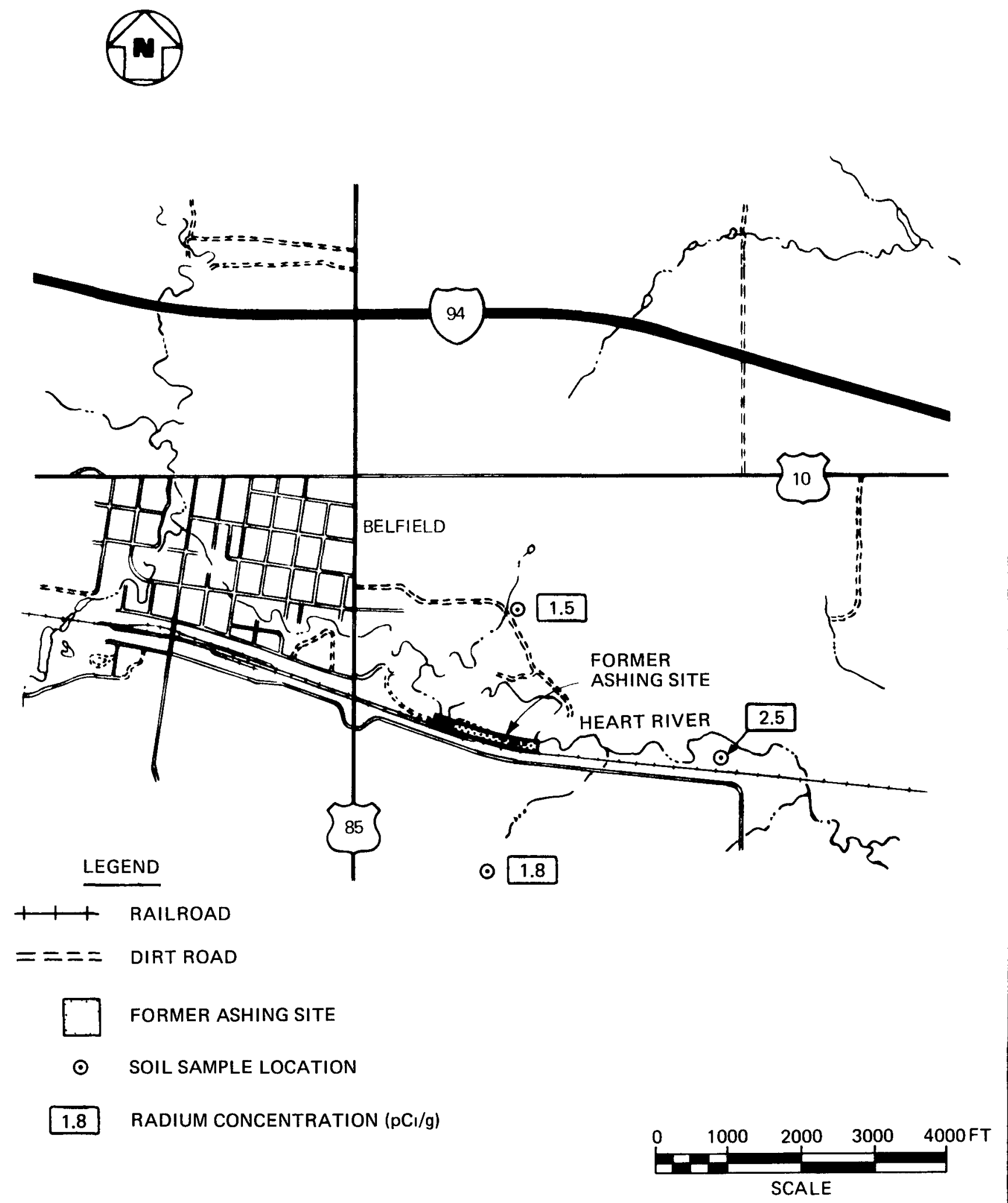

FIGURE 3-2. BACKGROUND SOIL SAMPLE LOCATIONS 


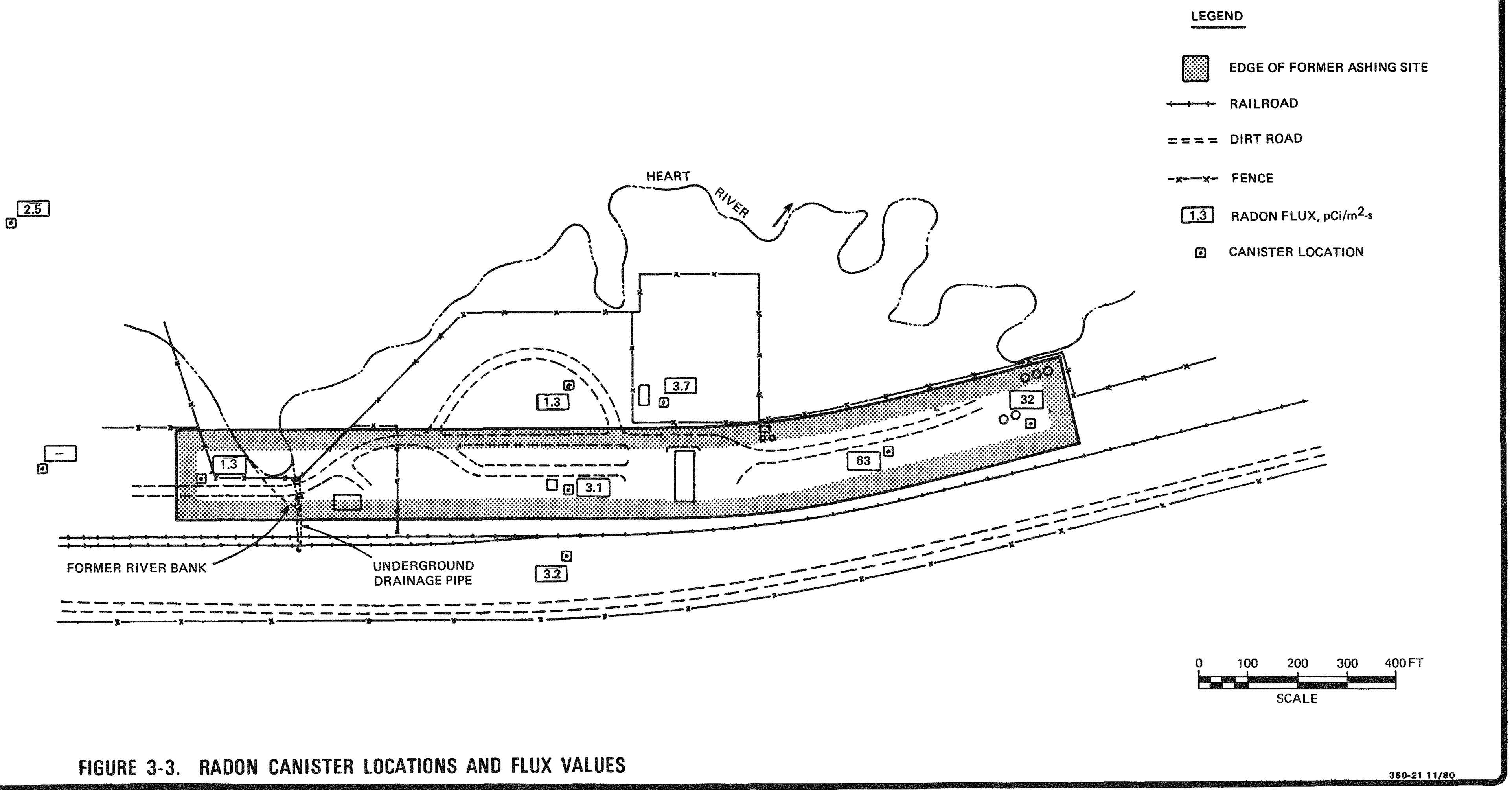


LEGEND

$\square$ EDGE OF FORMER ASHING SITE $==:==$ DIRT ROAD

\#HAILROAD

\section{$-x-x-$ FENCE}

- GROSS GAMMA LEVELS IN $\mu R / H R$ (INCLUDING BACKGROUND)
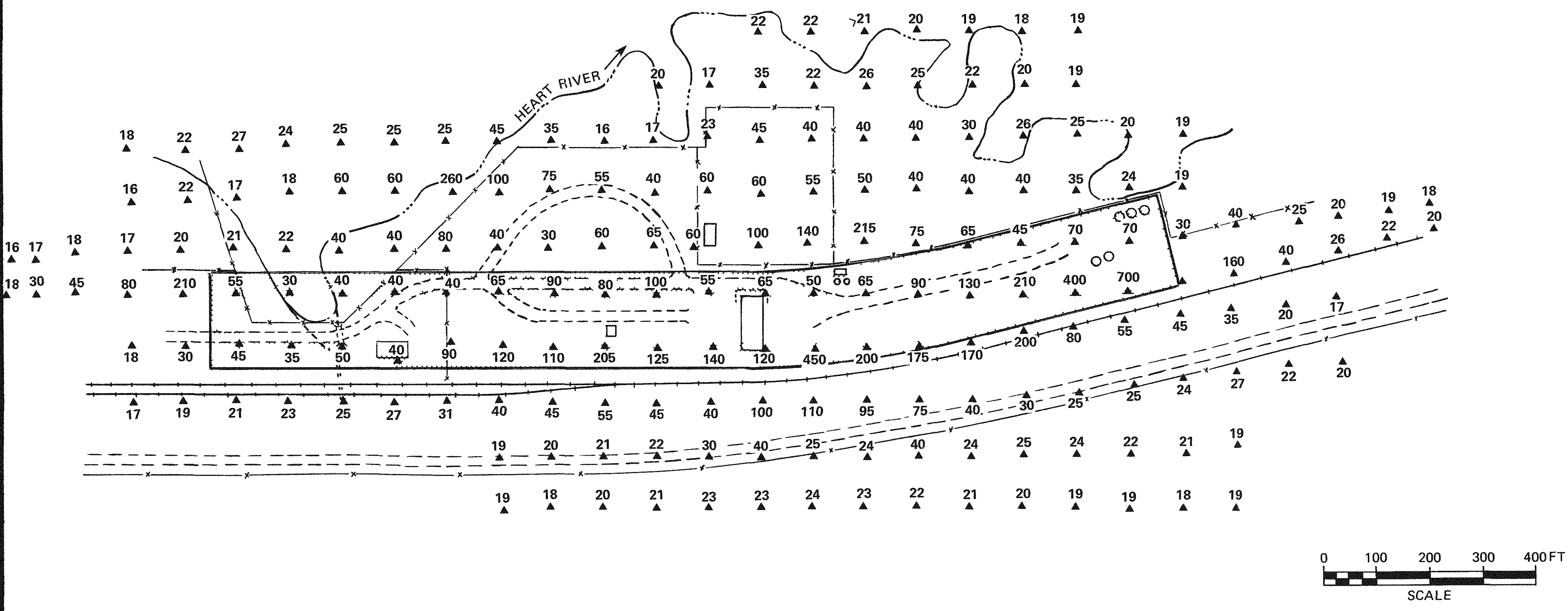
NOTE

NUMBERS REPRESENT 'DELTA' READINGS AS EXPLAINED IN PARAGRAPH 3.4 .3

\section{LEGEND}

EDGE OF FORMER ASHING SITE

๘ RAILROAD

$====$ DIRT ROAD

$\rightarrow$ FENCE

$\uparrow$ MEASURE POINTS (CPM)

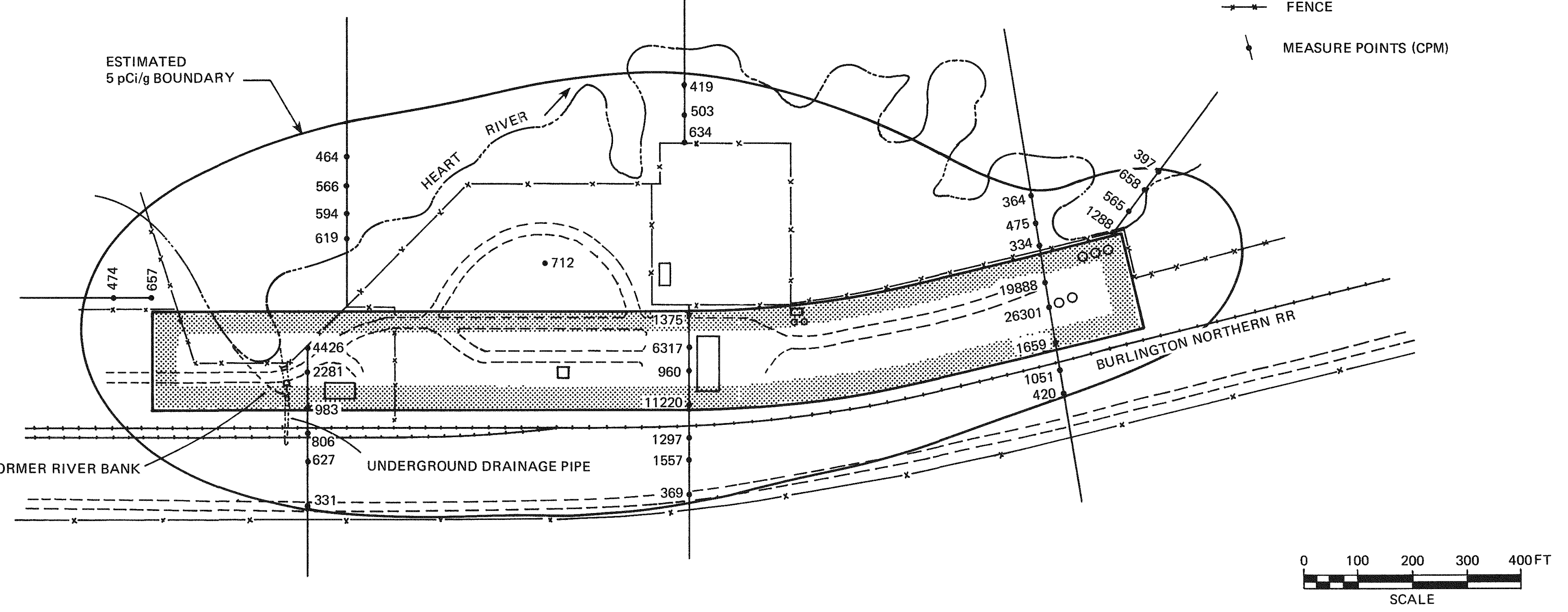


$\otimes \quad$ SURFACE WATER SAMPLE
LOCATION \& IDENTIIICATION NO.

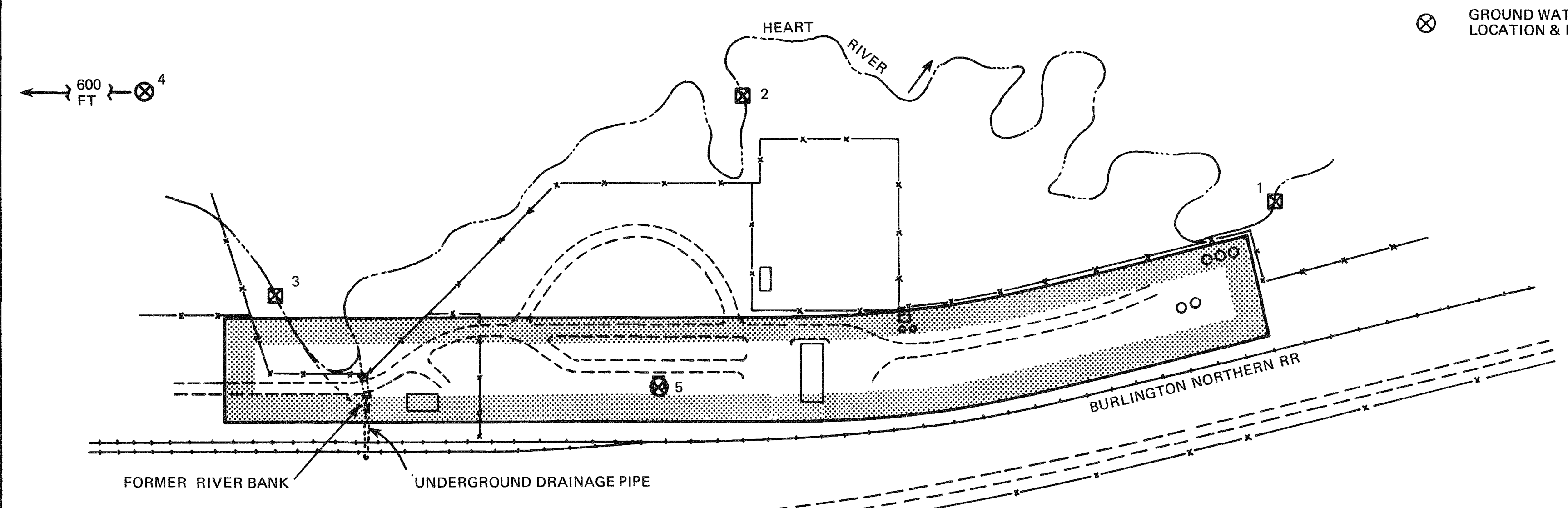

ニニニニニニニニニニニニニニニニニニニニ-

$\underbrace{100 \quad 300 \quad 400 F T}_{\text {SCALE }}$ 


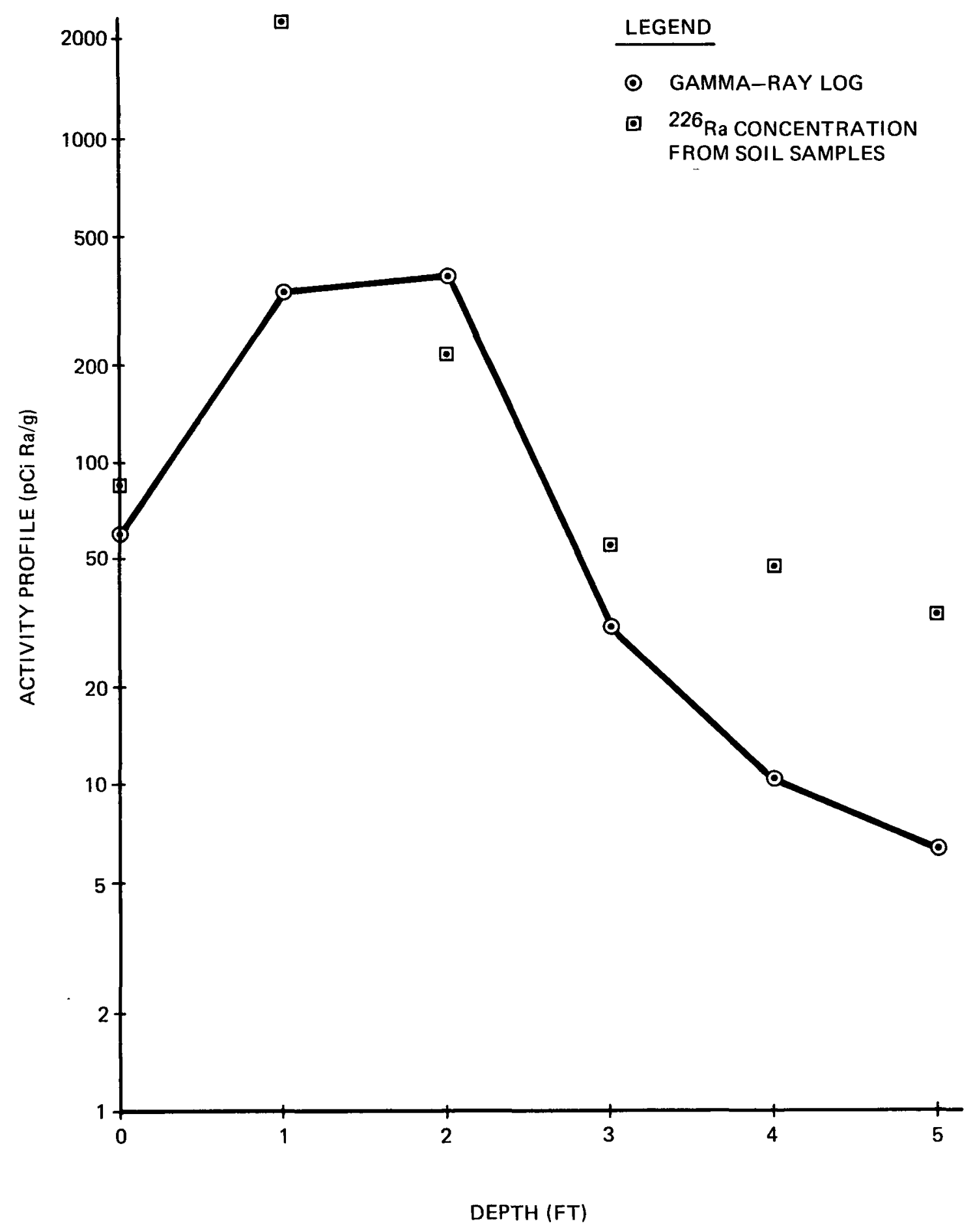

FIGURE 3-7. RADIOMETRIC PROFILE AT DRILL HOLE BFND-19 


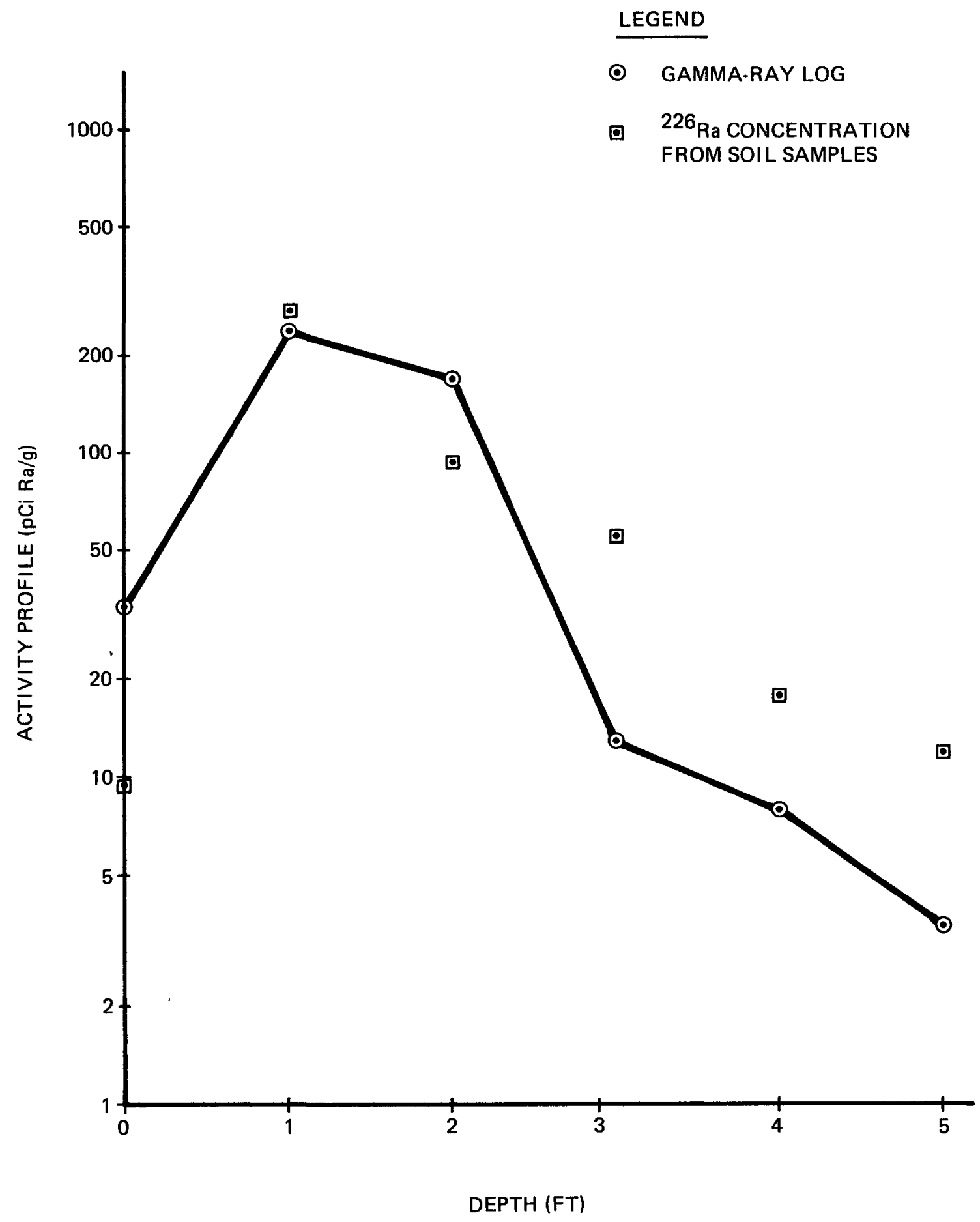

FIGURE 3-8. RADIOMETRIC PROFILE AT DRILL HOLE BFND-22 


\section{NOTE}

NUMBERS SHOWN REPRESENT RADON DAUGHTER CONCENTRATION

LEGEND

EDGE OF FORMER ASHING SITE 千, RAILROAD

$-x-x-$ FENCE

$====$ DIRT ROAD

$\underset{-600 \mathrm{FT}}{0.002}$

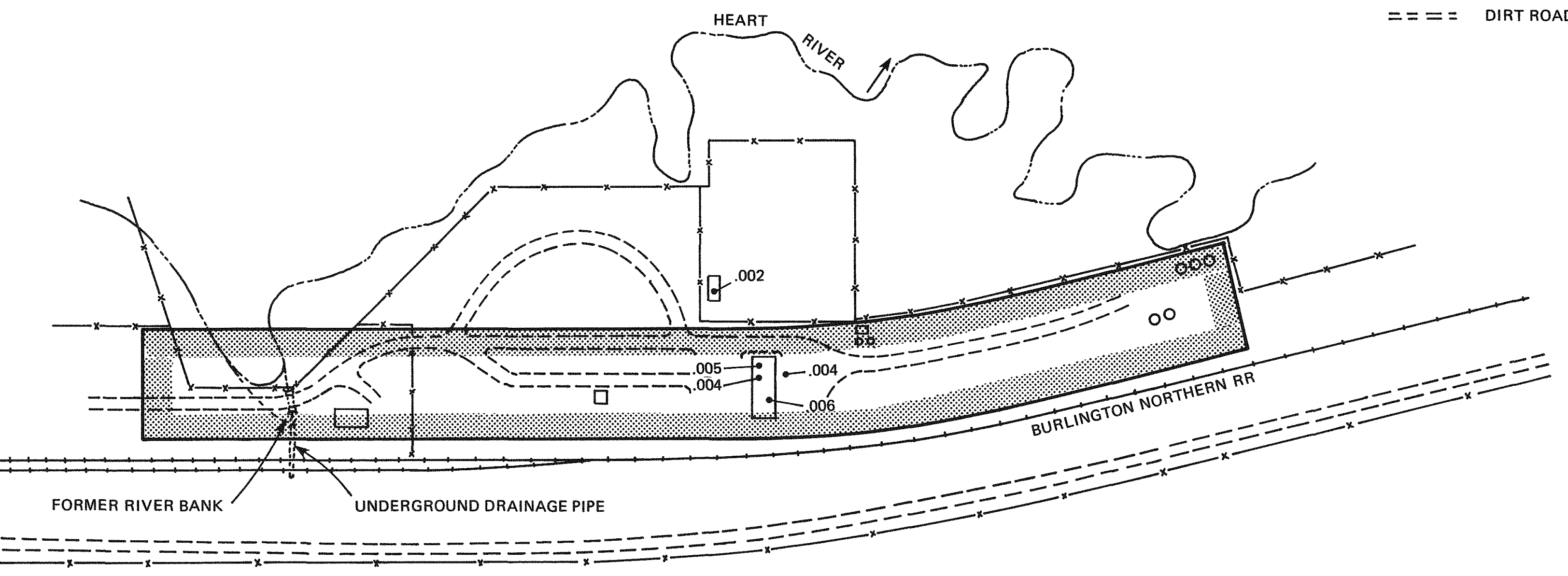

$\stackrel{0}{100 \quad 200 \quad 300 \quad 400 \mathrm{FT}}$ 

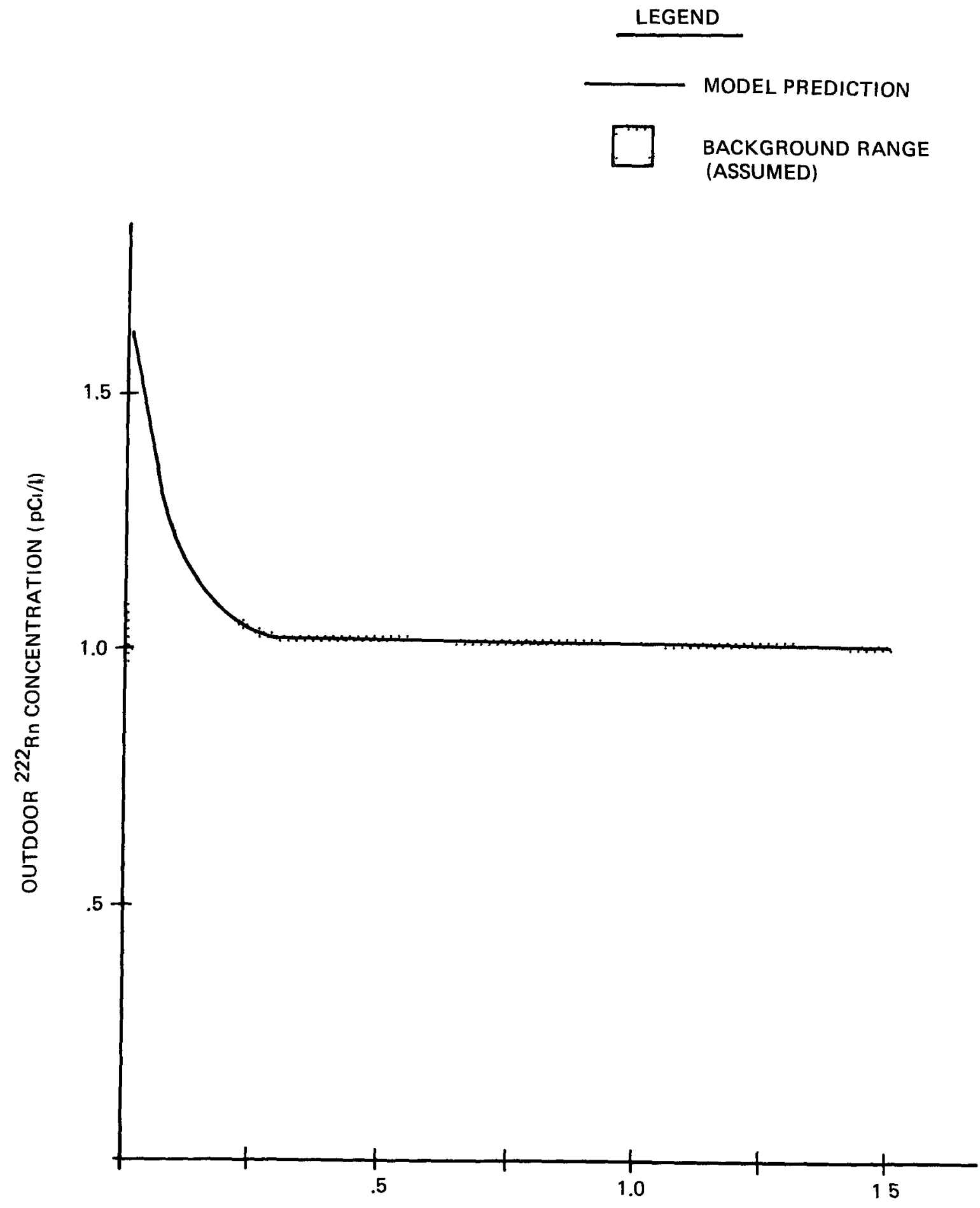

DISTANCE FROM EDGE OF ASHING SITE (MI)

\section{FIGURE 3-10. REDUCTION OF OUTDOOR ${ }^{222}$ Rn CONCENTRATION WITH DISTANCE FROM EDGE OF ASHING SITE}




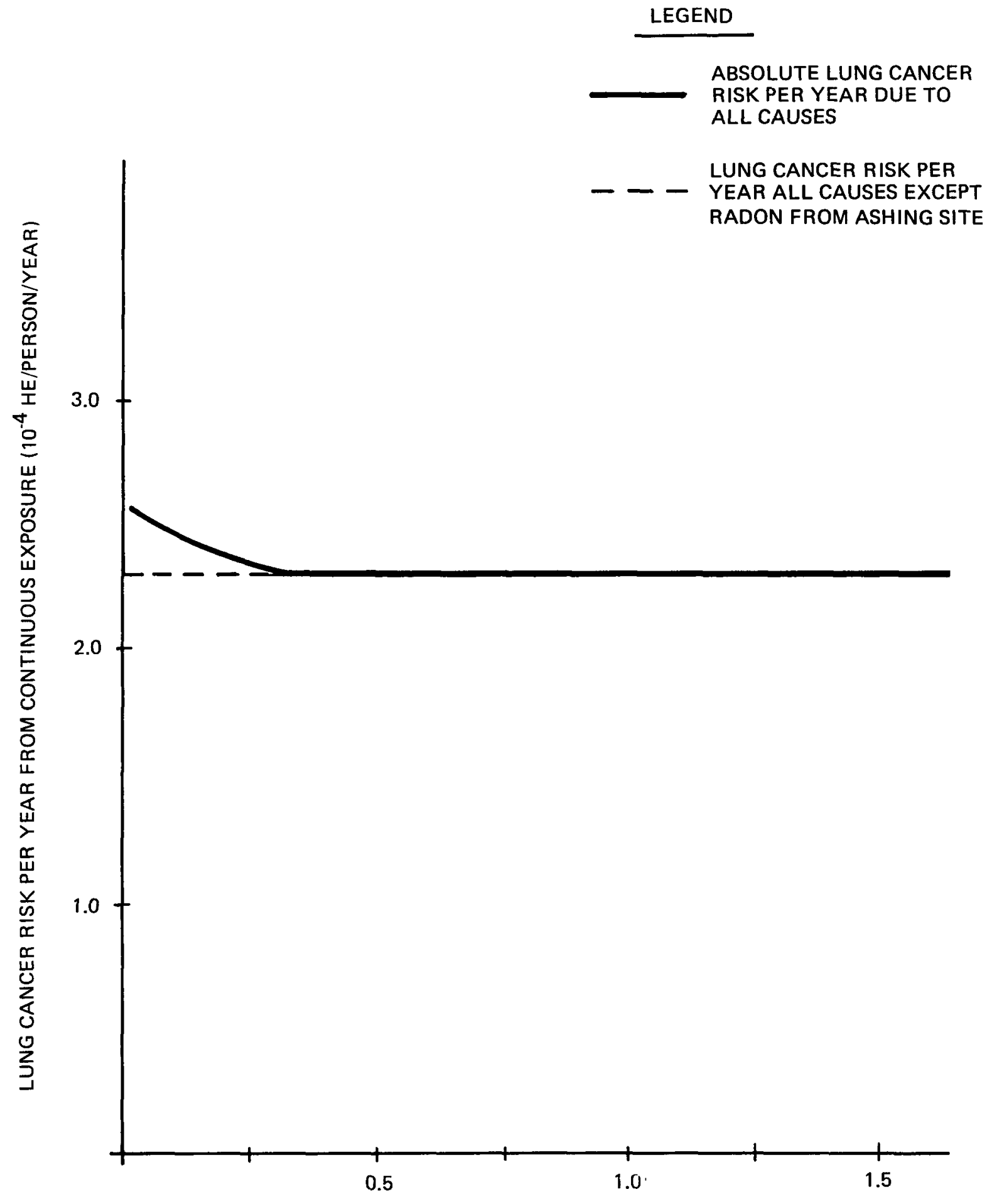

DISTANCE FROM EDGE OF ASHING SITE (MI)

FIGURE 3-11. LUNG CANCER RISK FROM CONTINUOUS EXPOSURE TO RADON GAS 
TABLE 3-1

NOTATIONS AND ABBREVIATIONS USED IN CHAPTER 3

Isotope - A particular type of element, differing by nuclear characteristics, identified by the atomic mass number given after the element name; e.g., Radiurn-226.

Isotope Abbreviations:

$$
\begin{aligned}
238 \mathrm{U} & =\text { Uranium-238 } \\
234 \mathrm{Th} & =\text { Thorium-234 } \\
232 \mathrm{Th} & =\text { Thorium-232 } \\
234 \mathrm{~Pa} & =\text { Protactinium-234 } \\
226 \mathrm{Ra} & =\text { Radium-226 } \\
222 \mathrm{Rn} & =\text { Radon-222 } \\
218 \mathrm{Po} & =\text { Polonium-218 } \\
214 \mathrm{~Pb} & =\text { Lead-214 } \\
214 \mathrm{Bi} & =\text { Bismuth- } 214 \\
40_{\mathrm{K}} & =\text { Potassium }-40
\end{aligned}
$$

Radiations :

alpha particle

beta particle

gamma rays

half-life $\left(\mathrm{T}_{1 / 2}\right)$

working level (WL)

working level

month (WLM) helium nucleus; easily stopped with thin layers of material, all energy deposited locally.

electron; penetrates about $0.2 \mathrm{~g} / \mathrm{cm}^{2}$ of material.

electromagnetic radiation; similar to $X$-rays, and highly penetrating.

time required for half the radioactive atoms to decay.

measure of potential alpha energy per liter of air from any combination of short-lived radon daughters $\left(1 \mathrm{WL}=1.3 \times 10^{5} \mathrm{MeV}\right.$ of alpha energy).

exposure to air containing a RDC of 1 wL for a auration of $170 \mathrm{hr}$. 
roentgen $(R)$

$\mu \mathrm{R} / \mathrm{hr}$

rad

picocurie (pCi)

HeV

rem that quantity of gamma radiation which yields a charge deposition of $2.53 \times 10^{-4}$ coul/kg air. This is equal to the energy deposition of $88 \mathrm{ergs} / \mathrm{g}$ of dry air or $93 \mathrm{ergs} / \mathrm{g}$ of tissue.

$10^{-6}$ roentgen/hr.

energy deposition of 100 ergs/g of material.

unit of activity ( 1 pCi = 0.037 radioactive decays/sec or $2.2 \mathrm{~min}$ ).

unit of energy; 1 MeV= $1.6 \times 10^{-6} \mathrm{erg}$.

unit of energy deposition in man; 1 rem $=1$ rad $x$ quality factor; the quality factor = 20 for alpha particles.

Note: Also see definitions of terms in Glossary. 
TABLE $3-2$

SURFACE AND GROUND WATER SAMPLE RESULTS

\begin{tabular}{|c|c|c|c|c|c|c|}
\hline $\begin{array}{l}\text { Sample } \\
\text { No. }\end{array}$ & Location $^{a}$ & $\begin{array}{c}\text { Gross } \\
\text { Alpha } \\
(\mathrm{pCi} / \mathrm{l}) \\
\end{array}$ & $\begin{array}{l}226_{\mathrm{Ra}} \\
(\mathrm{pCi} / 1) \\
\end{array}$ & $\begin{array}{l}238 \mathrm{U} \\
(\mathrm{pCi} / 1) \\
\end{array}$ & $\mathrm{pH}$ & $\begin{array}{l}\text { Arsenic } \\
\text { (ppm) }\end{array}$ \\
\hline 1 & $\begin{array}{l}\text { East of Site } \\
\text { in Heart River }\end{array}$ & $<2.0$ & $<0.6$ & 0.04 & 7.60 & 0.008 \\
\hline 2 & $\begin{array}{l}\text { North of Site } \\
\text { in Heart River }\end{array}$ & $<2.0$ & $<0.6$ & 0.03 & 7.40 & 0.041 \\
\hline 3 & $\begin{array}{l}\text { West of Site } \\
\text { in Heart River }\end{array}$ & $<2.0$ & $<0.6$ & 0.08 & 6.90 & 0.002 \\
\hline 4 & $\begin{array}{l}\text { Santa Fe Well } \\
\text { West of Site }\end{array}$ & $<2.0$ & $<0.6$ & $<0.01$ & 8.60 & $<0.001$ \\
\hline 5 & $\begin{array}{l}\text { L.P. Anderson } \\
\text { Well On Site }\end{array}$ & $<2.0$ & $<0.6$ & $<0.01$ & 7.80 & 0.002 \\
\hline
\end{tabular}

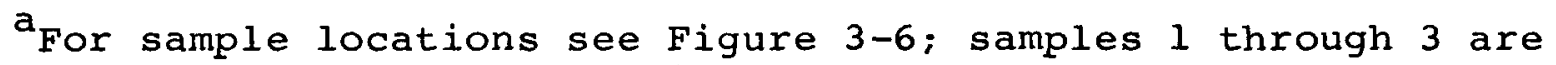
surface water samples, while samples 4 and 5 are ground water samples.

${ }^{b}$ Interim Primary Drinking Water Regulations:

Total Radium (Gross Alpha) $--5 \mathrm{pCi} / 1$

Arsenic--0.05 ppm 
TABLE 3-3

ESTIMATED HEALTH IMPACT FROM BELFIELD ASH

FOR AN AREA O TO 2 MILES FROM EDGE OF THE SITE

\begin{tabular}{|c|c|c|c|}
\hline Time Period & $\begin{array}{l}\text { Population } \\
\text { (Persons) }\end{array}$ & $\begin{array}{c}\text { Total } \\
\text { Ashing Site- } \\
\text { Induced } \\
\text { RDC Health } \\
\text { Effects/Yr } \\
\end{array}$ & $\begin{array}{l}\text { Background } \\
\text { RDC Health } \\
\text { Effects/Yr }\end{array}$ \\
\hline 1980 & 1,650 & 0.00025 & 0.058 \\
\hline $\begin{array}{l}2005 \text { ( } 0.68 \text { constant } \\
\text { growth rate) }\end{array}$ & 1,915 & 0.00025 & 0.075 \\
\hline $\begin{array}{l}2005(2.3 \% \text { declining } \\
\text { growth rate) }\end{array}$ & 2,220 & 0.00033 & 0.083 \\
\hline $\begin{array}{l}2005 \text { ( } 48 \text { declining } \\
\text { growth rate) }\end{array}$ & 2,755 & 0.00042 & 0.100 \\
\hline
\end{tabular}

Growth Projection

$0.6 z$ constant growth rate

2.3 declining growth rate

48 declining growth rate $^{\mathrm{b}}$
25-Yr Cumulative RDC Health Effects

Ashing

Site-Induced $\quad$ Background $^{\mathrm{a}}$

$0.006 \quad 1.6$

$0.008 \quad 1.8$

$0.008 \quad 2.1$

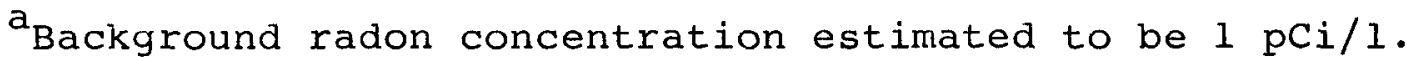

$\mathrm{b}_{\text {Declines }}$ linearly from its initial value to zero in $25 \mathrm{yr}$ and remains constant at zero thereafter. 
1. M.E. Wrenn, H. Spitz, and N. Cohen; "Design of a Continuous Digital Output Environmental Radon Monitor"; IEEE Transactions on Nuclear Science; Vol NS-22; Feb 1975.

2. R.J. Countess; "222Rn Flux Measurement with a Charcoal Canister"; Health Physics; Vol 31, p. 455; 1976.

3. "Uranium Mill Tailings Site Visits and Preliminary Health Impact Evaluation"; prepared for Bendix Field Engineering Corporation; Ford, Bacon \& Davis Utah Inc.; Salt Lake City, Utah; Oct 17, 1979.

4. "Interim Cleanup Standards for Inactive Uranium Processing Sites"; Federal Register; Vol 45, No. 79, p. 27366; Apr 2, 1980 .

5. A.K.M.M. Haque and A.J.L. Collinson; "Radiation Dose to the Respiratory system Due to Radon and Its Daughters"; Health Physics; Vol 13, p. 431; 1967.

6. "The Effects on Populations of Exposure to Low Levels of Ionizing Radiation: 1980"; Report of Advisory Committee on Biological Effects of Ionizing Radiation; NAS, National Research Council; 1980 .

7. B.L. Cohen; "The BEIR Report Relative Risk and Absolute Risk Models for Estimating Effects of Low Level Radiation"; Health Physics; Vol 37, p. 509; 1979.

8. "Indoor Radiation Exposure Due to Radium-226 in Florida Phosphate Lands"; U.S. Environmental Protection Agency; Washington, D.C.; EPA 520/4-78-013; July 1979.

9. Statistical Abstract of the United States; 100th Edition; p. 29, Table 29 .

10. "Health Effect Risk Estimators for Radon Daughters"; report to Ford, Bacon \& Davis Utah Inc., by Rogers and Associates Engineering Corp.; Jan 1981.

11. Federal Register, Part II; EPA Interim Primary Drinking Water Regulations; EPA; July 9, 1976. 
CHAPTER 4

SOCIOECONOMIC AND LAND USE IMPACTS 
Belfield is $19 \mathrm{mi}$ west of Dickinson, North Dakota. Dickinson is the largest city in southwestern North Dakota and is the principal city of the Roosevelt-Custer Planning District (Stark, Bowman, Adams, Billings, Dunn, Golden Valley, Hettinger, and slope Counties). Dickinson is also the geographical center of the region, a hub of transportation routes, and the county seat of stark county. The Fort Berthold Indian Reservation lies northeast of this District. The layout of Belfield and its relationship to the former ashing site are shown in Figure 2-2.

\subsection{SOCIOECONOMIC BACKGROUND}

Belfield was founded as a rail center in the 1880's, and the area developed on an agricultural economy base. Economic development in the Belfield area has been minimal in recent years with the bulk of the projects undertaken being related to energy. However, energy development greatly intensified in the area from 1976 to 1977 with the discovery of the Little Knife oil Field in northeastern Billings county and southwestern Dunn County. The potential for future coal-, oil-, and gas-related projects exists throughout the entire area.

The Local Development Corporation has been formed in Belfield in an attempt to attract needed new business and professional personnel.

Ethnically, the inhabitants of Belfield are predominantly Caucasian, with a minority of Mexican-Americans and Native Americans. Educational attainment is comparable with that of the nation at large. However, the median income in Belfield is relatively low. Most workers are employed primarily in areas related to agriculture, sales, and services. Farmers and farm laborers represent a majority of the populace in terms of their vocations. Today, Belfield is a community operating from an agricultural base but is steadily shifting toward energy development and associated activities.

\subsection{POPULATION ESTIMATES}

The population growth of Belfield and Stark County over the past two decades is summarized in Table 4-1. The census figures indicate that in 1960 there were 1,060 inhabitants in Belfield and 18,451 in stark County. In 1970, the census indicated that these populations had increased to 1,130 for Belfield and 19,613 for stark County. These figures represent increases of 
between 6 and $7 \%$ over a 10-yr period, or effective annual growth rates of about $0.68 / y^{r}$ for both the city and the county.

The preliminary 1980 census figures indicate that the population of Belfield increased about 58 over the decade (0.58 effective annual growth rate) to 1,188 , while stark County's population increased by about 218 over the decade ( 1.98 effective annual growth rate) to $23,703$. (1) However, growth indicators such as telephone hookups and housing starts suggest that Belfield has experienced considerable growth during the later years of the decade. City officials estimate on the basis of these indicators that the population of Belfield increased about 468 over the past decade ( 3.98 effective annual growth rate) to a total of approximately 1,650 people.(2)

The population distribution as a function of distance and direction from the site is estimated in Table 4-2. Presently, 21 employees work for the L.P. Anderson Construction Company, which is located on the site. A field survey indicated an additional 100 people reside or work within a 0.5-mi radius of the site. The remainder of the population distribution is based on an equal proportioning of the people throughout the city boundaries.

Population projections for Belfield indicate that the area will continue to experience rapid growth in the future as a result of the rich oil, coal, and gas resources in the area and the need to develop these resources for domestic energy. A new gas pipeline operation will bring approximately 160 seasonal residents and 50 permanent residents to Belfield.

A population projection performed by the Roosevelt-Custer Resource Center indicates the lack of water in the area eventually will limit the growth of the area. However, they predict that the population will grow approximately $20 \%$ over the next $10 \mathrm{yr}$.

Three population projections for Belfield are shown in Figure 4-1. The 0.68 constant annual growth rate is a continuation of the growth experienced by Belfield from 1960 to 1970 and represents the normal growth expected if the energy-related projects are not developed. Under this projection, using a base population of 1,650 people, the population would increase 168 to 1,920 people by the year 2005 . This pattern represents a conservative limit on the growth rate of Belfield.

The 2.38 declining annual growth rate is based on the projection by the Roosevelt-Custer Resource Center. This projection shows the growth rate declining linearly from its initial annual rate of $2.3 \%$ to zero growth after 25 yr. If this growth pattern were followed, the population would increase 208 over the first $10 \mathrm{yr}$ and reach a final population of 2,220 people by the year 2005, assuming an initial population 
of 1,650 people. This projection is considered the most likely of the three projections presented.

The 48 declining annual growth rate is a continuation of the estimated growth experienced by Belfield from 1970 to 1980 . Under this projection the growth rate declines linearly from its initial annual rate of $4 \%$ to zero growth after 25 yr. If this growth pattern were followed, the population would increase 388 over the next $10 \mathrm{yr}$ and reach a final population of 2,760 people by the year 2005, assuming an initial population of 1,650 people. This growth rate is considered as an optimistic limit on the growth rate of Belfield, considering the area's limited resources.

\subsection{LAND USE}

The site is presently being used as a maintenance and equipment storage area by the L.P. Anderson Construction Company. Land use around the Belfield site as determined by a field survey is depicted in Figure 4-2.

Most of the land near the site is used for grazing cattle and raising crops. There are several farmhouses within a $0.75-\mathrm{mi}$ radius of the site. Several oil and gas fields have been discovered around Belfield, and wells to produce these resources are scattered throughout the surrounding area.

The property just north of the main site is the yard of the Cenex company, an agricultural cooperative. The yard has a concrete building with a storage area, apparently used for maintenance and filling of LP-gas tanks.

The property just west of the site along the access road to the site is used by the state Highway Department as a maintenance and storage yard. The santa Fe Pipeline construction Company has a small mobile office located approximately $0.25 \mathrm{mi}$ west of the site. The nearest commercial activities are located over $1 \mathrm{mi}$ west of the site in Belfield city. The South Unit of the Theodore Roosevelt National Memorial Park is located approximately $6 \mathrm{mi}$ west of Belfield.

\subsection{IMPACT OF THE CONTAMINATED SOIL ON LAND VALUES}

Figure 4-3 summarizes the estimated 1980 market values of land around the Belfield site without improvements. Most of the land is privately owned.

The land on which the ashing plant was located is valued at approximately $\$ 10,000 / a c r e$. (The L.P. Anderson Construction Company leases 0.47 acres of the site, valued at approximately $\$ 4,500$.$) The rest of the industrial land along the railroad$ south of Belfield is valued at between $\$ 10,000$ and $\$ 15,000 /$ acre. 
The estimated market value of the agricultural land located around the site ranges from $\$ 150 /$ acre for grazing land to $\$ 400 / a c r e$ for cropland. The residential and commercial land within Belfield is valued from $\$ 2,000$ to $\$ 3,000 /$ acre. Commercial lands along U.S. Highway 85 between Interstate 94 and Belfield have estimated market values of between $\$ 10,000$ and

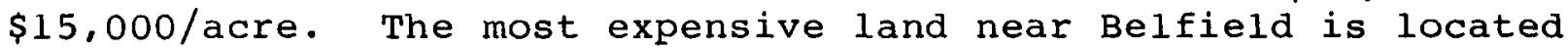
at the Intersection of Interstate 94 and U.S. Highway 85, where a 2 -acre tract recently sold for $\$ 50,000 / a c r e$.

The presence of the contamination at the Belfield site has very little influence on the use or the value of the site land or on the surrounding land. Presently, there are no pressures to develop the site for other than its present use, and it appears likely that no such pressures will develop in the future. 
ford, Bacon \& Đavis atab 3nc.

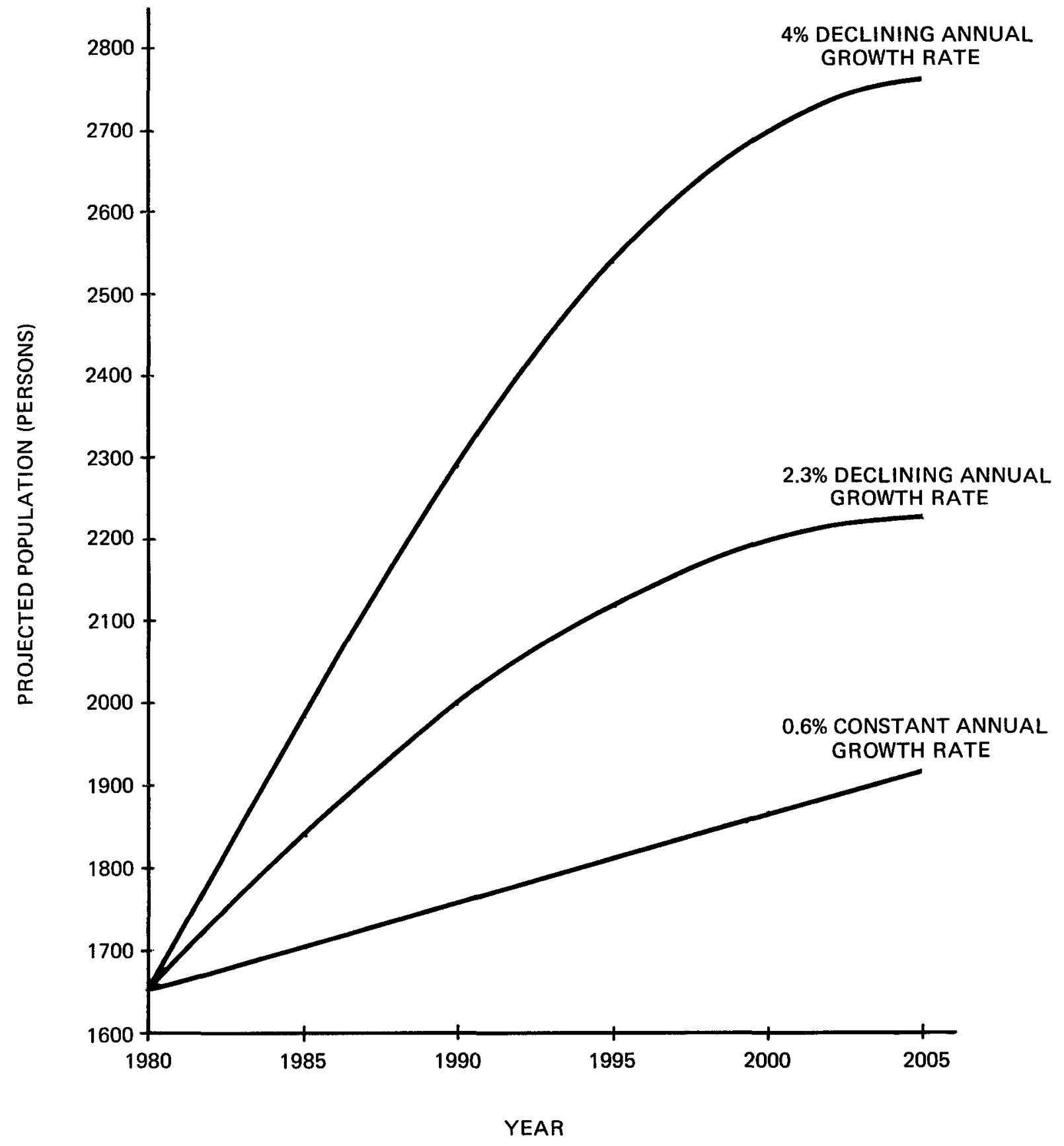

FIGURE 4-1. POPULATION PROJECTIONS 

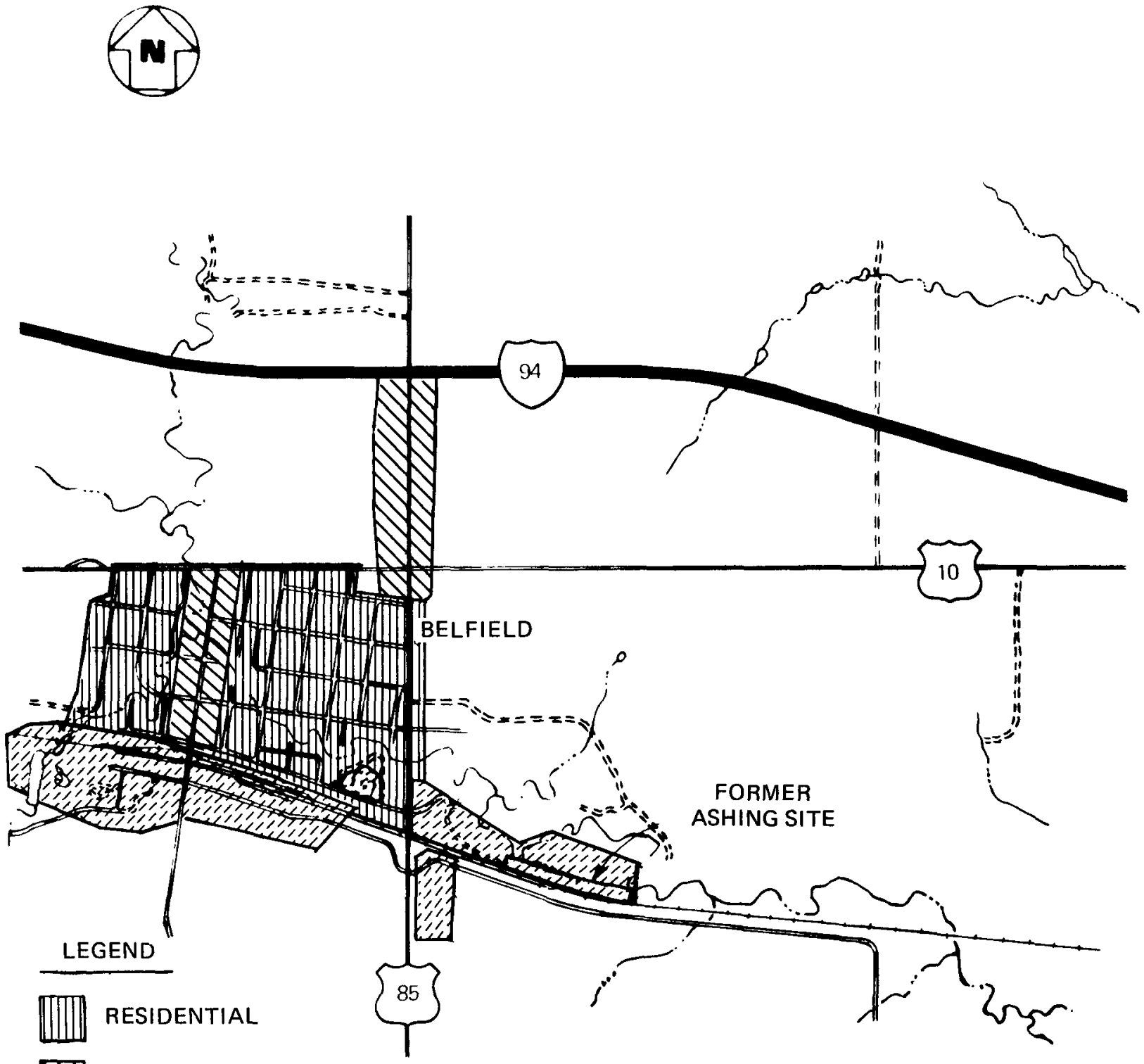

$\Delta$ COMMERCIAL

E: INDUSTRIAL

SREA RECREATION \& SERVICES

$\square$ VACANT-AGRICULTURE

$== \pm=$ DIRT ROAD

$\longrightarrow$ RAILROAD

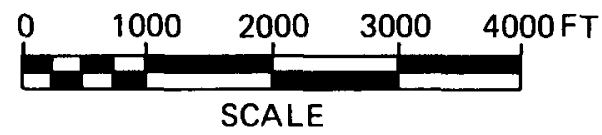

$\rightarrow x-x-$ FENCE

FIGURE 4-2. VICINITY LAND USE 

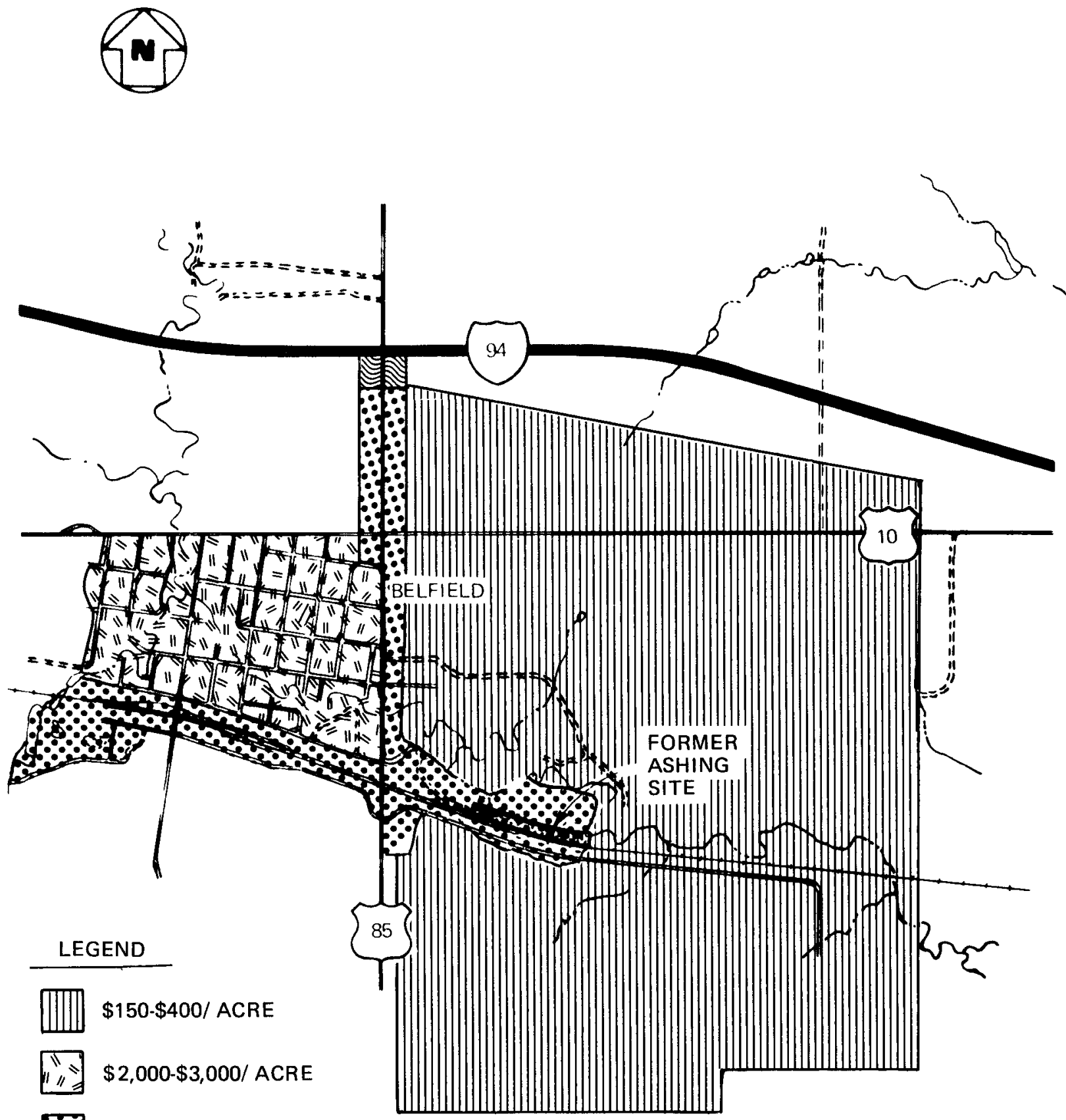

$\because \because 10,000-\$ 15,000 /$ ACRE

递 $\$ 20,000-\$ 50,000 / A C R E$

$\square$ OUTSIDE SURVEY BOUNDARY

+ RAILROAD

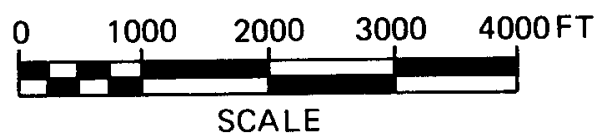

$==\mathbf{=}$ DIRT ROAD

FIGURE 4-3. MARKET VALUE OF LAND 


\section{TABLE 4-1}

POPULATION HISTORY OF BELFIELD AND STARK COUNTY

\begin{tabular}{|c|c|c|c|c|}
\hline & \multicolumn{2}{|c|}{ Belfield } & \multirow{2}{*}{$\frac{\text { Stark }}{\underline{\text { size }}}$} & County \\
\hline & Size & of Change & & z Change \\
\hline 1960 Census & 1,060 & -- & 18,451 & -- \\
\hline 1970 Census & 1,130 & 6.6 & 19,613 & 6.3 \\
\hline $\begin{array}{l}1980 \text { Census }(1) \\
\text { (preliminary figures) }\end{array}$ & 1,188 & 5.1 & 23,703 & 20.9 \\
\hline 1980 estimate $(2)$ & 1,650 & 46.0 & -- & -- \\
\hline
\end{tabular}


TABLE $4-2$

ESTIMATED 1980 POPULATION DISTRIBUTION

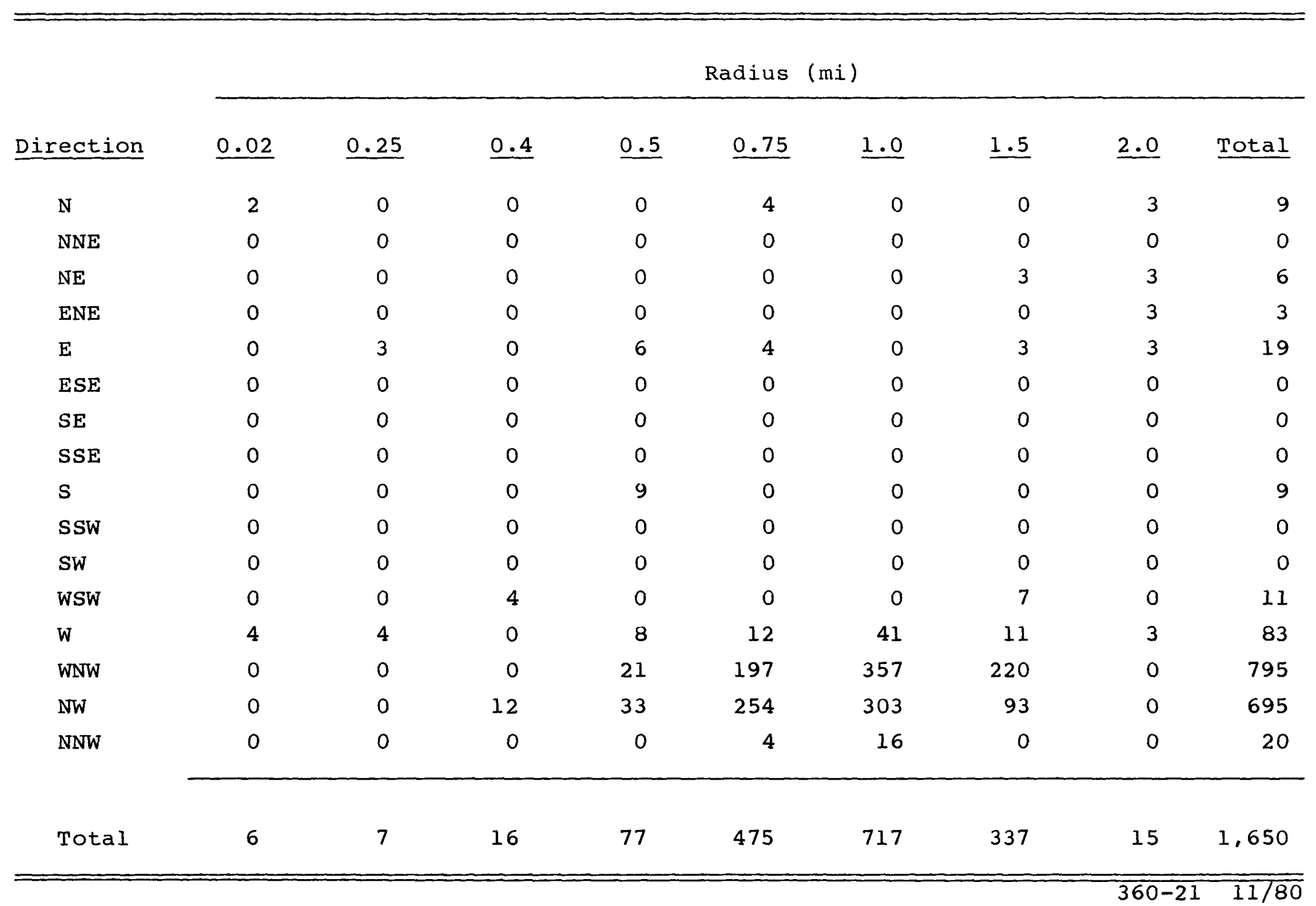


1. Deloris Mischel, Stark County Auditor; personal communication; Oct 28, 1980 .

2. Nita Ewoniuk, Belfield City Auditor's Office; personal communication; June 19, 1980. 
CHAPTER 5

RECOVERY OF RESIDUAL VALUES 


\section{RECOVERY OF RESIDUAL VALUES}

The ash generated at the Belfield site was the final product from the ashing operation. The ash was not processed at Belfield, but was shipped to Union Carbide's uranium ore processing plant in Rifle, Colorado, for processing. There is no tailings pile present at the Belfield site, and therefore there is no resource available for reprocessing. 
CHAPTER 6

STABILIZATION OF CONTAMINATED MATERIALS 
CHAPTER 6

\section{STABILIZATION OF CONTAMINATED MATERIALS}

In most of the alternative remedial actions that have been considered, stabilization of the radioactive contaminated waste materials left over from the processing of uranium-bearing ores is required. Among the types of waste materials are uranium mill tailings and ash. The inactive uranium mill tailings which are of concern in this study are located predominantly in the western United States. However, the site at Belfield, North Dakota, contains only ash waste left over from the processing of uranium-bearing lignite.

Government agencies and private industry have conducted and are conducting research to develop economical and environmentally suitable methods of stabilizing uranium mill tailings. The methods, technology, and data on stabilization that are presently available were reviewed and found to be applicable to the lignite ash. This information includes results from previous investigations, as well as findings of current and continuing research.

The objective of stabilizing the uranium mill tailings is to eliminate the pathways to the environment for the radioactive and other toxic particles which are described in chapter 3 . Alternatively, conditioning tailings might significantly reduce the rate at which potentially hazardous substances are released to the environment. Ideally, complete stabilization of radioactive tailings should permanently eliminate the possibilities of:

(a) Wind and water erosion

(b) Leaching of radioactive materials and other chemicals

(c) Radon exhalation from the tailings

(d) Gamma radiation emitted from the tailings

Implicit in these objectives is the additional goal of ensuring long-term stability and isolation of the tailings without the need for continued active maintenance. These objectives are consistent with those of the proposed EPA standards for inactive uranium mill tailings disposal.(1)

\subsection{PREVENTION OF WIND AND WATER EROSION}

Wind and water erosion could be prevented by treating the tailings surface (surface stabilization), solidifying the bulk of the tailings (volumetric stabilization), by emplacing covers 
over the tailings (physical stabilization), or by establishing plant growth over the tailings (vegetative stabilization). Each of these is discussed in the following paragraphs.

\subsubsection{Surface Stabilization}

Surface stabilization involves applying chemicals to the surface of the tailings to form a water- and wind-resistant crust. Surface stabilizers have been used successfully as a temporary protection on portions of dikes and tailings ponds which have dried and become dusty, and in areas where water shortage or chemical imbalance in the tailings prevents the use of cover vegetation. Surface stabilizers, however, are susceptible to physical breakup and gradual degradation and may not meet the long-term requirements for permanent stabilization of uranium mill tailings.

other complications also can arise in achieving satisfactory surface stabilization. For example, the surfaces of tailings piles seldom are homogeneous, and variables such as particle size, acidity, and moisture content affect the bonding characteristics and stability of the surface stabilizers.(2,3) studies are currently being conducted to assess the possibilities of conditioning uranium mill tailings to minimize their impact if they were to migrate to the biosphere.(4) It is possible that some conditioning techniques may change the characteristics of the tailings such that degradation of surface stabilizers by the tailings would be minimized.

Among the substances used to form crusts on mill tailings surfaces and thus reduce their susceptibility to wind erosion are: resinous adhesives; lignosulfonates; elastomeric polymers: milk of lime; mixtures of wax, tar, and pitch; potassium and sodium silicates; and neoprene emulsions.

Tests were conducted by the Bureau of Mines(2) using certain chemicals (e.g., Compound Sp-400 Soil Gard, and DCA-70 elastomeric polymers) on both acidic and alkaline uranium tailings. Subsequently, the chemicals DCA-70 and calcium lignosulfonate were applied to the surfaces of the inactive uranium tailings ponds and dikes at Tuba City, Arizona, in May 1968, because low moisture conditions and high costs prohibited vegetative or physical stabilization. After 4 yr, approximately $40 \%$ of the dike surface showed disruption while the crust in pond areas was affected to a lesser extent. The major disruptions were attributed to initial penetration of the stabilizer by physical means such as vehicles, people, or animals crossing the tailings surface.

In 1969, a portion of the Vitro tailings at Salt Lake City, Utah, was sprayed with tarlike material as a Bureau of Mines experiment $(5,6)$ to achieve surface stabilization and to reduce wind erosion. The material decomposed and exposed the tailings within 2 to 3 yr after application. 
"Cut-back" asphalt and asphalt-in-water emulsions also have been tested for use in protecting soils against wind and water erosion.(7) Both were shown to be effective for short periods of time when applied as a fine spray on sandy soils. on clay soils, the film disintegrated within a few weeks of application, apparently because of expansion and contraction of the clays during cycles of wetting and drying. The film was porous, allowed infiltration of water, and did not interfere with germination of wheat, grass, or legume seeds. The film is damaged by insects and rodents, and respraying may be necessary. Three to five years after application of the asphalt treatment, the amount of dry erodible surface area in the tested soils had increased, suggesting that asphalt treatments may not be desirable under all conditions.

More recent experiments performed for DOE are attempting to establish that surface stabilizers are useful in the long term. $(3,8,9,10,11)$ Although some asphaltic emulsions applied on tailings surfaces have degraded in less than $1 \mathrm{yr}$, covering the surface stabilizer with soil after application can extend its useful life. Nevertheless, additional data must be obtained to demonstrate long-term effectiveness of surface stabilizers.

Asphalt emulsions might be useful if mixed with a sufficient thickness of tailings or overburden material (admixing) to form a volumetric seal, as opposed to a thin coating on the tailings surface.(12) Admixing depths would have to be sufficient to minimize the potential for breakup of the volumetric seal. Recent studies have suggested that asphalt emulsion seals for uranium mill tailings may be stable for long-term applications.(11) Results of tests to determine the effects of temperature cycling (freeze-thaw), aqueous leaching, oxidation, exposure to brine solutions, and microbal attack indicate satisfactory stability of asphalt emulsions.

\subsubsection{Volumetric Stabilization}

Volumetric stabilization, which has been used in other mineral industry operations, involves the mixing of chemicals in sufficient quantities with tailings to produce a solidified, leach-resistant mass, much like mixing cement with sand and gravel to form concrete. The chemicals could be added in two ways: to a tailings slurry in a pipeline, or to the tailings in-situ. The in-situ method of stabilization is relatively new and research is being conducted to determine desirable materials to be added to tailings and the best techniques of application. (10,11)

One of the features claimed for this stabilization method is that all pollutant chemicals are locked in the solidified mass so they cannot be leached from the solid. Recent studies have indicated that volumetric stabilization may suffer from eventual degradation, and requires careful matching of 
environmental conditions, tailings, and solidifying chemicals in order to be effective.(9)

A cover material, such as soil, might be required to protect the solidified mass from wind and water erosion, depending on the substances added to the tailings. Shallow rooted vegetation can be established after soil cover has been placed over the solidified mass. However, the long-term effect of plant root penetration into the stabilized tailings is unknown but probably would be a function of the specific chemical makeup of the solidified mass. Continued research to identify the conditions under which vegetation could thrive without affecting the integrity of volumetric stabilizers is required.

\subsubsection{Physical Stabilization}

Physical stabilization consists of isolating the contained material from wind and water erosion by covering the tailings with some type of resistant material (e.g., rock, soil, smelter slag, broken concrete, asphalt, polymeric film, etc.).

Covers of gravel or crushed rock have been shown to be effective in preventing wind erosion and allow infiltration of water without permitting substantial erosion.(13) Riprap, a cover of substantial rocks, armors the surface against erosion and may enhance growth of vegetation.(14,15) clays or clayey soils would be self-healing if the tailings settled, would hold moisture, and could be a key component of a stabilizing cover.

Artificial covers, such as a layer of asphalt or a synthetic membrane, could be placed over the tailings to reduce wind and water erosion. However, synthetic membrane materials containing plasticizers, e.g., polyvinyl chloride (PVC), are not suitable for exposed surface application because they are susceptible to damage by ultraviolet radiation. However, a thin synthetic sheet, although protected by soil from direct exposure, would have questionable mechanical strength and might not be able to maintain integrity in the long term.

In some arid regions, where the potential for successful vegetative stabilization is slight, physical stabilization may be the preferred alternative. In such areas, combinations of pit-run sand and gravel, soil, and riprap have been placed over the tailings and have been successful in preventing wind and water erosion.

An important component of physical stabilization is the proper treatment of the finisned surface by such means as contour-grading and terracing. Broad range surface runoff control channels and grading are also imperative to assure that the tailings site is protected from erosion by rainstorms 
and floods. Such treatments can greatly reduce long-term maintenance requirements and costs.

Both root growth and animal burrowing may provide pathways from the stabilized tailings to the environment and are therefore of concern. Research is currently under way to evaluate various chemical biobarriers for uranium mill tailings.(11) Herbicides in the form of polymeric sheets and pellets are being tested to determine their long-term ability to prohibit root growth into the tailings through the stabilizing cover material. Apparently, polymeric sheets containing herbicide are more costly than pellets, and pellets are substantially more convenient to use.

Burrowing habits of rodents and potential methods to limit burrowing are being investigated. It is believed that mechanical barriers will be more effective and less costly than chemical barriers in excluding burrowing animals from disposed tailings.

\subsubsection{Vegetative Stabilization}

Vegetative stabilization involves the establishment of plant growth on the tailings or on a growing medium placed over the tailings on the premise that the root system will tend to hold the soil in place.

will: (11)

Criteria for plant selection provide that the plants

(a) Be tolerant of local environmental conditions.

(b) Have properties that will aid in erosion control.

(c) Have propagules that are readily available.

(d) Be relatively easy to establish.

(e) Be perennials, or annuals with good reproductive capabilities.

(f) Have minimal rooting depth requirements.

(g) Be of low food value and/or palatability.

(h) Have low value as habitat for wildlife.

Many species of plants require little or no maintenance after growth becomes established, an essential aspect of vegetative stabilization. Vegetation may be able to survive provided that: 
(a) Evapotranspiration is not excessive.

(b) Landscapes are properly shaped.

(c) Nontoxic soil media capable of holding moisture are provided.

(d) Irrigation and fertilization appropriate to the area are applied to initiate growth.

Growth of vegetation at sites receiving less than 10 in. of annual precipitation and with high evapotranspiration rates requires initial irrigation and fertilization. At Belfield. precipitation averages about 16 in. annually.

A principal disadvantage of vegetative stabilization is the possibility of uptake of radioactive elements by the plants. However, if the plants are properly selected, and if there is a sufficient depth of soil cover over the tailings, this uptake will be minimal. Barriers to root penetration are currently being evaluated.

\subsection{PREVENTION OF LEACHING}

Leaching into underground aquifers is one of the pathways that chemicals and radioactive materials might follow to the environment. The techniques that could be employed to control leaching from tailings piles include the following:

(a) Employ surface, volumetric, or physical stabilization to minimize infiltration of water, which would prevent leaching of hazardous elements into underground aquifers.

(b) Physically compact the tailings to reduce the percolation of water through the materials.

(c) Contour the drainage area and tailings surface to minimize the potential for water to penetrate into the tailings.

(d) For a new site, line the disposal area with a low-permeability membrane.

(e) Condition tailings to reduce leachability or contaminant content.

Current research of various liner systems has identified eight liner naterials for continued laboratory study: 
(a) Natural soil amended with sodium-saturated montmorillonite (Volclay*)

(b) Typical local clay with an asphalt emulsion radon-suppression cover

(c) Typical local clay with a multibarrier radonsuppression cover

(d) Rubberized asphalt membrane

(e) Hydraulic asphalt concrete

(f) Chlorosulfonated polyethylene (Hypalon*) or high-density polyethylene

(g) Bentonite, sand and gravel mixture

(h) Catalytic airblown asphalt membrane

Of these materials, the rubberized and hydraulic asphalts are judged to be the two most viable candidates at this time.(11)

Other studies(4) are addressing the possibility of conditioning the tailings such that if they were to leach, there would be minimal adverse impact.

\subsection{REDUCTION OF RADON EXHALATION}

Continuing research is directed toward reduction of radon exhalation from tailings piles. $(3,8,9,16,17)$ while there are materials that can seal or contain the gas on a laboratory scale, their use for permanent coverage of large areas is presently being studied.

From simplified diffusion theory estimates, it can be shown that about $13 \mathrm{ft}$ of $\mathrm{dry}$ soil $(18,19)$ are needed to reduce radon flux by 958 , but only a few feet of soil are needed if a high moisture content in the cover material is maintained. Figure 6-1 depicts the dependence on moisture content of the effective diffusion coefficient for radon in soil. The dramatic decrease of the magnitude of the effective diffusion coefficient as the moisture content increases is responsible for the resulting reduction of radon flux. (20)

The reduction of radon exhalation flux for three soil types versus depth of cover is presented in Figure 6-2 and is based upon the theory and diffusion coefficients presented in the

\footnotetext{
*Registered trademark.
} 
references cited earlier. Further research is currently under way to explore more precisely the problems associated with reducing and eliminating the exhalation of radon from radioactive tailings material. The effects of applying various surface stabilizers and varying thicknesses of stabilizing earth covers and combinations of materials are being investigated. The results may have an important impact in planning radon exhalation control. However, proposed NRC standards for stabilizing inactive mill tailings require a minimum of $3 \mathrm{~m}$ of cover over the tailings.(1) The $3-m$ cover was assumed to be sufficient to meet proposed radon release requirements in remedial action cost estimates presented in this report.

Investigations described in Paragraph 6.1 have shown that cationic asphalt emulsions can be effective in large-scale applications in reducing radon fluxes to required levels.(11)

Studies of multilayer physical stabilization systems presently in progress are directed at identifying cost effective cover systems to satisfy proposed EPA standards for disposal.(1) These studies have indicated that, under a given set of conditions, a single-material cover would have to be up to about $24 \mathrm{ft}(7.2 \mathrm{~m})$ thick to reduce radon flux to the required $2 \mathrm{pCi} / \mathrm{m}^{2}-\mathrm{s}$. In contrast, a well designed multilayer cover system of less than $8.5 \mathrm{ft}(2.6 \mathrm{~m})$ thickness under the same conditions could satisfy the radon flux requirement.

\subsection{REDUCTION OF GAMMA RADIATION}

A few feet of cover material are sufficient to reduce gamma radiation to background levels.

The reduction of gamma exposure rates resulting from a packed earth covering is given in Figure 6-3. $(8,21)$ Two feet of cover reduce the gamma levels by about two orders of magnitude. Therefore, an average cover thickness of $3 \mathrm{~m}$ should reduce gamma levels from the tailings to background. Multilayer and asphalt cover systems currently under investigation have been shown to effectively attenuate gamma levels to acceptable ranges.

\subsection{ASSESSMENT OF APPLICABILITY}

Available data indicate that the methods previously used at the inactive sites in attempts to stabilize uranium tailings have not been totally satisfactory and that long-term solutions to uranium tailings site radiation problems have yet to be clearly demonstrated. Consequently, new or combination methods of stabilization are being evaluated. The present remedial action options include physical stabilization of the tailings with at least $3 \mathrm{~m}$ of well designed soil cover and $0.3 \mathrm{~m}$ of riprap. This action will reduce gamma radiation and wind and water erosion, substantially reduce radon exhalation, minimize infiltration, and allow reestablishment of native vegetation. 
If remedial actions are taken, combinations of the methods described in this chapter for preventing erosion, leaching to ground water, radon exhalation, and gamma radiation will be implemented based on climatic, hydrogeological, economic, and demographic factors. The method of stabilizing uranium mill tailings whereby $3 \mathrm{~m}$ of well-engineered cover is placed on the pile is apparently the primary method currently available that satisfies both U.S. (1) and Canadian(22) regulatory requirements. 


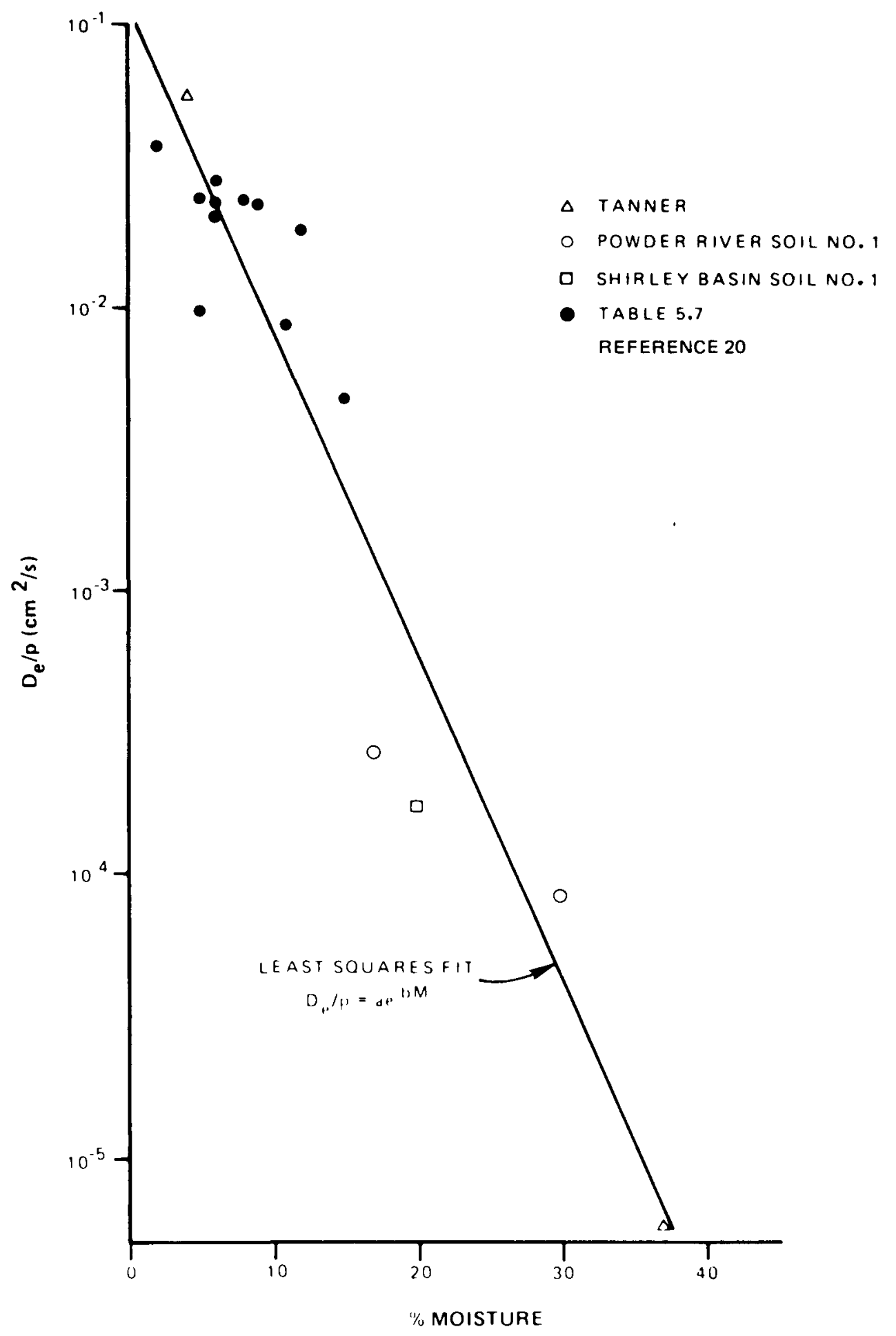

FIGURE 6-1. EXPONENTIAL MOISTURE DEPENDENCE OF THE DIFFUSION COEFFICIENT 
ford. Bacon \& Darts Mab _mic.

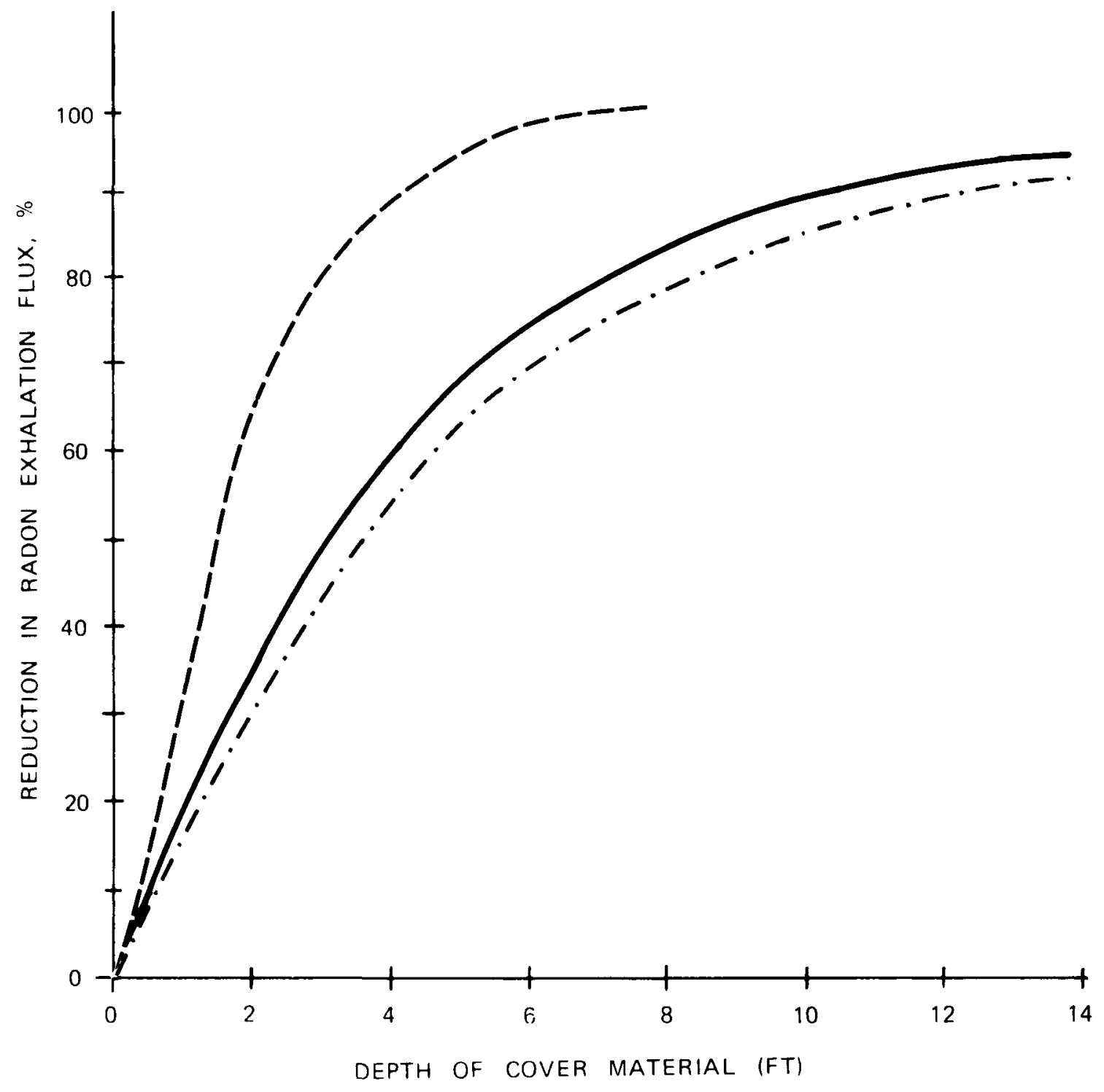

LEGEND

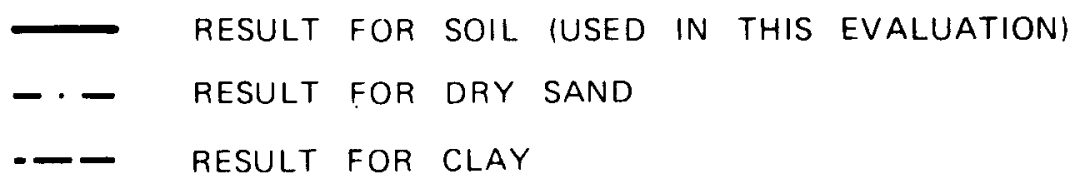

FIGURE 6-2. REDUCTION OF RADON EXHALATION FLUX WITH DEPTH OF COVER

$360-21 \quad 11 / 80$

$6-11$ 


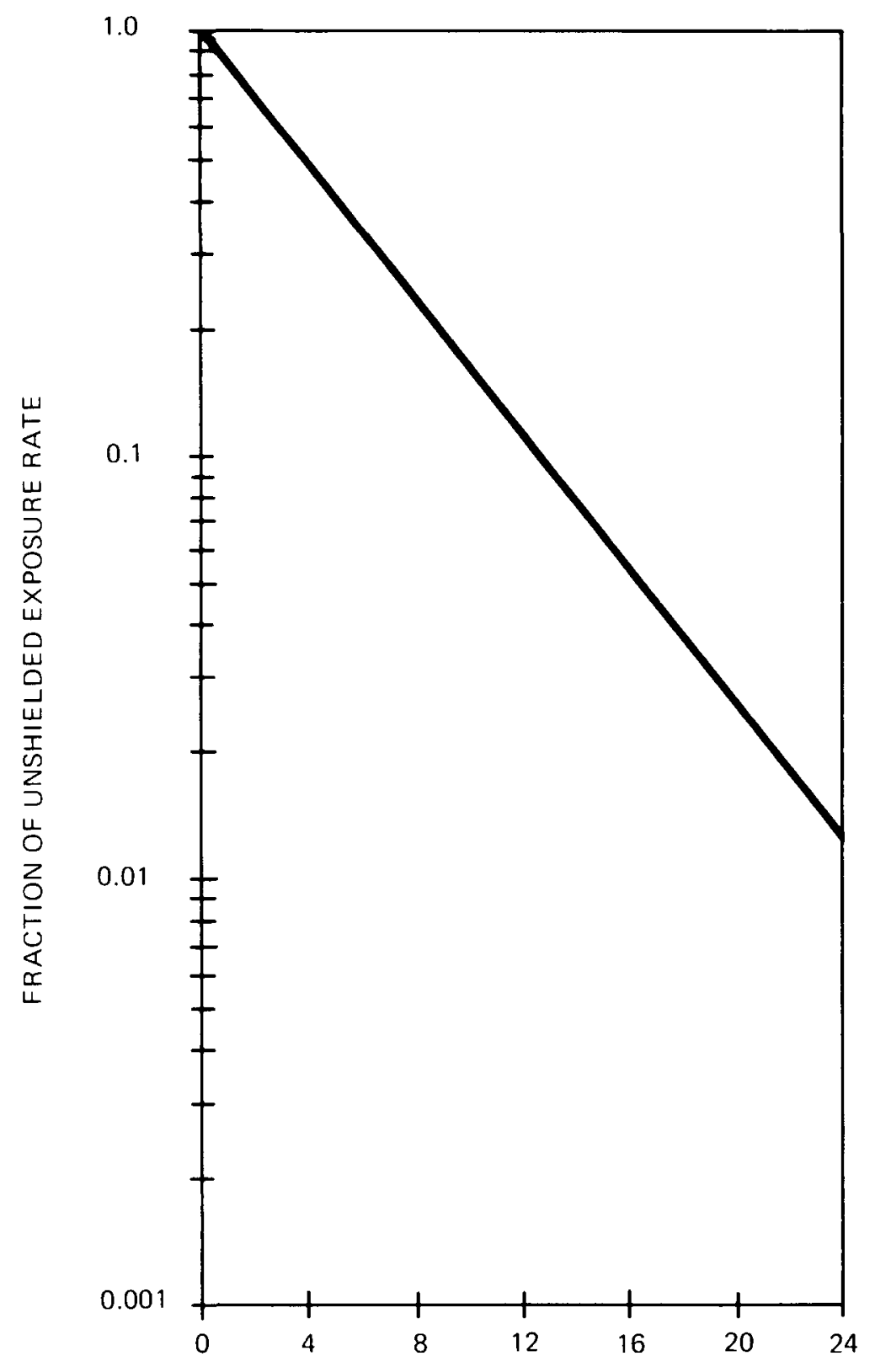

DEPTH OF OVERBURDEN (IN.)

FIGURE 6-3. REDUCTION OF GAMMA EXPOSURE RATE RESULTING FROM PACKED EARTH SHIELDING 


\section{CHAPTER 6 REFERENCES}

1. "Proposed Disposal Standards for Inactive Uranium Processing Sites, Invitation for Comment"; U.S. Environmental Protection Agency; Federal Register; Vol 46, No. 6 ; p. 2556; Jan 9, 1981 .

2. "Methods and Costs for Stabilizing Fine sized Mineral Wastes"; Bureau of Mines Report of Investigation; RI7896; 1974 .

3. P.L. Koehmstedt, J.N. Hartley, and D.K. Davis; "Use of Asphalt Emulsion Sealants to Contain Radon and Radium in Uranium Tailings"; BNWL-2190; Battelle Pacific Northwest Laboratories; Richland, Washington; Jan 1978.

4. D.R. Dreesen and J.M. Williams; "Monthly Report, November 1980"; Los Alamos Scientific Laboratory, Environmental Science Group.

5. R. Havens and K.C. Dean; "Chemical Stabilization of the Uranium Tailings at Tuba City, Arizona"; U.S. Department of the Interior, Bureau of Mines; 1969.

6. K.C. Dean, et al.; "Progress in Using and Stabilizing Mineral Wastes"; Salt Lake Metallurgical Research Center; 1970 .

7. W.S. Chepil; "Effects of Asphalt on Some Phases of Soil Structure and Erodibility by Wind"; Soil Science Society of America Proceedings 19:125-128; 1955 .

8. P.J. Macbeth, et al.; "Laboratory Research on Tailings Stabilization Methods and Their Effectiveness in Radiation Containment"; GJT-21; Ford, Bacon \& Davis Utah Inc.; Salt Lake City, Utah; Apr 1978.

9. B.J. Thamer, et al.; "Radon Diffusion and Cover Material Effectiveness for Uranium Tailings Stabilization"; FBDU258; Ford, Bacon \& Davis Utah Inc; Salt Lake City, Utah; May 1980 .

10. J.N. Hartley, P.L. Koehmstedt, and D.J. Esterl; "Asphalt Emulsion Sealing of Uranium Mill Tailings"; Battelle Pacific Northwest Laboratories; Richland, Washington; 1979 .

11. T.D. Chikalla, Compiler; "Quarterly Uranium Tailings Report, October through December 1980"; Pacific Northwest Laboratory; Feb 1981. 
12. J.N. Hartley, et al.; "Uranium Mill Tailings Stabilization"; Feb 1980; presented at Waste Management 80; Tucson, Arizona; Mar 10-14, 1980.

13. W.S. Chepil, N.P. Woodruff, F.H. Siddoway, D.W. Fryrear, and D.V. Armburst; "Vegetative and Nonvegetative Materials to Control Wind and Water Erosion"; Soil Science Society of America Proceedings 27:86-89; 1963.

14. J.D. Nelson and T.A. Shepherd; "Evaluation of Long-Term Stability of Uranium Tailing Disposal Alternatives"; Civil Engineering Department, Colorado state University, Fort Collins, Colorado; prepared for Argonne National Laboratory; Apr 1978.

15. D.R. Dreesen, M.L. Marple, and N.E. Kelley; "Containment, Transport, Revegetation, and Trace Element studies at Inactive Uranium Mill Tailings Piles"; Proceedings of Symposium on Uranium Mill Tailings Management, Colorado State University, Fort Collins, Colorado; Nov 20-21, 1978.

16. G.W. Gee, et al.; "Interaction of Uranium Mill Tailings Leachate with Soils and Clay Liners"; NUREG/CR-1494; Battelle Pacific Northwest Laboratories, Richland, Washington; May 1980 .

17. P.J. Macbeth, et al.; "Research on Radon Gas Diffusion and Attenuation from Uranium Mill Tailings"; Paper Presented at International Conference on Uranium Mine and Mill Tailings Disposal; Vancouver, B.C., Canada; May 19-21, 1980.

18. A.B. Tanner; "Radon Migration in the Ground: A Review"; The Natural Radiation Environment; J.A.S. Adams and W.M. Lowder, eds; University of Chicago Press; pp. 161-190; 1964 .

19. H.W. Kraner, G.L. Schroeder, and R.D. Evans; "Measurements of the Effects of Atmospheric Variables on Radon-222 Flux and Soil-Gas Concentrations"; The Natural Radiation Environment; J.A.S. Adams and W.vi. Lowder, eds; University of Chicago Press; 1964.

20. V.C. Rogers, et al.; "Characterization of Uranium Tailings Cover Materials for Radon Flux Reduction"; NUREG/CR-1081 and FBDU-218-2; Jan 1980.

21. K.J. Schiager; "Analysis of Radiation Exposures on or Near Uranium Mill Tailings Piles"; Radiation Data and Reports; Vol 15; July 1974 .

22. K.E. Hanney, et a1.; "Reclamation Concepts and Practice for Uranium Tailings Impoundments"; Paper Presented at International Conference on Uranium Mill Tailings Disposal; Vancouver, B.C., Canada; May 19-21, 1980. 


\section{CHAPTER 7}

OFF-SITE REMEDIAL ACTION 


\section{CHAPTER 7 \\ OFF-SITE REMEDIAL ACTION}

For the purposes of this report, locations where radioactive residues have been transported off site by individuals or by wind are considered as off-site properties. Locations within the established $5-\mathrm{pCi} / \mathrm{g}$ boundary are considered as windblown areas. Contaminated areas within the official site boundaries, e.g., ash residues, millsite, and windblown contamination of open areas, are not considered as off-site contaminated properties.

The identification of locations and land areas off site where the contaminated ash or lignite may have been transported and used by individuals was not included in the scope of this project and was not attempted. The ash was the valued final product of the lignite-ashing operation at Belfield and was transported by covered railcar to Rifle, Colorado, for further processing. Therefore, for the purposes of this report, it is assumed that no ash was used off site at Belfield.

\subsection{DATA SOURCES}

The gamma survey and $226_{\mathrm{Ra}} 5-\mathrm{pCi} / \mathrm{g}$ boundary mentioned in Paragraph 3.5 were the data sources for the consideration of remedial action for windblown areas.

\subsection{REMEDIAL ACTION FOR OFF-SITE PROPERTIES OTHER THAN \\ WINDBLOWN}

Since no off-site properties were identified where contaminated ash was located, there is no cost associated with off-site remedial action. However, any off-site contaminated properties that might be located in the future would probably require appropriate remedial action and would be included in any remedial action program, provided their levels of contamination exceeded prevailing standards.

\subsection{REMEDIAL ACTION FOR OFF-SITE WINDBLOWN PROPERTIES}

The extent of windblown contamination is indicated by the 5-pCi/g line in Figure 3-5. Decontamination of those areas containing windblown contamination would involve removing the contaminated soil and replacing it with clean fill. The result of this action is assumed to satisfy remedial action criteria as mentioned in Paragraph 3.5.

Remedial action for any part of the 8-acre Belfield site was considered in cost estimates for the site, as discussed in Chapter 9. Therefore, cleanup costs for the site itself are not included under remedial action for windblown areas. 
The estimated 5-pci/g line extends to include one structure (the Cenex Company office building) that is adjacent to the site on the north. For the purpose of cost estimating, it was assumed that remedial action for this building would be necessary. Cleanup and restoration costs for this structure and approximately 21 acres of land contaminated by windblown ash in the vicinity of the site are estimated to be $\$ 300,000$, exclusive of allowances for engineering design and contingency.

All off-site areas would be decontaminated by removing an average of 6 in. of soil, gravel, roads, etc., to the base of the site. After decontamination, the affected areas would be restored with uncontaminated material. 


\section{CHAPTER 8}

DISPOSAL SITE SELECTION 


\section{CHAPTER 8}

\section{DISPOSAL SITE SELECTION}

Several of the remedial action options considered in this engineering assessment would involve moving the contaminated material at the Belfield site to a disposal site. Potential disposal sites were located based on NRC regulations. With the presently proposed regulations requiring at least $3 \mathrm{~m}$ of cover material for the disposal of uranium mill tailings (ash) from uranium processing plants, potential sources for these large amounts of cover materials have been located for each of the presently viable disposal options. The relative locations of actual sources of cover material to the various disposal sites will impact the costs.

\subsection{CRITERIA FOR DISPOSAL}

Local agencies, concerned individuals, and personnel in industry were contacted to locate possible disposal sites for the contaminated materials at the Belfield site. In addition, other sites that could meet the federal and state criteria for disposal sites were sought and identified. In general, consideration was limited to off-site disposal at local mines and pits. Increased attention was given to those mines which originally contained the uranium-bearing lignite. Local scoria pits also appear well suited for disposal purposes.

In all, 12 disposal sites were considered and a reconnaissance survey was made of each site. Of these, three sites were selected for cost estimate studies and included as options. These locations are considered in options II through IV. Table 8-1 gives the name of each disposal site studied and the road distance of each from the Belfield site. Figure 8-1 shows the relative locations of the proposed disposal sites.

While 12 sites were actually visited, only the three selected for options are discussed in depth. The others were eliminated for various reasons, including proximity to the water table, longer haul distances when closer sites were available, size and configuration of the pit, surface drainage problems, and excessive erosion in the Badlands area.

Special consideration was given to disposal of the contaminated material in the numerous uranium and scoria pits in the area. Since there is a relatively small amount (approximately $56,600 \mathrm{yd}^{3}$ ) of contaminated material at and around the site, disposal of the contamination at any of these pits could be easily accommodated. 
Lach site forming the basis for an option was evaluated to a limited extent as to hydrology, meteorology, ecology, and economics. The disposal site evaluations consisted of literature surveys and limited on-site inspections. The hydrologic and meteorologic conditions were assessed with regard to such factors as wind and water erosion, water contamination, flooding and drainage characteristics, precipitation, exposure to sun and wind, soil type and depth to bedrock, and location of confined aquifers. Special consideration was given to drainage basin configuration, subsurface and surface drainage, and natural disposal basin features. The geologic examination addressed stability problems and soil characteristics, such as evidence of slides or faults and types of unconsolidated and bedrock materials. The ecological study evaluated land use potential, animal habitats, proximity to population centers, and aesthetic considerations. Economic considerations included preliminary estimates of support facilities such as highways, railroads, distance from the Belfield site, and the extent of disposal site preparation and long-term maintenance required at the disposal site.

\subsection{DESCRIPTIONS OF DISPOSAL SITES CONSIDERED AS OPTIONS}

All of the sites considered (except disposal on the current Belfiela site) are in pits that intersect the sentinel Butte Formation. Since this formation contains an aquifer in the area, a drilling program would be necessary to determine the types and depths of soils underlying each pit. If there were no clays underlying the site, which could prevent percolation, consideration should be given to lining the pit with clays before emplacing the contaminated soils. This would provide additional protection against percolation, which already would be minimized by selection of a site with minimal or no upstream drainage. All of the disposal sites have been previously disturbed and would be minimally affected in terms of aesthetics; in fact, they might be improved by the restoration that would accompany the ash disposal.

The badlands area around Belfield was briefly considered for ash disposal but was eliminated from further investigation because of excessive erosion conditions.

All of the disposal sites (pits) considered as options are located within $17 \mathrm{mi}$ of the Belfield site and are accessible by using a combination of paved and gravel roads. The existing roads to each pit are adequate for the heavy haul loads that would be required.

The deposit procedure, if necessary, would involve lining the pit with a clay or synthetic liner; depositing the contaminated soil and material from the present ash site; and covering the contaminated soil with $3 \mathrm{~m}$ of cover material which must be hauled to the disposal pit from surrounding areas such as the 
badlands. The relocated and stabilized material would have gently angled slopes and be contour-graded to minimize water erosion.

For cover material at the disposal site, $3 \mathrm{~m}$ of lowpermeability soils and $0.3 \mathrm{~m}$ of gravel or cap material will be required. Gravels are scarce in North Dakota, southwest of the Missouri River, and are found in scattered deposits in terraces and along modern streams. The gravels that are found tend to contain a large percentage of fines and high chert and shale pebble fractions. Consequently, the gravels often must be washed and do not meet concrete aggregate specifications prescribed by many government agencies. They would be adequate as a gravel cap material, however. The closest of these deposits was located north of Dickinson, where there are several commercial pits. This would require a haul distance of about $25 \mathrm{mi}$.

For many local roads, scoria and/or sandstone are mined and crushed. This would be a more available local source for the cap material. Sandstones are exposed in many of the local lignite mines, and scoria pits are scattered throughout the area. While these materials are not especially suitable for surfacing roads, they probably are durable enough to use as a cap for protection against erosion by wind or surface runoff. In general, it would not be necessary to crush the scoria, and pit-run scoria could serve as a cap for the pile.

There are numerous scoria pits within a 4-mi radius of the present Belfield site which have provided material for local roads. Several of these pits were examined during the field work. One pit is $3.8 \mathrm{mi}$ east of Belfield on the frontage road adjacent to Interstate Highway 94. There is a large stockpile of crushed scoria at the pit which can be seen from the highway. This pit is leased by Fisher sand and Gravel from a private landowner.

Most of the surrounding countryside consists of loamy to clayey soils. If additional clay cover were necessary, there might be difficulty in obtaining soils from cropland; however, there are areas used largely for grazing where it might be easier to obtain cover material. There are also several areas where commercial-grade clays are obtainable. Kaolinitic clays obtained from the Golden Valley Formation in the Dickinson area have been utilized commercially.

Also, montmorillonitic clays occur in southwest North Dakota. They are found in many of the formations in the area; those in the white River Formation are used commercially. The plant that was operated on the Belfield site in 1971 used nonswelling bentonite clays from this formation to manufacture floor absorbent and cat litter. The clays were obtained in the southwest corner of Township 138 North, Range 98 West, southeast of Belfield. Both of these areas could provide very 
tight clays for cover, but would require haul distances of 17 to $25 \mathrm{mi}$. Acquisition of these lands would be easier, however, since they have been previously mined for clays. Also, the Little Badlands area is low-value wasteland that is unsuitable for farming.

Transportation, site preparation, and maintenance costs are discussed more fully in Chapter 9.

$\frac{\text { 8.2.1 Uranium Pit in Township } 140 \text { North, Range } 99 \text { West, }}{\text { Section } 6-- \text { Site } 3 \text { (Option II) }}$

This disposal site is located north of the site in Section 6 of Township 140 North, Range 99 West. This is an old uranium pit on private land, (1) approximately 8 road miles from the Belfield site. It is comparatively isolated with scattered ranch houses in the area. There are two farm houses within $1 \mathrm{mi}$ of this pit. It is located on a knoll that is isolated from upstream drainage.

It would be desirable to line at least the sides of the pit with a clay or synthetic liner since the sides are sandstone. If excavation were necessary to accommodate the contaminated soil and cover, the excavated material could be used for part of the cover. There are abundant fine-grained soils in the vicinity that could be used for cover. In fact, much of the grazing land just west of the site owned by the U.S. Forest service has clay loam soils. Also, if clays were shipped from one of the commercial grade sources, the distance would be between 10 and $30 \mathrm{mi}$, not much farther than to the present Belfield site.

For the cap material, either the nearest scoria pits or the commercial gravels from Dickinson could be used. This would require a haul of from 2 to $5 \mathrm{mi}$ for the scoria, or about $30 \mathrm{mi}$ for the gravel.

Access to the site is north along Highway 85 for $6 \mathrm{mi}$, then west for $2 \mathrm{mi}$ to the pit.

\subsubsection{Scoria Pits in Township 139 North, Range 99 West, Section 1-- Site 7 (Option III)}

This disposal site is the commercial scoria pit area on Highway 16, just east of the site. The site is in section 1 of Township 139 North, Range 99 West, about 4.8 road miles from the site, in a comparatively isolated area. There are ranch houses in the area and about five farm houses within $1 \mathrm{mi}$ of the pits. The pits are well isolated from upstream drainage.

There are two pits at this location now, one of which appears to be actively mined. It might be necessary to excavate between the pits to form one large pit. Some consideration also might be given to the loss of the scoria as a resource. 
It probably would be necessary to line at least the sides of this pit with clays or a synthetic liner since the scoria is very fractured. The scoria from the pit could be used for the cap, or the gravels could be trucked in from Dickinson.

Clay cover could be obtained from the local soils or from the commercial-grade clays, as it could also for the Belfield site. Haul distances for the commercial-grade clays would be about 15 to $20 \mathrm{mi}$.

Access to the site is north along U.S. Highway 85 to U.S. Highway 10, then east along U.S. Highway 10 for $4.5 \mathrm{mi}$. The pits are located on the south side of U.S. Highway 10.

8.2.3 Uranium Pit in Township 137 North, Range 100 West, Section 2 - Site 8 (Option IV)

This site is southwest of Belfield in section 2 of Township 137 North, Range 100 west, about 17 road miles from the site, in a comparatively isolated area. There are farm houses scattered throughout the area, but there is only one house within $1 \mathrm{mi}$ of the pit.

The site is an old uranium pit with little upstream drainage. It probably would be desirable to line at least the sides of the pits with a clay or synthetic liner. clay cover could be obtained from the local soils or from the commercial clays in the Badlands area. A haul distance of $15 \mathrm{mi}$ would be necessary to obtain clays from the Little Badlands area. The cap material could be obtained from local scoria pits. Gravels might best be obtained from deposits in sections 21 and 27 of Township 137 North, Range 97 West, 19 to 23 road miles from the disposal site, which is closer than the Dickinson deposits.

Access to this site is south along U.S. Highway 85 for $12.5 \mathrm{mi}$, then west for $4 \mathrm{mi}$ to the pit. 
ford, Bacon \& Davis łtab 3nc.

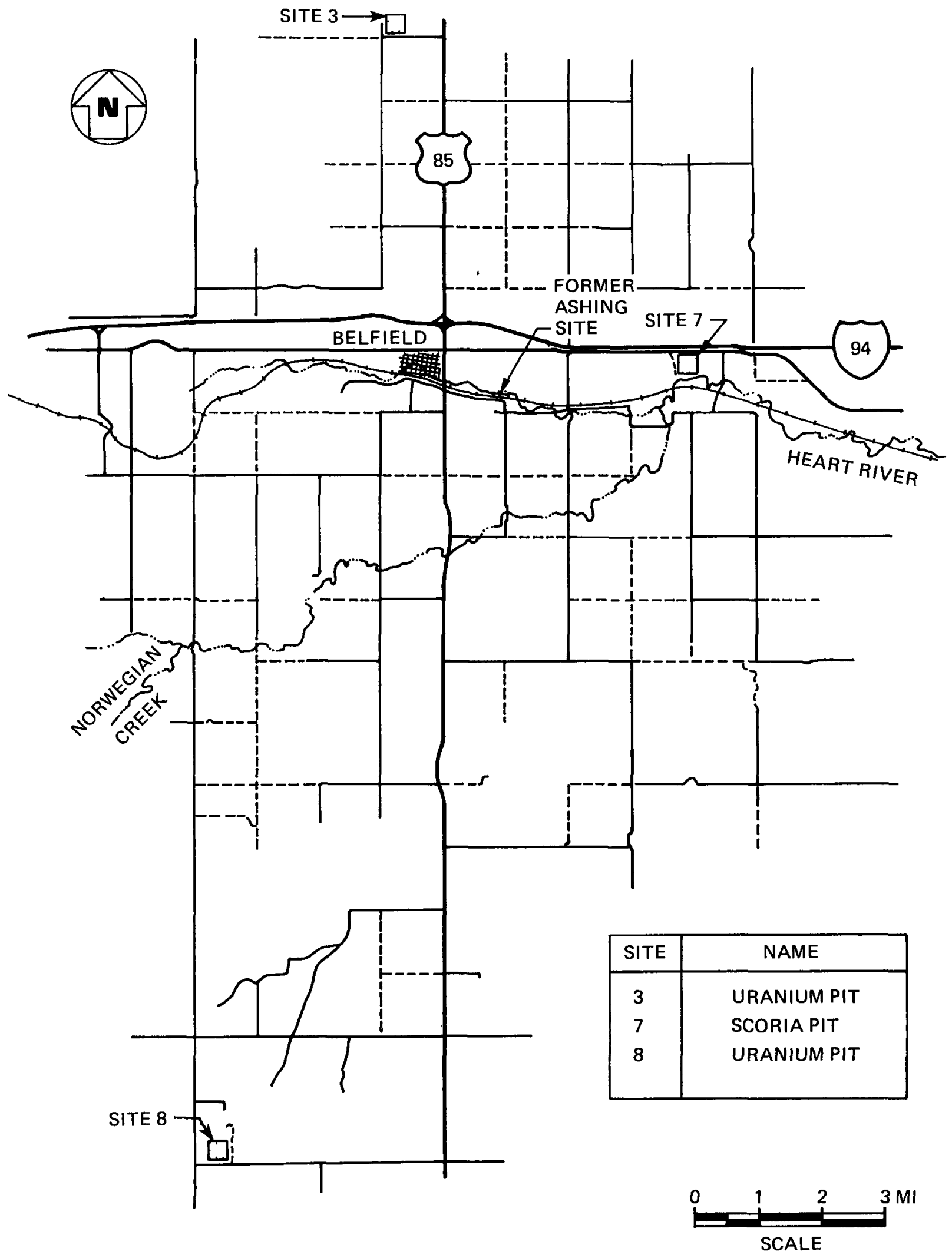

FIGURE 8-1. LOCATION OF PROPOSED DISPOSAL SITES 


\section{TABLE 8-1}

SITES EVALUATED FOR DISPOSAL OF THE CONTAMINATED MATERIALS FROM THE FORMER BELFIELD LIGNITE-ASHING PLANT

\begin{tabular}{|c|c|c|c|}
\hline $\begin{array}{l}\text { Site } \\
\text { No. }\end{array}$ & $\begin{array}{l}\text { Option } \\
\text { No. } \\
\end{array}$ & $\begin{array}{c}\text { Road Miles } \\
\text { from } \\
\text { Ash Area } \\
\end{array}$ & Site Description \\
\hline 1 & -- & 16 & $\begin{array}{l}\text { Uranium Pit in } \mathrm{T} 142 \mathrm{~N}, \mathrm{R} 99 \mathrm{~W}, \\
\text { Sec } 1\end{array}$ \\
\hline 2 & -- & 25 & $\begin{array}{l}\text { Uranium Pit in } \mathrm{T} 142 \mathrm{~N}, \mathrm{R} 100 \mathrm{~W} \\
\text { Sec } 10\end{array}$ \\
\hline 3 & II & 8 & $\begin{array}{l}\text { Uranium Pit in } T 140 \mathrm{~N}, \mathrm{R} 100 \mathrm{~W} \text {, } \\
\text { Sec } 6\end{array}$ \\
\hline 4 & -- & 7.5 & $\begin{array}{l}\text { Large Pit in T } 140 \mathrm{~N}, \mathrm{R} 99 \mathrm{~W} \text {, } \\
\text { Sec } 7\end{array}$ \\
\hline 5 & -- & 3.5 & Mine in T $140 \mathrm{~N}, \mathrm{R} 99 \mathrm{~W}$, Sec 28 \\
\hline 6 & -- & 3.5 & Mine in T $140 \mathrm{~N}, \mathrm{R} 99 \mathrm{~W}$, Sec 27 \\
\hline 7 & I I I & 4.8 & $\begin{array}{l}\text { Scoria pit in } \mathrm{T} 139 \mathrm{~N}, \mathrm{R} 99 \mathrm{~W}, \\
\text { Sec } 1\end{array}$ \\
\hline 8 & IV & 17 & $\begin{array}{l}\text { Uranium Pit in } \mathrm{T} 137 \mathrm{~N}, \mathrm{R} 100 \mathrm{~W} \text {, } \\
\text { Sec } 2\end{array}$ \\
\hline 9 & -- & 20 & $\begin{array}{l}\text { Uranium Pit in } \mathrm{T} 137 \mathrm{~N}, \mathrm{R} 100 \mathrm{~W} \text {, } \\
\text { Sec } 5\end{array}$ \\
\hline 10 & -- & 20 & $\begin{array}{l}\text { Uranium Pit in T } 137 \mathrm{~N}, \mathrm{R} 100 \mathrm{~W} \text {, } \\
\text { Sec } 5\end{array}$ \\
\hline 11 & - & 21 & $\begin{array}{l}\text { Uranium Pit in T } 137 \mathrm{~N}, \mathrm{R} 100 \mathrm{~W} \text {, } \\
\text { Sec } 6\end{array}$ \\
\hline 12 & -- & 22 & $\begin{array}{l}\text { Uranium Pit in } \mathrm{T} 137 \mathrm{~N}, \mathrm{R} 101 \mathrm{~W}, \\
\text { Sec } 1\end{array}$ \\
\hline
\end{tabular}




\section{CHAPTER 8 REFERENCES}

1. "Little Missouri National Grasslands, North Dakota, Fifth Principal Meridian"; U.S. Department of Agriculture, Forest Service; 1974. 


\section{CHAPTER 9}

REMEDIAL ACTIONS AND COST-BENEFIT ANALYSES 
CHAPTER 9

\section{REMEDIAL ACTIONS AND COST-BENEFIT ANALYSES}

This chapter concerns remedial action cost estimates and cost-benefit analyses for various remedial action options. The alternatives presented are those considered to be the most realistic and practical when evaluated with regard to the present technology, equipment, and transportation facilities available. Remedial measures for the site are divided into two basic categories:

(a) Stabilization at the former Belfield lignite ashing site (Option I)

(b) Removal of the contamination, and stabilization at alternative disposal sites (Options II, III, and IV).

The procedures for decontaminating inactive millsites have not been well established. Although remedial action criteria have been tentatively established, the methodology of satisfying such standards is still in a state of change. The position has been taken that radiological and industrial safety should be pursued to the extent necessary to satisfy remedial action criteria and to provide assurance to the public and to workers. The public should feel comfortable with the methodologies used.

Since each state where tailings (including radium-bearing lignite ash) are located must participate in funding for remedial action, it is fair to assume that there will be strong pressures to assure that costs will be limited to a moderate total.

Remedial actions designed to meet the EPA interim remedial action criteria were investigated. Three possible disposal sites, identified in Chapter 8, were evaluated in terms of the cost of disposal. Although each alternative disposal site has specific and unique characteristics that were considered in estimating costs, care must be exercised in the use of these site-specific cost estimates. There are insufficient data and information to characterize the sites completely for estimating site development costs.

The process of obtaining the necessary permits and the associated costs are considered to be included in the various agency budgets and are not included in this report. Similarly, the contaminated site, the proposed disposal sites, and related gravel or clay material borrow pits have been treated as public lands with no acquisition costs included. 
Costs for future maintenance and radiological monitoring at the location of the contaminated material are not included in this estimate. Funding for such future costs is assumed to come from separate contracts administered by the Federal Government.

On-site stabilization of the contaminated materials (option I) requires that the windblown and Belfield site areas be cleaned up. A 3-m-deep pit would be excavated and all contaminated materials would be placed in the pit and covered with the material obtained from the excavation to a depth of $3 \mathrm{~m}$.

The options for disposal at the alternative sites would provide for the relocation of all debris and contaminated materials from the Belfield site and windblown areas. Thus, in all of the disposal options, the entire site and surrounding areas would be left free of any contaminated materials in excess of the proposed limit of $5 \mathrm{pCi} / \mathrm{g}$ of $226_{\mathrm{Ra}}$ above background. The area to be decontaminated at the Belfield site is shown in Figure 9-1. The depths to which the soil should be removed in each area of Figure 9-1 was estimated from the results of gamma logging of the auger holes drilled on site, as explained in Paragraph 3.4.5.

A discussion of the concepts involved in stabilization of the ash and contaminated material and their applicability to the Belfield site has been detailed in Chapter 6 . It is assumed that vegetation will be planted or a riprap cap provided if the ash is stabilized on site. For options II, III, and IV, a riprap cap of $0.3 \mathrm{~m}$ on top of $3-\mathrm{m}$ cover material is assumed to suffice for erosion control in lieu of vegetation.

\subsection{STABILIZATION OF THE CONTAMINATED MATERIALS ON SITE WITH A 3-METER COVER (OPTION I)}

In this section, the conceptual design of the option to stabilize the Belfield contaminated material is discussed, and the estimated cost of the remedial actions presented.

\section{1 .1 Conceptual Design}

A 3-m-deep pit covering approximately 3.5 acres would be excavated on the Belfield site. The entire site and windblown contaminated areas would be cleaned up and the resulting contaminated materials would be deposited in the excavated pit. The L.P. Anderson Building and the cenex Building would be decontaminated or demolished and replaced; the storage building and well building on site would be demolished and the rubble placed in the pit. An average of $6 \mathrm{in}$. of soil would be removed from the windblown areas, and from 6 in. to 5 ft of soil would be removed from the site proper. The extent of required decontamination at the Belfield site and windblown area is shown in Figure 9-1. All areas would be backfilled to natural grade and landscaped to be similar to original conditions. 
After depositing the contaminated materials in the pit, the pit would be covered with the $3-m$ depth of cover material that was excavated. This thickness of cover material may be sufficient to reduce radon exhalation flux to less than $2 \mathrm{pCi} / \mathrm{m}^{2}-\mathrm{s}$. If additional low-permeability soils for cover material were necessary, most of the surrounding countryside consists of loamy to clayey soils that could be used.

The final shape of the stabilization cover would be flat on top with gently sloping sides. The height of the stabilized pile would be about lo ft above natural grade.

The newly stabilized area would be either covered with $0.3 \mathrm{~m}$ of riprap or seeded with self-regenerating vegetation, native to the area. This vegetation would be able to survive the summer months without irrigation after an initial establishment period of at least one summer season.

If the Belfield site were to be stabilized in place, it would have limited future use.

\section{1 .2 Costs}

As shown in Table 9-1, the cost for stabilization at the Belfield site is estimated to be $\$ 1,500,000$. Costs include cleaning up of the windblown contamination and on-site areas, excavating the deposition pit, depositing the contaminated materials in the pit, covering the materials with a 3-m-depth of cover, contouring the surface, establishing vegetation, and reclaiming all areas.

\subsection{REMOVAL OF THE CONTAMINATED MATERIALS FROM THE SITE (OPTIONS II THROUGH IV)}

Options II through IV would require the complete removal of all contaminated ash, soil, material, and rubble from the Belfield site and windblown areas to a disposal site. The L.P. Anderson Building and the Cenex Building would be decontaminated or demolished and replaced. The storage building and the well building on the site would be demolished and the rubble also would be removed to the disposal site. The amount of soil to be removed during cleanup would depend on the depth of contamination.

Figure 9-1 shows the extent of decontamination required at the Belfield site and shows the assumed average depths of soil removal from the site and windblown areas. An average of $6 \mathrm{in}$. Of soil would be scraped from the windblown areas, and from 6 in. to 5 ft of soil would be removed from various areas of the site. It is estimated that the removal of this amount of soil would reduce the residual radium concentration to less than $5 \mathrm{pCi} / \mathrm{g}$ above background levels. Finally, the site and windblown area would be backfilled to natural grade and released for unrestricted use. 
9.2.1 Excavation and Loading of Contaminated Materials and

Soils

Based upon site examination, a review of the limited data portraying the physical properties of the contaminated soil, and discussions with earthmoving contractors in the area, it appears that there would be no difficulty in removing the contaminated materials from the site. The contractor performing this work would be able to use any number of conventional loading methods, e.g., front-end tractor loaders or conveyor belt feed to overhead loading. Since the water table in the area is reported to be $40 \mathrm{ft}$ below the surface, a system for dewatering the contaminated soil during excavation is not required. There is ample room on site for fast loading and for easy truck ingress and egress.

To eliminate further dispersion of the contamination during loading and transportation operations, dust control equipment and washdown facilities would be provided to counteract the lack of soil moisture during certain seasons of the year.

The decontaminated site and windblown area would be backfilled to natural grade. Local material, all of which must be hauled onto the site, would be used as backfill. No special treatments of the final surface other than establishing native grass cover at the decontaminated Belfield site are considered in this assessment.

\subsubsection{Transportation of the Materials}

Because of inefficiencies for short rail hauls and of the unavailability of railroad tracks near the disposal sites considered, truck transportation is used in all disposal options (Options II through IV).

The use of conveyors and slurry pipeline technology in transporting the contaminated materials has been investigated briefly to assess its viability. While any conclusive statement is very dependent on the site- and route-specific parameters, some generalizations can be made about the viability of conveyors and slurry pipeline in this application:

(a) The longer the life of the project, the more attractive the use of conveyors becomes.

(b) The greater the mass to be moved, the more attractive the use of conveyors becomes.

(c) Conveyors can be more attractive in difficult terrain.

The amount of contamination to be moved at the Belfield site is relatively small and the terrain is basically flat. Therefore, the use of conveyors for this project appears 
uneconomical. There are also many complications involved in the use of conveyors, many of which are difficult to quantify. Public acceptance, acquisition of rights-of-way and permits within a reasonable time-frame, and environmental impact are considerations that cloud the evaluation of conveyors and slurry pipelines.

With all of the factors considered, it appears that truck transportation of contaminated materials is generally preferable to conveyors or slurry pipelines. When a specific site has been chosen, a detailed evaluation would disclose whether this generalization holds true for the selected site and routes.

Truck transportation is considered the most economical means of hauling materials to the disposal sites. If trucks could move the materials at the rate of about 1,000 tons/day, working 5 days/wk, all materials could be removed in about 5 mo. This method assumes the use of conventional truck and/or truck-trailer combinations. Contamination control measures, such as covers and washdown facilities for the trucks, are included as capital costs associated with transportation. No costs are included for repair and maintenance of public roads, since it is assumed that legal load limits will not be exceeded and that the state gasoline taxes will provide the needed revenues for such repair and maintenance.

\subsubsection{Disposal at Alternative Sites}

A discussion of proposed disposal sites is given in Chapter 8. Each disposal site has different physical, geological, and hydrological characteristics. However, because the Federal Government, with input from the state, is ultimately responsible for the selection of disposal sites, there is no assurance that any of the disposal sites considered in this report will be selected. Nevertheless, an effort has been made to quantify those differences based on what limited data for each site were available and to show the costs that would result if the contaminated materials were actually disposed of at the sites discussed in Chapter 8 .

All of the disposal sites considered are old uranium pits or scoria pits within a 17-mi radius of the Belfield site. All are accessible by a combination of paved and gravel roads. Since the sides of these pits are sandstone, it would be desirable to line them with a clay or synthetic liner. The disposal sites selected can be isolated from drainage basins naturally or by dikes and drainage ditches.

The procedure for depositing the contaminated materials would involve lining the pit with a clay or synthetic liner, placing the contaminated materials from the site and windblown areas in the pit, and covering the contamination with cover materials to a depth of at least $3 \mathrm{~m}$. A protective cap of 
$0.3 \mathrm{~m}$ of gravel also would be provided. The stabilized disposal site would be gently sloped and contoured to minimize the potential for water erosion. Sources of cover materials are discussed in Paragraph 8.2 and in the description of each disposal site in Chapter 8.

The costs of all disposal options are shown in Table 9-1, along with those of option I. The sites associated with the various options are as follows:

$$
\begin{aligned}
\text { Option II - } & \text { Site 3, a uranium pit located in } \\
& \text { Section } 6 \text { of Township } 140 \text { North, Range } \\
& 99 \text { West, described in Paragraph } 8.2 .1 . \\
\text { Option III - } & \text { Site 7, a scoria pit located in Section } 1 \\
& \text { of Township } 139 \text { North, Range } 99 \text { west, } \\
& \text { described in Paragraph } 8.2 .2 .
\end{aligned}
$$

Option IV - Site 8, a uranium pit located in Section 2 of Township 137 North, Range 100 West, described in Paragraph 8.2.3.

The costs for disposal range from about $\$ 2,200,000$ for Options II and III to about $\$ 2,500,000$ for Option IV. The haul costs are major components of the total costs and are largely dependent on the distances of the disposal sites from the Belfield site and from the cover material sources.

There are also differences among capital costs associated with transportation and disposal site costs. These differences are attributable to varying requirements for upgrading the access to disposal sites, for preparing the site, and for protecting the disposed materials from erosion by means of diking, clay or synthetic liners, etc.

In Options II through IV the estimated costs include: cleanup of windblown contamination, decontamination of the site, backfilling all affected areas with clean fill, establishing vegetative cover at and around the Belfield site, hauling all contaminated materials to the disposal site, covering the materials at the disposal site with a 3-m depth of cover material, contouring the stabilized disposal site, and placing a $0.3-m$-deep gravel cap for erosion control.

\subsection{ANALYSES OF COSTS AND BENEFITS}

\section{3 .1 Health Benefits}

Each of the remedial action alternatives considered in this chapter has an associated health benefit that would be experienced as a result of the remedial action. This health benefit is the reduction of the health effects (number of lung cancer cases) resulting from the remedial action. 
In Chapter 3 the number of health effects was estimated for the Belfield site in its present condition. To estimate the number of health benefits attributable to particular remedial actions, the effects of those remedial actions on radon exhalation from the ash must be determined, because the health effects calculated in Chapter 3 were associated with radon daughters. While there are some benefits associated with actions such as fencing, these have not been quantified in this assessment of health benefits.

In this evaluation, the health benefit of each option is calculated from the reduction in radon exhalation that is expected for that option. Consequently, radon fluxes were assumed to be reduced from their predicted values under present conditions (as conservatively estimated in Paragraph 3.6.2) to less than $2 \mathrm{pCi} / \mathrm{m}^{2}-\mathrm{s}$ for option I. In Options II, III, and IV, radon flux was assumed to be reduced to zero by the removal of the ash. Since health effects among the population surrounding the site are proportional to radon flux, the present health effects rate was estimated to be reduced by 998 with stabilization in-place and by 1008 with removal of the ash.

Should the benefit (reduction of risk) among on-site workers be considered in this evaluation, it would appear to be about twice as large, since the excess risk from external gamma exposure is of a magnitude comparable to that of radon among the population surrounding the site.

The potential cancer cases avoided (health benefits) for each option are given as a function of time in part $A$ of Table 9-2. The cost per potential cancer case avoided for each option is included as part $B$ in Table 9-2.

As an alternative to the presentation in Table 9-2, the number of potential cancer cases avoided per million dollars expended was calculated and plotted in Figure 9-2. Option I yields the maximum health benefit per unit cost, whereas Option IV yields the minimum benefit per unit cost.

\subsubsection{Land Value Benefits}

The presence of the contamination at the Belfield site has had very little influence on the use or the value of the site or the surrounding land. Presently, there are no pressures to develop the site for other uses, and even though the site is located adjacent to a railroad, it appears likely that no such pressures will develop, at least in the immediate future. Very little industrial development is expected to occur at Belfield, since most industries would rather locate in Dickinson, the economic center of the area.

Under Option I the contaminated material would be stabilized on the present site and the site would continue to have limited use. The value of the site and surrounding land would 
increase very little. The increase in land values would be minimal in comparison with the cost of remedial action.

If the tailings were disposed of at an alternate disposal site (options II through IV), the total Belfield site and surrounding area would be available for unlimited use. However, since there are no other planned uses for this land, the corresponding increase in land values as a result of this remedial action would be small in comparison with the cost of remedial action. It is possible that the market value of the Belfield site could increase from $\$ 80,000$ ( $\$ 10,000 /$ acre) to $\$ 120,000$ ( $\$ 15,000 /$ acre), because it is adjacent to the railroad and could have commercial or light industrial applications.

The value of the surrounding land is not depressed by the presence of the contamination at the site and probably would not change as a result of any remedial action at the site. 
(4)

ASSUME DEPTHS OF REMOVAL

5FT OF MATERIAL TO BE REMOVED

4 FT OF MATERIAL TO BE REMOVED

III 2 FT OF MATERIAL TO BE REMOVED

1 FT OF MATERIAL TO BE REMOVED

6 IN. OF MATERIAL TO BE REMOVED

LEGEND

$-x-x-$ FENCE

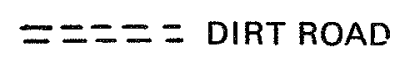

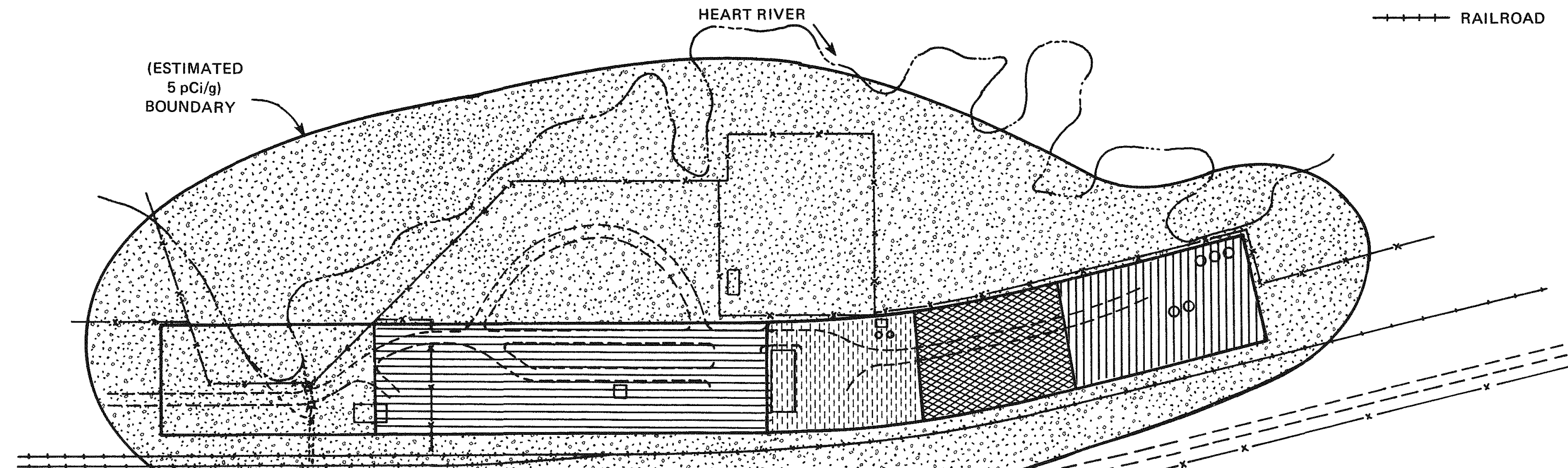

BURLINGTON NORTHERN RR

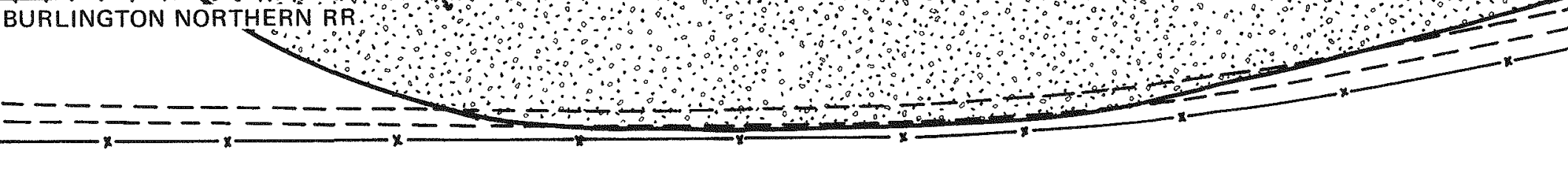

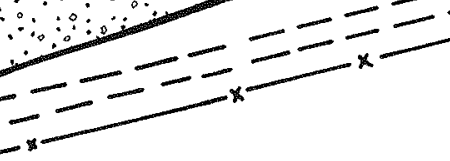

$\underset{\text { SCALE }}{100 \quad 200 \quad 300 \quad 400 \mathrm{FT}}$ 


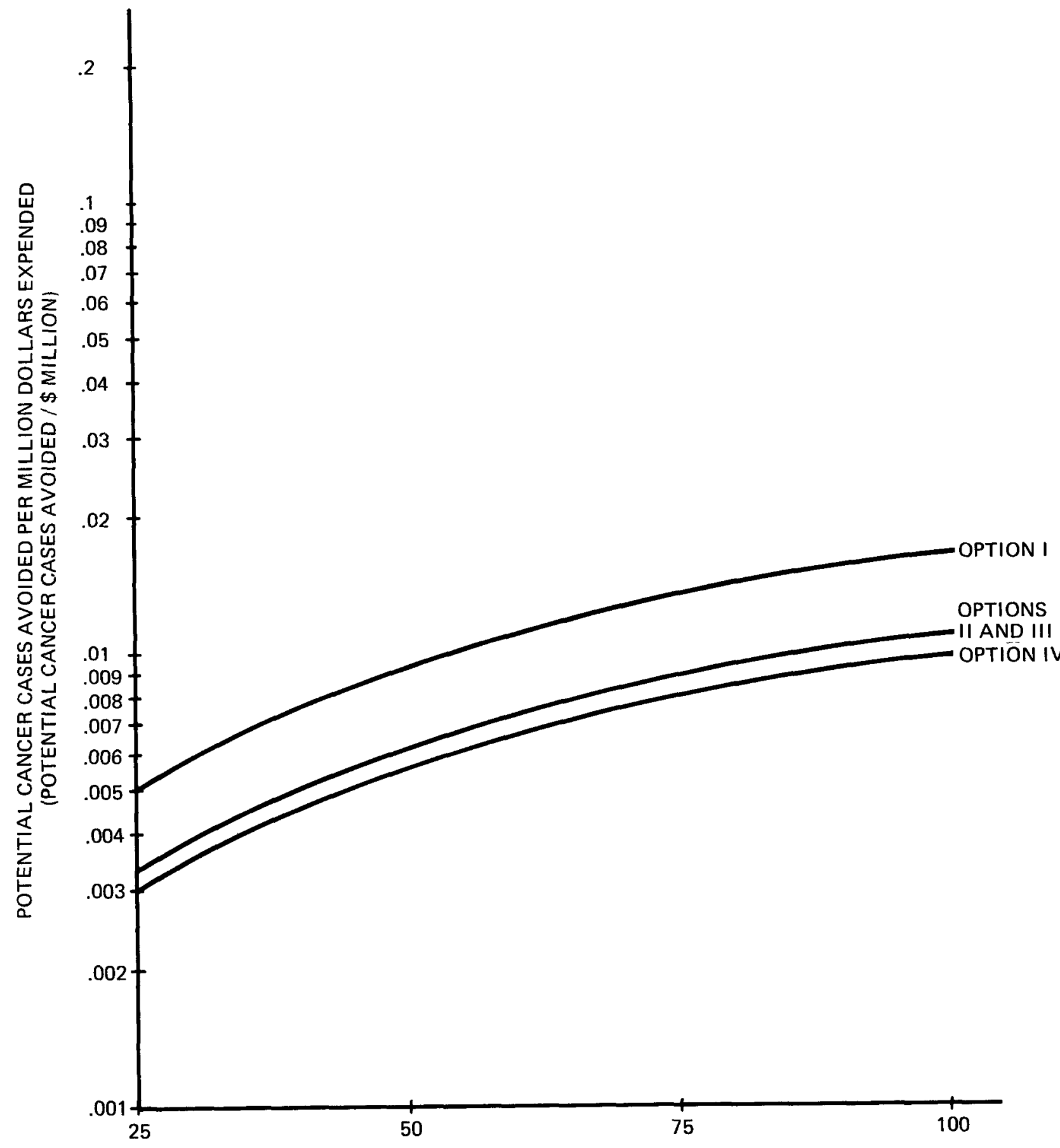

YEARS AFTER REMEDIAL ACTION

FIGURE 9-2. POTENTIAL CANCER CASES AVOIDED PER MILLION DOLLARS EXPENDED 
TABLE 9-1

SUMMARY OF STABILIZATION AND DISPOSAL COSTS ${ }^{a}$

\begin{tabular}{|c|c|c|c|c|c|}
\hline & & \multicolumn{4}{|c|}{ Options } \\
\hline & & I & II & III & IV \\
\hline 1 . & Belfield site Costs & 0.6 & 0.4 & 0.4 & 0.4 \\
\hline 2 . & Off-Site Remedial Action & -- & -- & -- & -- \\
\hline 3 . & $\begin{array}{l}\text { Windblown Area Remedial } \\
\text { Action }\end{array}$ & 0.3 & 0.3 & 0.3 & 0.3 \\
\hline \multirow[t]{2}{*}{4 . } & \multicolumn{5}{|l|}{ Transportation } \\
\hline & $\begin{array}{l}\text { a. Capital Costs } \\
\text { b. Haul Costs }\end{array}$ & -- & $\begin{array}{l}0.1 \\
0.1\end{array}$ & $\begin{array}{l}0.1 \\
0.1\end{array}$ & $\begin{array}{l}0.2 \\
0.2\end{array}$ \\
\hline 5 . & Disposal Site & -- & 0.4 & 0.4 & 0.4 \\
\hline 6. & $\begin{array}{l}\text { Total Cleanup } \\
\text { (sum of lines } 1 \text { through } 5 \text { ) }\end{array}$ & 0.9 & 1.4 & 1.3 & 1.5 \\
\hline & $\begin{array}{l}\text { Engineering, Design, and } \\
\text { Construction Management } \\
\text { ( } 308 \text { of the difference } \\
\text { between lines } 6 \text { and } 4 \mathrm{~b} \text { ) }\end{array}$ & 0.3 & 0.4 & 0.4 & 0.4 \\
\hline & $\begin{array}{l}\text { Total }{ }^{b} \\
(\text { sum of lines } 6 \text { and } 7)\end{array}$ & 1.2 & 1.7 & 1.7 & 1.9 \\
\hline & $\begin{array}{l}\text { Contingency } \\
(30 \% \text { of line } 8)\end{array}$ & 0.3 & 0.5 & 0.5 & 0.6 \\
\hline 10 & $\begin{array}{l}\text { GRAND TOTAL } \\
\text { (sum of lines } 8 \text { and } 9 \text { ) }\end{array}$ & 1.5 & 2.2 & 2.2 & 2.5 \\
\hline $\mathrm{b}_{\mathrm{TO}}$ & $\begin{array}{l}\text { ts are in millions of year } \\
\text { als may differ from the sum } \\
\text { nd-off. }\end{array}$ & cost & or & beca & of \\
\hline
\end{tabular}


TABLE 9-2

POTENTIAL CANCER CASES AVOIDED

AND COST PER POTENTIAL CASE AVOIDED

\section{A. Number of Potential Cancer Cases Avoided}

\begin{tabular}{|c|c|c|c|c|}
\hline Options: & I & II & I I I & IV \\
\hline $\begin{array}{l}\text { Option cost } \\
(\text { million } \$)\end{array}$ & 1.5 & 2.2 & 2.2 & 2.5 \\
\hline $\begin{array}{c}\text { Years After } \\
\text { Remedial } \\
\text { Action }\end{array}$ & & & & \\
\hline $\begin{array}{r}25 \\
50 \\
75 \\
100\end{array}$ & $\begin{array}{l}<0.0075 \\
<0.013 \\
<0.019 \\
<0.024\end{array}$ & $\begin{array}{l}0.0075 \\
0.013 \\
0.019 \\
0.024\end{array}$ & $\begin{array}{l}0.0075 \\
0.013 \\
0.019 \\
0.024\end{array}$ & $\begin{array}{l}0.0075 \\
0.013 \\
0.019 \\
0.024\end{array}$ \\
\hline
\end{tabular}

B. Cost Per Potential Cancer Case Avoided (Million \$)

\begin{tabular}{lcccc}
$\begin{array}{l}\text { Options: } \\
\begin{array}{c}\text { Option Cost } \\
(\text { milition } \$)\end{array}\end{array}$ & I & II & III & IV \\
$\begin{array}{c}\text { Years After } \\
\text { Remedial } \\
\text { Action }\end{array}$ & 1.5 & 2.2 & 2.2 & 2.5 \\
& & & & \\
25 & $>200$ & 290 & 290 & 330 \\
50 & $>120$ & 170 & 170 & 190 \\
75 & $>80$ & 120 & 120 & 130 \\
100 & $>60$ & 90 & 90 & 100 \\
\hline \hline
\end{tabular}


GLOSSARY 
absorbed dose

$A-\mathrm{E}$

AEC

alpha particle $(\alpha)$

amenability

anomaly

(mobile gamma survey)

aquifer

atmospheric pressure
Radiation energy absorbed per unit mass.

Architect-Engineer.

Atomic Energy Commission.

A positively charged particle emitted from certain radioactive materials. It consists of two protons and two neutrons, hence is identical with the nucleus of the helium atom. It is the least penetrating of the common radiations $(\alpha, \beta, \gamma)$, hence is not dangerous unless alpha-emitting substances have entered the body.

The relative ease with which a mineral can be removed from an ore by a particular process.

Any location detected by the mobile gamma survey where the recorded counts per second (c/s) from the large gamna-ray detector exceed the determined background for that area by 50 or more $\mathrm{c} / \mathrm{s}$.

A water-bearing formation below the surface of the earth; the source of wells. A confined aquifer is overlain by relatively impermeable rock. An unconfined aquifer is one associated with the water table.

Pressure exerted on the earth by the nass of the atmosphere surrounding tne earth; expressed in incnes of mercury (at sea level and $0^{\circ} \mathrm{C}$, standará pressure is 29.921 in. H(j). 
background radiation

beta particle ( $B$ )

BEIR

BUM (USBOIY)

CHES

Curie (Ci)

daughter product

diurnal

dose equivalent

EPA (USEPA)

ERDA (USERDA)
Naturally occurring low-level radiation to which all life is exposed. Background radiation levels vary from place to place on the eartn.

A particle emitted from some atoms undergoing radioactive decay. A neyatively charged beta particle is identical to an electron. A positively charged beta particle is called a positron. Beta radiation can cause skin burns and beta emitters are harmful if they enter the body.

Biological Effects of Ionizing Radiation.

Bureau of Mines.

Center for Health and Environmental Studies, Brigham Young University, Provo, Utah.

The unit of radioactivity of any nuclide, defined as precisely equal to $3.7 \times 10^{10}$ disinteyrations/second.

The nuclide remaining after a radioactive decay. A daughter atom may itself be radioactive, producing further daughter products.

Daily, cyclic (happening each day or during the day).

A tern used to express the amount of effective radiation when modifying factors have been considered ( $t$ he numerical product of absorbed dose and quality factor).

Environmental Protection Agency. Energy Research and Development Aăministration. 
ERDA-GJO

ery

external yamma radiation ( $\mathrm{EGR}$ )

exposure

exhalation

$F B \& D U$

fixed alpha

gamma background

gamma ray $(\gamma)$
Energy Research and Development Aduinistration-Grand Junction Office.

A basic unit of work or energy in the centimeter-gran-second syster ( 1 erg $=7.4 \times 10^{-8}$ ft-10, or $10^{-7}$ joule).

Gamma radiation emitted from a source(s) external to the body, as opposed to internal gamma radiation emitted from ingested or inhaled sources.

Related to electrical charge produced in air by ionizing radiation per unit mass of air.

Emission of radon from earth (usually thought of as coming from a uraniurn tailings pile, but actually from any location).

Ford, Bacon \& Davis Utan Inc.

Particulate alpha emitting isotopes which have become imbedded in otherwise nonradioactive surfaces and which cannot be removed by standard decontamination techniques.

Natural gamma ray activity everywhere present, originating from two sources: (1) cosmic radiation, bombarding the earth's atmosphere continually, and (2) terrestrial radiation. whole body absorbed dose equivalent in tne U.S. due to natural gamma background ranges from about 60 to about $125 \mathrm{mrem} / \mathrm{yr}$.

High energy electromagnetic radiation emitted from the nucleus of a radioactive atom, with specific energies for the atoms of different elements and having high penetrating power. Grand Junction Office. 
ground water

health effect

heap leaching

HE'W (USHEW)

insult

Interim Primary Drinking Water Regulations

iso-exposure Iine

isotope

JCAE

knot

man-rem (person-rem)
Subsurface water in the zone of full saturation which supplies wells and springs.

Adverse physiological response from tailings (in this report, one health effect is defined as one case of cancer from exposure to radioactivity).

A process for removing uranium from ore, tailings, or other material wherein tne material is placed on an impermeable pad and wetted with appropriate reagents. The uranium solution is collected for further processing.

Departinent of Health, Education, and welfare.

Negative impact on the environment or the health of individuals.

Title No. 40 of the code of Federal Regulations, Chapter 1 , Part 141, dated Dec 24, 1975 and effective June 24, 1977 .

A line drawn on a map to connect a set of points having the same exposure rate.

One of two or more species of atoms witn the same atomic numbers (the same chemical element) but with different atomic weights. Isotopes usually nave very nearly the same chemical properties, but somewhat different physical properties.

Joint Committee on Atomic Energy.

A unit of velocity, approximately equal to $1.15 \mathrm{mi} / \mathrm{hr}$.

A unit used in nealth physics to compare the effects of different amounts of radiation on groups 
$\mu \mathrm{R} / \mathrm{hr}$
$\mathrm{mR} / \mathrm{hr}$
$\mathrm{MeV}$
maximum pernissible
concentration (MPC)

NAS

NIOSH

noble gas

NRC

nuclide

ORNL

ORP-LVF (EPA)

$\mathrm{pCi} / 1$

$\mathrm{pCi} / \mathrm{g}$

$\mathrm{pCi} / \mathrm{m}^{2}-\mathrm{s}$ of people. It is obtained by suming individual dose equivalent values for all people in the population.

ivicroroentgen per hour $\left(10^{-6}\right.$ $\mathrm{R} / \mathrm{hr}$ ).

Miliroentgen per hour $\left(10^{-3}\right.$ $\mathrm{R} / \mathrm{hr}$ ).

Million electron volts.

The highest concentration in air or water of a particular radionuclide permissible for occupational or general exposure without taking steps to reduce exposure.

National Academy of Sciences.

National Institute for Occupational safety and Health.

One of the gases, such as helium, neon, radon, etc., with completely filled electron shells, which is therefore chemically inert.

Nuclear Regulatory Commission.

A general terrn applicable to all atomic forms of the elements; nuclides comprise all the isotopic forms of all the elements. Nuclides are distinguished by their atomic number, atomic mass, and energy state.

Oak Ridge National Laboratory.

Office of Radiation Programs, Las Vegas Facility (Environmental Protection Agency).

Picocurie per liter $\left(10^{-12} \mathrm{Ci} / 1\right)$

Picocurie per gram $\left(10^{-12} \mathrm{Ci} / \mathrm{g}\right)$

Picocurie per square meter per second $\left(10^{-12} \mathrm{Ci} / \mathrm{m}^{2}-\mathrm{s}\right)$ 


\section{PHS (USPIS)}

quality factor (QF)

rad

rađioactivity

radioactive decay chain

radium

radon

radion background
Puolic Health service.

An assigned factor that denotes the nodification of the effectiveness of a given absorbed dose by the linear eneryy transfer.

The vasic unit of absorbed dose of ionizing radiation. A dose of 1 rad means the absorption of 100 erys of radiation energy per yrain of absorbiny material.

The spontaneous decay or disintegration of an unstable atomic nucleus, usually accornpanied by the emission of ionizing radiation.

A succession of nuclides, each of wnich transforms by radioactive disintegration into the next until a stable nuclide results. The first member is called the parent, the intermediate members are called uaugnters, and the final stable member is called the end product.

A radioactive element, chemically similar to Darium, formed as a daughter product of uranium $(238 \mathrm{U})$. The most common isotope of radium, $226_{\mathrm{Ra}}$, nas a halflife of 1,620 yr. Radium is present in all uranium-bearing ores. Trace quantities of both uranium and radium are found in all areas, contributing to the background radiation.

A radioactive, chemically inert gas. The nuclide $222 \mathrm{Rn}$ has a half-life of 3.8 days and is formed as a daughter product of radium (226 $\mathrm{Ra})$

Low levels of radon gas found in air resulting from the decay of naturally occurring radiurn in the soil. 
radon concentration

rauun ciausnter

radon daughter concentration (RDC)

racion flux

rafínate

recharge

relin

(roentgen equivalent wan)
The amount of radon per unit volume. In this assessment, the average value for a 24-hr period of atmospheric radon concentrations, determined by collecting data for edch 30-min period ot a 24-hr day and averaying these values.

Jie of several short-lived radioactive daughter products of radon (several of the dauyhters enit alpha particles).

The concentration in air of sncrt-lived radon daughters, expressed either in pci/l or in terins of working level (ivL).

The quantity of radon emitted from a surface in a unit tine per unit area (typical units are in $\left.\mathrm{pui} / \mathrm{r}^{2}-\mathrm{s}\right)$.

The liquid part remaining after a product has been extracted in a solvent extraction process.

The processes by whicn water is ausorbed and added to tine zone of saturation of an aquifer, eitner directly into the formation or indirectly by way of another formation.

ihe unit of dose equivalent of any ionizing radiation which prouluces the salne biological effect as a unit of absorbed dose of ordinary $x$-rays, nullerically equal to the absorbed dose in rads multiplied by the appropriate quality factor for the type of radiation. The rem is the basic recorded urit of accumulated dose to personnel.

'The value of minerals in tailings material. 
riprap

roentgen $(R)$

sands

scintillometer

slimes

tailings

UIM'TKA

working level (WL)
An irregular protective layer of broken rock.

A unit of exposure to ionizing radiation. It is that amount of yaunina or $x$-rays required to produce ions carrying 1 electrostatic unit of electrical charye, eitner positive or negative, in 1 cubic centimeter of dry air under standard conaitions, numerically equal to $2.58 \times 10^{-4}$ coulombs $/ \mathrm{kg}$ of air.

Relatively coarse-grained materials produced along with the slimes as waste products of ore processing in uranium mills (see tailings). These sands norinally contain a lower concentration of radioactive material than the slimes.

A yamu-ray detection instrument normally utiliziny a lvaI crystal.

Extremely fine-grained naterials inixed witn small amounts of water, produced along with the sands as waste products of ore processing in uranium mills (see tailings). The highest concentration of radiodctive naterial remaining in tailings is found in the slimes.

The remaining portion of a metal-bearing ore after the desired metal, such as uranium, has been extracted. Tailings also may contain other minerals or metals not extracted in the process (e.g., radium).

Uraniuin Mill 'railings Kenedial Action

A unit of radon daughter exposure, equal to any combination of short-lived radon daughters in 1 liter of air that will result in the ultimate 
emission of $1.3 \times 10^{5}$ liev of potential alpha energy. This level is equivalent to the energy prouuced in the decay of the daughter products RaA, RaB, $\mathrm{RaC}$, and $\mathrm{RaC}^{\prime}$ that are present under equilibriun conditions in a liter of air containing $100 \mathrm{NCi}$ of $\mathrm{Rn}-222$. It does not incluae decay of RaD (22-yr half-life) and subsequent daughter products.

working level month (WLil)

One WLM is equal to the exposure received from 170 wL-hours. 